\title{
PRESIDENCIALISMO Y REFORMA DEL ESTADO: CAMBIOS Y PERSISTENCIAS EN EL SISTEMA POLITICO MEXICANO
}

FEBNANDO PÉREZ CORREA Coordinador 


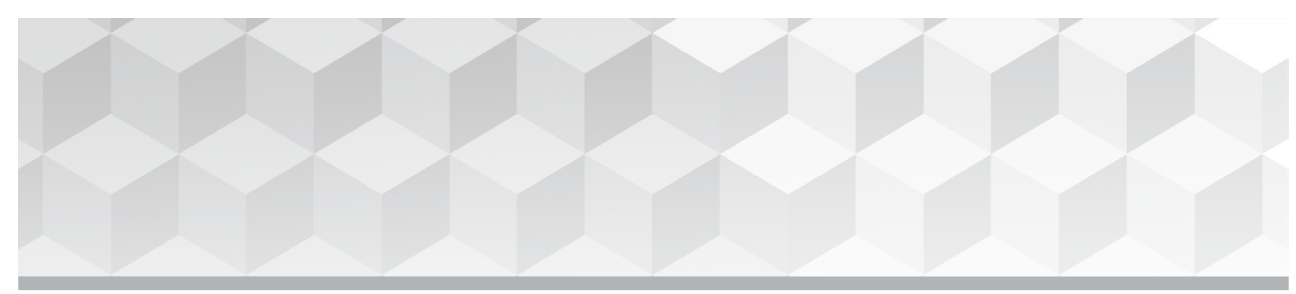

\section{UNIVERSIDAD NACIONAL AUTÓNOMA DE MÉXICO}

Rector • Enrique Luis Graue Wiechers

Secretario General • Leonardo Lomelí Vanegas

Secretario Administrativo • Leopoldo Silva Gutiérrez

Abogada General • Mónica González Contró

Director General de Publicaciones y Fomento Editorial • Joaquín Díez-Canedo

\section{FACULTAD DE CIENCIAS POLIITICAS Y SOCIALES}

Directora • María Angélica Cuéllar Vázquez

Secretaria General • Arturo Chávez López

Secretario Administrativo • José Alejandro Santiago Jiménez

Jefa del Departamento de Publicaciones • María Eugenia Campos Cázares
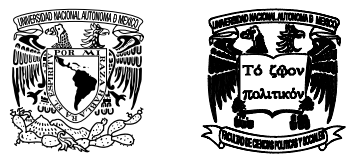

d.gapa 


\section{PRESIDENCIALISMO Y REFORMA DEL ESTADO:}

CAMBIOS Y PERSISTENCIAS EN EL SISTEMA POLÍTICO MEXICANO

FERnANdo PÉREZ CoRreA

Coordinador

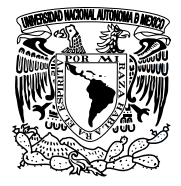

Universidad Nacional Autónoma de México 
Esta investigación, arbitrada a "doble ciego" por especialistas en la materia, se privilegia con el aval de la Facultad de Ciencias Políticas y Sociales, Universidad Nacional Autónoma de México.

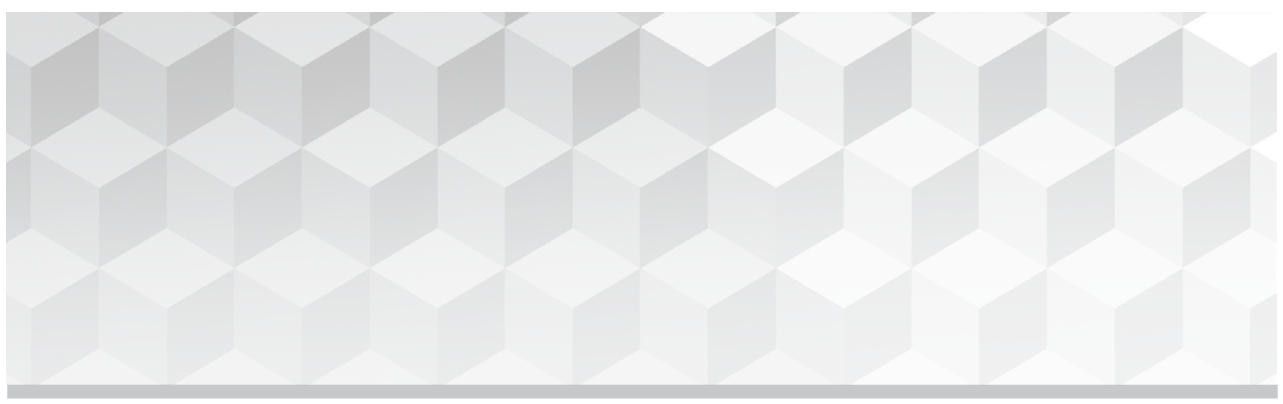

Este libro fue financiado con recursos de la Dirección General de Asuntos del Personal Académico de la Universidad Nacional Autónoma de México, mediante el proyecto "Reforma del Estado y Nuevo Sistema Político Mexicano", parte del Programa de Apoyo a Proyectos de Investigación e Innovación Tecnológica PAPIIT IN303509, Dr. Fernando Pérez Correa Fernandez del Castillo, responsable académico del proyecto.

Presidencialismo y Reforma del Estado: cambios y persistencias en el Sistema Politico Mexicano

Primera edición: 27 de enero, 2017

Reservados todos los derechos conforme a la ley.

D.R. ( $) 2016$ Universidad Nacional Autónoma de México

Ciudad Universitaria, delegación Coyoacán, C.P. 04510, Ciudad de México.

Facultad de Ciencias Políticas y Sociales, Circuito "Maestro Mario de la Cueva" s/n, Ciudad Universitaria, delegación Coyoacán, C.P. 04510, Ciudad de México.

Oficina del Abogado General

Dirección General de Asuntos Jurídicos

ISBN: 978-607-02-8958-3

"Queda prohibida la reproducción parcial o total, directa o indirecta, sin la autorización escrita del titular de los derechos patrimoniales".

Impreso y hecho en México/Made and printed in Mexico 


\section{CONTENIDO}

INTRODUCCIÓN. COMPLEJIDADES DE LA TRANSICIÓN POLÍTICA

EN MÉXICO . . . . . . . . . . . . . . . . . . . . . . . . 7

Fernando Pérez Correa

El PACto POR MÉXico en los CONTORNOS DEl PRESIDENCIALISMO . . . . . . 41 Héctor Zamitiz Gamboa

REForma POlítica, PARIDAd DE GÉNERO EN EL CONGRESO MEXICANO

Y LOS NUEVOS PARÁMETROS DE LA RELACIÓN EJECUTIVO-LEGISLATIVO . . . 61

Gloria Luz Alejandre Ramírez

El CíClOPE PRESIDENTE DE LA DESCOMPOSICIÓN COLECTIVA . . . . . . . . 93 Julio Bracho Carpizo

El PACTO POR MÉXICO: Reformas del ESTAdo . . . . . . . . . . . . . . . 113

César Alejandro Hernández Mendoza

CONSIDERACIONES SOBRE EL CONCEPTO GRUPO DE INTERÉS-PRESIÓN . . . . . 125

Fernando Ayala Blanco 


\title{
INTRODUCCIÓN. \\ COMPLEJIDADES DE LA TRANSICIÓN POLÍTICA EN MÉXICO
}

\section{Fernando Pérez Correa}

\begin{abstract}
1
lo largo de una historia milenaria, el territorio de lo que hoy es México fue recorrido, explorado, ocupado o abandonado por incontables grupos sociales de los más diversos orígenes étnicos, lingüísticos y culturales; enfrentados con frecuencia a los ocupantes; unos, con éxito; y, otros más, echados o sometidos. El territorio fue siempre dispar: selvático, pantanoso, seco, húmedo, seco e incluso desértico; escabroso o llano; de suelos fértiles, arenosos, productivos o yermos; en suma, de clima tórrido o frío; desigual, difícil y codiciado: ofrecía una base propicia y variada para construir y asentar un hogar y ganar el sustento. México se pobló como resultado de tentativas incontables de dichos grupos: algunos de paso, pronto establecidos, consolidados en asentamientos firmes, o apenas refugiados en suelos transitorios; otros más, vencidos como resultado de tentativas fallidas u ocupaciones malogradas; reducidos a la penuria de pueblos en tránsito; en fin, aquellos asentados ya en suelos propicios, nutridos por las raíces de la tierra, ahora propia; en un territorio compartido con otros ocupantes: poblaciones diversas, pluriculturales y con visiones variadas.

Como resultado de procesos hoy distantes, en un planeta ya ocupado y delimitado, México es un Estado-Nación de múltiples pueblos, con una evidente mayoría mestiza, consolidado, cuya variedad de raíces, es fruto de un amplísimo abanico de orígenes y expresiones culturales; conjunto constitutivo de un todo en permanente construcción. Recordemos, además, que a la multiplicidad de grupos étnicos primigenios habría que añadir hoy, cuando menos, la contribución decisiva de la población de origen español. En consecuencia, la cuestión de la gobernabilidad ha sido para México, desde tiempos inmemoriales, un persistente desafío.
\end{abstract}


En efecto, la volatilidad ha estado siempre presente: esto es, lo estuvo en la etapa lítica (33000-5000 a.C.); en el preclásico (2000-150 a.C.); el clásico (150900 d.C.), y el posclásico (900-1521), ${ }^{1}$ periodo que concluye brutalmente con la llegada de los españoles y el cristianismo que se tradujo en la construcción de un nuevo mestizaje, y en la conformación gradual y accidentada del México contemporáneo, como lo acreditan la historia de la Colonia, la Independencia, los siglos XIX, XX y los primeros años del XXI.

El hecho decisivo salta a la vista: la sociedad mexicana ha sido siempre plural, tanto étnica como culturalmente; esto es, diversa en materia de formas, estilos y niveles de vida. Es cierto, México es hoy dependiente de las consecuencias del Tratado de Libre Comercio, concertado con Canadá y Estados Unidos; socio de un trío de talla muy desigual. Ello no impide que más de la mitad de su fuerza de trabajo (57 por ciento) se encuentre en el sector informal (consecuencia y expresión de dicha desigualdad), ni que el país cuente con un complejo edificio de poderes locales y estatales, con las más variadas tramas culturales y capacidades económica, política y social. Ahora bien, la naturaleza misma del régimen ha cambiado, con una Presidencia irresistible a lo largo de décadas,

${ }^{1}$ Tomo la periodización de la historia de México propuesta por Erik Velásquez García en "Los Habitantes Más Antiguos del Actual Territorio Mexicano"; según la cual, la etapa lítica (33,000-5,000 a.C.), aunque según otros autores, como Pablo Escalante Gonzalbo, estiman que el poblamiento de América "se inició alrededor del año 40,000 a.C."; en consecuencia los valores serían 40,000-5,000 a.C. Siguiendo a "la mayor parte de los especialistas mexicanos", Velázquez García nos dice que la etapa lítica se fragmenta en tres periodos: "arqueolítico (33,000-12,000 a.C.), cenolítico temprano (12,000-7,000 a.C.) y cenolítico tardío (7,000-5,000 a.C.)". Conviene decir que "la expresión pictórica más antigua de que se tiene noticia procede de la etapa lítica y se encuentra en la Cueva de "San Bortijas I", en Baja California. El primer periodo se justifica, entre otras evidencias, por la recuperación de un cráneo masculino en Chimalhuacán, Estado de México, con una antigüedad calculada en 33,000 a.C. El periodo lítico concluye con el protoneolítico (5,000-2,500 a.C.), en donde "hubo un paulatino incremento de la población", generándose un nuevo estilo de vida, conocido como "macrobandas estacionales". La etapa en comento finaliza por el surgimiento de "comunidades sedentarias que se sustentaban en patrones de producción (agricultura)". Al terminar este periodo se inicia "el periodo preclásico en Mesoamérica (2,500 a.C.-200 d.C.)". El autor propone un "preclásico temprano" (2,500 a.C.-1,200 a.C.). Un preclásico medio en la región olmeca (1200-400 a.C.) y, simultáneamente, el "preclásico medio en el resto de Mesoamérica" (1200-400 a.C.); y un "preclásico tardío" (400 a.C.-200 a.C.); en fin, el "clásico en el México antiguo" es un periodo estudiado y expuesto por Enrique Nalda, quien lo caracteriza "como un proceso de florecimiento cultural, concentración de la población y colonización de territorios norteños, procesos de urbanización, comercio (intercambio de bienes); en fin, aparición de formas de organización más complejas (el Estado)". Cfr. Nalda, Enrique, "El Clásico en el México Antiguo", en Nueva Historia General de México, México, El Colegio de México, 2010, y Velásquez García, Erik, "Los habitantes más antiguos del actual territorio mexicano", en Nueva Historia General de México. 
el Poder Ejecutivo se encuentra hoy sin el respaldo mayoritario del Congreso, órgano, a su vez, fragmentado y unido apenas por acuerdos, algunos de fondo y muchos más de circunstancia; y sin el apoyo de buena parte de los gobiernos estatales y municipales.

Desde los orígenes ya descritos hasta nuestros días, la gobernabilidad ha sido una tarea apremiante que hoy constituye una cuestión decisiva y un tema crucial de la política: tras décadas reiteradas de reformas políticas, emprendidas apenas cuatro años después de promulgada la Constitución. El artículo 73 constitucional había sido reformado 77 veces a julio de 2016, mientras que a julio de 2015 las reformas al texto mismo ocurrieron 642 veces, como resultado de 229 decretos. ${ }^{2}$ Las reformas buscaron reconciliar al país consigo mismo después de la Revolución, y superar discordias diversas. Se dieron en un contexto de grandes discrepancias en el Congreso hasta 1934 y, con razonables mayorías, a partir de entonces hasta 1997, cuando el partido del Presidente no logró la mayoría absoluta en la Cámara de Diputados. En la actualidad, la Constitución sólo puede ser reformada como resultado del acuerdo de varios partidos políticos. En fin, hoy parece perdurablemente establecido un sistema plural de partidos, fundado en la alternancia y en la asignación del poder a coaliciones mayoritarias. Son varios los ingredientes en obra. En efecto, México cuenta hoy con un verdadero sistema de partidos, así sea frágil y fragmentado; un poder decisorio del Presidente ya disminuido; en el contexto de la creciente emergencia de una constelación de gobiernos locales y estatales, hasta hace poco apenas decorativos; un sistema de partidos, con o sin alianzas para integrar fuerzas hegemónicas, que dan paso inestable a una agenda sin consensos; en fin, con una administración pública compleja, en acción en los tres ámbitos de gobierno, que opera sin un marco idóneo de mecanismos de control del destino de los cuantiosos recursos fiscales destinados al gobierno, la administración, los partidos y, sobre todo, a la gestión de la administración pública, en sus diversos

${ }^{2}$ La Constitución Política de los Estados Unidos Mexicanos ha sido reformada como resultado de iniciativas de los poderes federales y de las legislaturas de los estados, de acuerdo a lo establecido en el artículo 135 constitucional: "La presente Constitución puede ser adicionada o reformada. Para que las adiciones o reformas lleguen a ser parte de la misma, se requiere que el Congreso de la Unión, por el voto de las dos terceras partes de los individuos presentes, acuerden las reformas o adiciones, y que éstas sean aprobadas por la mayoría de las legislaturas de los Estados y de la Ciudad de México." Cfr. Fix-Fierro, Héctor, "Engordando la Constitución", Nexos, febrero de 2014. Disponible en: <http://www.nexos.com. $\mathrm{mx} / \mathrm{p}=18375>$ y Fix-Fierro y Valadés, Diego, "Hacia la reordenación y consolidación del texto de la Constitución Política de los Estados Unidos Mexicanos de 1917. Estudio introductorio". Disponible en: $<$ http://www2.juridicas.unam.mx/constitucion-reordenada-consolidada/files/Estudio_Introductorio.pdf>. 
ámbitos y niveles (poderes federales, estatales o municipales, organismos gubernamentales y organismos autónomos, congresos y judicatura).

Construir un sistema democrático y plural fue una demanda recurrente a lo largo del siglo pasado, aunque ya establecido, hoy dicho sistema ha sido presa, ostensiblemente, de un trazo distintivo de los diversos gobiernos del pasado y el presente: la corrupción, aunque con intensidad y coloraciones diversas, según los órdenes y los niveles de gobierno de que se trate; y según los poderes en cuestión. En fin, en la actualidad, la cuestión de la gobernabilidad democrática, aunque hayan quedado atrás los días de la dominación del partido hegemónico, sigue siendo un objetivo inalcanzado. Cabe también registrar la grave deficiencia que implica hoy, la conformación de un régimen de partidos sin fuerza; esto es, carente de mayorías y mecanismos operativos de concertación incluyente de alianzas parlamentarias, que hagan del Congreso un foro eficaz, capaz tanto de desahogar su propia agenda y de construir compromisos, acuerdos e iniciativas que estructuren su relación con el Ejecutivo y fortalezcan la gestión pública. En ese cuadro, la conformación de un instrumento que impulse la articulación de fuerzas y abra paso a la gobernabilidad, se plantea como una tarea crucial. La confrontación potencial entre el Ejecutivo y el Legislativo pudiera ser la expresión en una grave deficiencia de la estructura constitucional de los poderes federales del país. Para analizar esta cuestión, contrastemos el proceso, acudiendo a un análisis somero de la estructuración de diversas formas de gobernabilidad deficiente, como el presidencialismo con mono partidismo o, en el extremo opuesto: la fragmentación creciente del Congreso y la consiguiente incapacidad de decisión del conjunto; extremos recurrentes, presentes a lo largo de nuestra historia distante y reciente; esto es, desde las primeras tentativas de estructurar un Estado democrático cuya estructuración no conlleve la incapacidad de emprender y alcanzar las tareas nacionales; aunque también, paradójicamente, sin abandonar ni la superación del monopartidismo, ni el compromiso con el pluralismo político, ambas metas recurrentemente registradas por nuestra historia. Acometamos entonces la tarea que el despliegue de este texto y su conclusión reclaman.

\section{La gobernabilidad: fundación e historia antigua}

Conviene recordar, así sea superficialmente, la remota fundación y florecimiento del centro urbano que hoy identificamos como "San Lorenzo" (1500- 
900 a.C.); y más tarde, la creación de otra antigua ciudad fundacional: La Venta (1200-400 a.C.), ${ }^{3}$ ambos centros urbanos primigenios, cuya formación, encumbramiento, decadencia y desaparición ilustran la fuerza y fragilidad de la cohesión social fundacional, los frecuentes desplazamientos geográficos de tribus y poderes y, finalmente, el colapso y abandono del territorio; como habría de ocurrir, más tarde, con el ciclo de establecimiento, autonomía, dominación, decadencia y abandono de otras ciudades, como Teotihuacán (150-750 a.C.), ${ }^{4}$ y como otra gran ciudad, articuladora de pueblos, Cuicuilco, destruida por una devastadora erupción, su población desvanecida y su territorio cubierto por la lava. Otro caso, y el más reciente, el último anterior a la conquista, fue Tenochtitlán, ${ }^{5}$ ciudad que, no obstante su fundación comparativamente tardía, alcanzó una gran influencia cultural en vastos territorios del altiplano. ${ }^{6}$ Tenochtitlán inesperadamente habría de ser presa de la fatalidad,

3 "Durante trescientos años el asentamiento de San Lorenzo fue el centro político de su región, hasta que, en el año 900 a.C., fue abandonado de manera abrupta tras la mutilación y entierro de algunas de sus esculturas. Entre el año 900 y el 500 a.C. florecieron varios sitios en las cercanías, pero ninguno tuvo la magnitud de La Venta, al que podemos ver como el genuino relevo de San Lorenzo. En La Venta se levantó la primera "gran pirámide" de Mesoamérica, un gigantesco cono ondulante de tierra apisonada, rodeado de plazas y pequeñas plataformas." Escalante Gonzalbo, Pablo, "El México antiguo", en Nueva Historia Mínima de México, México, El Colegio de México, 2004, pp. 18-19.

${ }^{4}$ La caída de Teotihuacán fue un proceso marcado por la destrucción, la enfermedad, la huida masiva y la indefensión. La consecuencia fue la disminución masiva de su población: de 150,000 habitantes pasó a tan sólo 30,000. "No se conoce el ritmo al que se produjo esa reducción del número de pobladores, ni la fecha de inicio del proceso; lo que sí se sabe es que simultáneamente, hacia finales del Clásico, comenzó a recuperarse la población de la Cuenca de México y las regiones vecinas, en especial las ubicadas al oriente de esa cuenca, a costa de un éxodo masivo desde Teotihuacán". Existen tres hipótesis sobre el origen de la caída de Teotihuacán: el cambio climático que afectó a las tierras de cultivo; la "estrangulación" de las rutas de comercio por otras comunidades, como Xochicalco; en fin, los problemas internos que resultaron en enfrentamientos entre grupos sociales de diferentes estratos. Cfr. Nalda, Enrique, "El Clásico en el México Antiguo", en Nueva Historia General de México, op. cit.

5 "El rasgo más sobresaliente de Tenochtitlan era su carácter insular. La ciudad creció sobre un suelo artificial de dos tipos: grandes islotes habitacionales, cada uno de los cuales era asiento de un tlaxilacalli o barrio sustituto, y muy delgadas franjas de tierra húmeda y fértil que conocemos como chinampas." Escalante Gonzalbo, Pablo, "El posclásico en Mesoamérica", en Nueva Historia General de México, op. cit., p. 163.

6 "El relato de una larga peregrinación fue conservado por los mexicas como parte de su tradición y origen. Así fundaron la gran Tenochtitlan, en el lago de Texcoco, guiados por su dios Huitzilopochtli. Los mexicas habían salido de una isla llamada Aztlán, por cuyo nombre también son conocidos como aztecas, situada probablemente en algún lugar remoto al norte de Tenochtitlan. Este hecho está documentado, en especial en el códice conocido como la Tira de la Peregrinación, que es una tira de papel de maguey que representa el viaje del pueblo desde su salida de Aztlán. Los historiadores consideran que alrededor de los años 1150 y 1300 los mexicas peregrinaron por diversos lugares hasta asentarse en los 
por el arribo de invasores de otro mundo, portadores de lo desconocido: una lengua nueva y conocimientos, estrategias, prácticas, armas y recursos ignorados por los habitantes de América; cuya presencia hizo de la gran ciudad una fuerza confundida y frágil, desamparada frente a la indescifrable patencia de estos seres, montados sobre desconocidos caballos, dueños del fuego y de la muerte. El redescubrimiento de su propia fuerza llegó a los aztecas cuando era demasiado tarde para defender, menos aún para restaurar, un antiguo orden irreparablemente perdido.

La Ciudad de México se levanta como el testimonio vivo del proceso de formación y colapso de hegemonías, ahora a cargo de nuevos fundadores, indescifrables y avasallantes, listos para dominar la región sobre la base del establecimiento de tiempos nuevos, distintos. ${ }^{7}$

Volvamos a Aztlán. La llegada tardía de los aztecas, ha sido simbólicamente plasmada por su asentamiento, precisamente en el sitio donde, según enseñaba la tradición, se encontraba sobre un nopal, un águila devorando una serpiente. Testimonio análogo nos ofrece, en fin, el relato de su expansión, no sin resistencias, en el Valle de México. Fue un largo proceso. Con el tiempo,

lagos del Valle de México. La mayor parte de las fuentes históricas señalan que la fundación de MéxicoTenochtitlan ocurrió en el año 1325. Esta fecha corresponde a la que declararon los propios indígenas en los años siguientes a la Caída de Tenochtitlan. Los estudios arqueoastronómicos indican que en ese año también ocurrió un eclipse solar, suceso astronómico que pudo ser tomado por los mexicas como un marcador mítico que pudiera sustentar, además, la supuesta relación entre los toltecas y los tenochcas. Huitzilopochtli dijo a su pueblo que fuera hacia nuevas tierras, también les ordenó que dejaran de llamarse aztecas porque a partir de ese momento serían todos mexicanos, así es recreado en el Códice Aubin y el Códice Durán. La Tira de la Peregrinación señala que Aztlán estaba ubicado en una isla donde había seis calpullis (clan formado por un conjunto de familias) y un gran templo, probablemente dedicado a Mixcóatl, después que los mexicas llegaron a Teoculhuacan en el año l-pedernal, partieron ocho calpullis encabezados por cuatro teomamaque (cargadores de los dioses); uno de ellos, identificado como Tezcacóatl, quien "cargaba" a Huitzilopochtli. Según el mito, Huitzilopochtli ordenó que fundaran la ciudad donde estuviera "un águila parada sobre un nopal devorando una serpiente". Siguiendo este designio, los mexicas deambularon por varios lugares, siempre en busca de la señal. De acuerdo con la Tira de la Peregrinación, la gente de Cuitláhuac se separó del resto de los calpullis. Más tarde, los mexicas llegaron al Valle de México y pasaron por varios pueblos, hasta que se asentaron en territorio de los tepanecas de Azcapotzalco, a quienes les sirvieron como guerreros mercenarios." Instituto Nacional de Antroplogía e Historia, Mito de la peregrinación. Disponible en: http://www.templomayor.inah.gob.mx/historia/mitode-la-peregrinacion. Para un examen mayor de este tema, véase: Castañeda de la Paz, María, "De Aztlan a Tenochtitlan: Historia de una peregrinación", Latin American Indian Literatures Journal, vol. 18, núm. 2, 2002, pp. 163-212.

${ }^{7}$ Velásquez García, Erik, "Los habitantes más antiguos del actual territorio mexicano", en Nueva Historia General de México, op. cit., p. 55. 
la hegemonía azteca terminó por afirmarse, más allá del territorio que circundaba a Tenochtitlan, hasta diversas zonas remotas, en todas las direcciones. De hecho, esta hegemonía fue relativamente breve: duró menos de dos siglos, aunque resplandecía cuando, inesperadamente, se produjo el "Descubrimiento de América" y se inició la sistemática ocupación progresiva de su territorio por los conquistadores, cuya idea no era otra que la de apoderarse de nuevos territorios, someter a los nativos y fundar una base colonial al ritmo posible dada la acción de las circunstancias.

Pocos observadores advirtieron entonces, explícitamente, que con la llegada de los españoles, un periodo entero de gobernabilidad se cerraba. Si acaso podemos establecer un paradigma que ilustre la conformación del Estado en las civilizaciones prehispánicas, debemos señalar, en primer término, que la gobernabilidad estaba asegurada sobre pueblos dominados o subordinados por la fuerza, por la capacidad de sometimiento de la formación dominante. Esta estaba determinada a su vez por un complejo de factores entre los que se pueden incluir condicionamientos culturales, la cohesión interna de las poblaciones, su capacidad de concertar alianzas y, en definitiva, de una manera decisiva, su propio poder militar en caso de enfrentamientos. La caída de Tenochtitlán no cierra solamente un ciclo de dominación azteca: marca brutalmente la línea que cierra el florecimiento de las culturas americanas, dramáticamente interrumpido por el establecimiento irresistible de una sociedad de dominación y mestizaje. Pocos hechos ilustran este punto más brutalmente como las estimaciones de diversos autores sobre la dinámica demográfica. La población del mundo prehispánico, establecen sus datos, habría sido de 15 millones de personas en 1519; y de apenas 3 millones en $1550 .^{8}$

El establecimiento de un régimen político español en México fue tarea difícil y tortuosa. Hernán Cortés emprendió la conquista de México enviado por el gobernador de Cuba, Diego Velázquez, en representación del Rey de España.

La marcha de Cortés prosperó rápidamente, con el acicate del acoso de Velázquez, dispuesto a removerlo de su representación. Desde el inicio de su viaje, Cortés envió a los Reyes Católicos informes y bienes obtenidos de su marcha.

De su primera guerra formal con los aztecas había salido derrotado. Pero sus dificultades fueron superadas gracias al apoyo de otros pueblos, resentidos con los tenochcas y al creciente interés de España por las nuevas tierras.

${ }^{8}$ Cfr. García Martínez, Bernardo, "Los años de la expansión", en Nueva Historia General de México, op. cit., pp. 253-256. 
En 1521, en todo caso, Cortés, el Gran Capitán, aparece como la cabeza de la ocupación Española. ${ }^{9}$

Como se habrá advertido, la composición pluriétnica del territorio mexicano, ha sido desde tiempo inmemorial una constante. Sin embargo, incluso los asentamientos humanos de población numerosa y localizada en territorios densamente poblados, dio vida al emplazamiento de templos, caminos y elementos de defensa. No obstante, la continuidad de flujos humanos y, según conjeturan diversos antropólogos, las sequías prolongadas y la falta de alimentos terminaban por obligar a la población a dispersarse y buscar nuevos emplazamientos, lo que implicaba abandonar construcciones extraordinarias muchas de las cuales aún subsisten. Desde luego, parece justificarse la razonable conjetura de que la intensidad y frecuencia de los flujos migratorios producían graves conflictos y amenazaban la subsistencia urbana. Por lo demás, San Lorenzo (1500-900 a.C.), La Venta (1200-400 a.C.), Teotihuacán (150-750 a.C.) y Cuicuilco (800

${ }^{9}$ El gobierno de la Nueva España estuvo a cargo de una multiplicidad de órganos y personajes, establecidos de conformidad con las exigencias progresivas de las circunstancias. Desde luego, en el momento de la conquista la más alta autoridad era, precisamente, Hernán Cortés. Una de las circunstancias más complicadas a las que se enfrentó el conquistador fue la "Noche Triste", que fue la noche del 30 de junio al 1 de julio de 1520, donde los españoles huyeron de Tenochtitlan. "Los españoles habían entrado en la capital del imperio el 8 de noviembre de 1519 [...] En ausencia de Hernán Cortés, que fue a combatir la expedición de [...] Pánfilo de Narváez, el capitán Pedro de Alvarado quedó con mando en plaza en la capital azteca. Este adelantado decidió lanzar un ataque preventivo a los ocupados para evitar sublevaciones. En este caso, a la vista de los resultados, no valió más prevenir que curar. [...] Era una fiesta religiosa para los aztecas, para la que el propio Alvarado había concedido permiso. [...] En un momento dado, Alvarado ordenó cerrar todas las salidas del patio sagrado, y la fiesta trocó en masacre. [...] Esta brutal matanza rompió el statu quo y fue un antecedente de la Noche Triste. [...] La muerte de Moctezuma dejó a los españoles en una situación insostenible, cercados por miles de guerreros mexicas sedientos de venganza, y sin apenas víveres en el palacio Axayácatl. Para mayor adversidad, los nativos habían desmontado los puentes de acceso a la isla. [...] A la señal de Cortés los fugitivos partieron bajo la consigna de silencio, cuidando el relincho de los caballos. El plan era construir un puente con vigas del palacio de Axayácatl, salir de la isla y marchar hacia Tacuba, para luego reagruparse con sus aliados en Tlaxcala. No obstante los esfuerzos de sigilo, fueron detectados y en seguida el lago de Texcoco se atiborró de canoas cargadas de feroces guerreros, que acudían a la llamada de los tambores. [...] En un momento dado, algunos capitanes sugirieron a Cortés, herido en una mano, retornar para amparar a los rezagados, y él contestó que los que habían salido era de milagro. No obstante, intentaron el regreso por la calzada, pero enseguida toparon con Pedro de Alvarado, herido, uno de los últimos en escapar del infierno azteca. En la laguna quedaron sepultados cientos de españoles y tlaxcaltecas, junto con decenas de caballos y yeguas y el noventa por ciento del tesoro de Axayácatl. Al oír el relato de Alvarado, Hernán Cortés no pudo contener las lágrimas." Finalmente, Tenochtitlan fue tomada por los españoles el 13 de agosto de 1521. Delgado-Iribarren, Francisco, "La Noche Triste: Hernán Cortés y sus hombres sucumben a la venganza azteca", ABC. 21 de diciembre de 2013. 
a.C.-250 d.C.); en fin, posteriormente, las poblaciones circundantes del Lago de Texcoco (39 pueblos) ${ }^{10}$ disfrutaron de un territorio privilegiado, no exento de ambiciones y amagos. Incluso, la llegada tardía y el asentamiento de los aztecas solo pudo realizarse aprovechando el abandono de terrenos siempre húmedos y frecuentemente inundados, que constituyeron la base de lo que sería la relativamente breve pero siempre determinante presencia de Tenochtitlan, de menos de dos siglos. Los acontecimientos que envolvieron la llegada y la conquista de los españoles ponen de relieve la diversidad de poblaciones inconformes con la presencia azteca dominante, pero resignadas por su relativamente limitada capacidad bélica. En efecto, la conquista de México fue resultado, también, de la acción determinante de diversas poblaciones prehispánicas, en particular, los tlaxcaltecas, que hicieron posible derrotar a los aztecas después de las lecciones ofrecidas por la "Noche Triste". En suma, a pesar de sus continuidades y persistencias, es difícil atribuirle a esta inmensa variedad de pueblos, e incluso lenguas y culturas, el atributo de la cohesiva gobernabilidad; en cambio, existen múltiples testimonios que dan cuenta de las rivalidades y enfrentamientos entre los pueblos prehispánicos y de la continuidad de los movimientos migratorios que sometían al territorio a un estado permanente de alarma y disposición a la defensa. De hecho, los aztecas fueron, en primera instancia, esclavizados, antes de convertirse en guerreros mercenarios, primero, y en fuerza dominante más tarde. En los hechos, con todo, después de la terrible derrota sufrida por Cortés, es inexplicable su victoria sobre los aztecas, sin el concurso determinante de diversos grupos indígenas, como lo hemos mencionado ya. Entre ellos sobresalieron los tlaxcaltecas, quienes posibilitaron al conquistador la recuperación del Valle de Anáhuac.

La experiencia prehispánica hace visible la frecuencia y la intensidad de los asentamientos de tribus y grupos diversos, como también ilustra la fragilidad de su permanencia, a la luz de los efectos devastadores de crisis naturales diversas y de golpes de poblaciones rivales. La gobernabilidad era eficaz y, a la postre, insuficiente.

${ }^{10}$ En el tiempo del establecimiento de Tenochtitlan, en el gran lago de Texcoco, se registra el asentamiento de 39 pueblos distintos. En este caso, la gobernabilidad tiene dos significaciones diferenciadas. Una se refiere al gobierno interno de cada una de estas poblaciones, con variantes orgánicas, culturales e incluso lingüísticas, por una parte; y por la otra de la conformación de la totalidad de dichas poblaciones unidas por el lago y por el evidente interés de la convivencia del todo y su defensa frente a extraños. En ese sentido, no parece posible establecer la ingobernabilidad del territorio en su conjunto; al contrario, se trató, claramente, de una región protegida, unida por el comercio y el intercambio cultura. Aunque, desde luego, no faltaron los enfrentamientos internos. 


\section{La gobernabilidad en la Nueva España}

Años después, establecida por decreto Real la figura del Virreinato, como entidad articuladora del territorio y los pueblos de la Nueva España, su conducción se encomendó en 1535 al primer Virrey, Don Antonio de Mendoza. ${ }^{11}$ La continuación del momento de los capitanes hubo de desplazarse tierra adentro. El régimen virreinal transcurrió en México a lo largo de poco menos de tres siglos. ${ }^{12}$ Las resistencias indígenas fueron aisladas, débiles, aunque también cruentas. Los pueblos de México quedaron atados a los intereses de España y sus luchas contra Inglaterra. En rigor, la Independencia de México no nació esencialmente, por ejemplo, de causas estrictamente internas; fue desencadenada por enfrentamientos específicos en España, internos y externos, cuando los grupos y los intereses peninsulares más fuertes de México tomaron nota en marzo de 1808 de la invasión francesa de "la Madre Patria", de la designación en junio de 1808 de José Bonaparte como rey de los españoles y sus dominios, como también la insurrección española frente a dicho sometimiento y sus secuelas. ${ }^{13}$

${ }^{11}$ Al estudiar la conducción de la Nueva España, a cargo de los Virreyes, se advierte que la constante fue la inestabilidad del cargo; es decir, los periodos de gobierno de los virreyes no fueron iguales: algunos gobernaron durante días y otros por varios lustros. Pongamos como ejemplo los siguientes datos para ilustrar lo anterior: Antonio de Mendoza (1535-1550) y Luis de Velasco (1550-1564), ambos designados por el rey Carlos V, gobernaron 15 y 14 años, respectivamente, mientras que Francisco Ceinos, a quien el rey Felipe II encomendó los territorios de la Nueva España, gobernó, casi dos años, entre 1564 y 1566. No es ocioso mencionar que la permanencia o remoción de los virreyes se debió, también, a los buenos oficios que demostraban al cumplir con su función o a las faltas que cometían en el ejercicio del poder público. A esto hay que agregar las intrigas palaciegas de la Real Audiencia, el Consejo de Indias y los cortesanos españoles, a menudo interesados en nombrar como Virrey a un allegado suyo en los territorios novohispanos. Por su parte, algunas personas fueron relevadas del encargo en la Nueva España para hacerse cargo de las tareas de gobierno en el virreinato de Perú, como fue el caso de Luis de Velasco (hijo), virrey entre 1590 y 1595, y Juan de Mendoza y Luna (1603-1607), o, bien, para asumir otras funciones en España, como ocurrió con Pedro Moya de Contreras, virrey entre 1584 y 1585 quien asumió la Presidencia del Consejo de Indias.

${ }^{12}$ Las autoridades en la Nueva España fueron: el Rey de España; el Supremo Consejo de Indias, que tenía funciones ejecutivas, legislativas y judiciales: nombraba obispos y funcionarios reales, dirigía la hacienda, preparaba cédulas y órdenes; en fin, era Tribunal supremo de primera y segunda instancia; la Real Audiencia; los Visitadores; el Virrey, y los Ayuntamientos. Cfr. Arregui Zamorano, Pilar, La Audiencia de México según los visitadores (siglos XVI y XVII), México, Instituto de Investigaciones Jurídicas, Universidad Nacional Autónoma de México, 1981.

${ }^{13}$ En los años de la ocupación francesa de España, se decidió convocar a las Cortes en Cádiz y los convocantes buscaron que las diversas partes de España y los dominios americanos estuvieran representados: municipios, juntas provinciales, la población peninsular, que quedaría representada con un diputado por cada 50 mil habitantes, y las provincias americanas. Cfr. Paoli Bolio, Francisco José, La Constitución de Cádiz en 
En España, el pueblo se levantó en armas. Una Junta Suprema fue incapaz de enfrentar la emergencia y nombró una Regencia que convocó a elecciones. En México, el Ayuntamiento "consideró que por ausencia del Rey, la soberanía se había revertido al reino, lo que hacía indispensable convocar a una junta de ayuntamientos para decidir su gobierno". ${ }^{14}$ Los oidores se opusieron, temiendo precisamente que se extendiera la idea de establecer la independencia del virreinato.

No estaban mal orientados. Los peligros nacían más como resultado de la crisis europea y de la extenuación del virreinato, que como expresión de las fuerzas aportadas por los partidarios prematuros de la independencia. En 1808 Gabriel de Yermo encabezó una toma del palacio y el arresto del Virrey y del ayuntamiento. Sin embargo, las cosas se complicaron. Las conspiraciones se multiplicaron. El corregidor de Querétaro y su esposa, quienes reunían con frecuencia a capitanes, clérigos (incluido Hidalgo) y comerciantes, tramaron una insurrección. Pero los aires ya habían cambiado: los participantes fueron denunciados y buscados. Hidalgo se sintió arrinconado y obligado a convocar a sus feligreses a luchar "contra el mal gobierno". De manera inesperada se iniciaron los movimientos insurgentes que, de inmediato, se extendieron a diversas ciudades coloniales. Desde luego la reacción de los peninsulares no se hizo esperar: prácticamente todos cerraron filas y el virreinato inició la lucha contra el levantamiento. Apenas menos de cuatro meses después, el ejército realista había derrotado a las fuerzas insurgentes. Los triunfos virreinales se

Iberoamérica, México, Instituto de Investigaciones Jurídicas, Universidad Nacional Autónoma de México, 2016. Fueron 21 los diputados enviados desde lo que ahora es México que participaron en las Cortes de Cádiz: 15 propietarios y 6 suplentes. "Entre los diputados acreditados, catorce eran eclesiásticos, y de entre ellos cinco hicieron la carrera de leyes; dos militares; otros dos eran comerciantes; dos más eran funcionarios, y uno era abogado." Los diputados fueron: Beye Cisneros Prado, José Ignacio; Cárdenas y Romero, José Eduardo; Cuoto e Ibea, José María; Fernández Munilla, Francisco; Foncerrada y Ulibarri, José Cayetano; González Lastri, Miguel Mariano; Gordoa y Barrios, José Miguel; Guereña y Garayo, Juan José Ignacio; Guridi y Alcocer, José Miguel; Gutiérrez Terán, José María; Maldonado López, José Máximo; Maniau Torquemada, Joaquín; Mendiola, Mariano; Moreno, Manuel María; Obregón y Gómez, Octaviano; Pérez Martínez, Antonio Joaquín; Pino, Pedro Bautista; Ramos Arizpe, José Miguel; San Martín y Cuevas, Salvador; Savariego y Colonia, Andrés, y Uría y Berrueco, José Simeón de. Cfr. Barragán, José, "Los diputados novohispanos en las Cortés de Cádiz”, en Barceló Rojas, Daniel y Serna de la Garza, José Ma. (coords.), Memoria del Seminario Internacional: Conmemoración del Bicentenario de la Constitución de Cádiz. Las ideas constitucionales de América Latina, México, Instituto de Investigaciones Jurídicas, Universidad Nacional Autónoma de México-Senado de la República, 2013, pp. 66-77.

${ }^{14}$ Zoraida Vázquez, Josefina, "De la Independencia a la Consolidación Republicana", en Nueva Historia Mínima de México, México, El Colegio de México, 2004, p. 140. 
repitieron y, poco tiempo después, el orden estaba restablecido, aunque no sin sobresaltos y temores. Sin embargo, la lucha continuó: un nuevo protagonista. El ciudadano mexicano había nacido y se había extendido en diversas direcciones, dirigido esta vez por individuos de la talla de Morelos y Rayón. El movimiento insurgente ganó estructura, disciplina y cohesión, y obtuvo razonados éxitos aunque, finalmente, fue vencido. Morelos fue apresado y ejecutado en diciembre de 1815. El golpe fue terrible. Sin embargo, en España, después de diversos episodios que mantuvieron ahí viva la guerra civil, se produjo un giro democrático y liberal con la instauración de la Constitución de Cádiz de 1812. Una vez más la coyuntura española reanimó el conflicto. El rey fue forzado a jurar la Constitución y el imperio fue convocado a nuevas elecciones. En la Nueva España, el ejército y la iglesia, alarmados por los acontecimientos, apoyados por los peninsulares se inclinaron por la independencia. El Virrey, por su parte, confió el Mando del Sur a Iturbide quien, en ese cuadro, lejos de perseguir a Guerrero y a Bravo, les ofreció un acuerdo de unidad, encabezó la lucha. Todo había cambiado. Finalmente, después de diversas peripecias, el 27 de septiembre de 1821 la Ciudad de México acogía al "Ejército Trigarante" y daba paso a la fundación de un Estado independiente.

Conviene destacar dos puntos: 1. Aunque los levantamientos independentistas no habían triunfado, la derrota era cuestión de tiempo. A lo largo de poco más de 10 años de lucha, se había hecho evidente el agotamiento de la capacidad del imperio español de mantener el dominio sobre sus colonias. Ahora bien, en segundo término, el lapso mismo, prolongado, de luchas y enfrentamientos habían puesto en claro, fortalecido y finalmente consolidado un Estado de facto, sin acuerdos internos. Aunque la lucha de independencia terminó con un acuerdo general, debido en gran medida al agotamiento de la metrópoli, las fuerzas de la independencia; esto es, los grupos de criollos favorecidos por la agotada colonia, se enfrentaron entre sí casi inmediatamente. La discusión y aprobación de la primera constitución mexicana, la de 1824, hizo evidente la profundidad de los desacuerdos y las contradicciones en juego, como también la imposibilidad de superarlos entre los partidarios triunfadores de la independencia.

Guadalupe Victoria tomó posesión y cumplió un periodo completo de cuatro años, en octubre de 1824. En 1828 se llevaron a cabo las elecciones para la primera sucesión presidencial. La elección produjo un enfrentamiento entre los aspirantes y diversos motines y levantamientos. Vicente Guerrero y Gómez Pedraza se enfrentaron en aquel tiempo, mientras Bocanegra asumió 
la Presidencia interina. La gobernabilidad pacífica había durado apenas un periodo. Por las más diversas circunstancias, habrían de pasar poco más de cinco décadas antes de que se normalizara la transición en la titularidad de la Presidencia de la República. La sucesión de gobernantes fallidos fue sobrecogedora y ofreció el contexto en que se libraría la guerra de Estados Unidos y la grotesca ocupación francesa después. En ese cuadro, Benito Juárez ocupó la Presidencia repetidas veces, hasta que, en 1872, la muerte interrumpió su último periodo; sin embargo, conviene recordar que, a lo largo de ese dilatado periodo, Juárez había enfrentado diversos golpes. En 1859 ocupó la Presidencia de México Miguel Miramón, quien en 1860 ocupó la "regencia", hasta la llegada de Maximiliano en 1864. El encargo del emperador duró poco más de tres años. Con su muerte no fue sustituido: el imperio desapareció. Entre tanto, Juárez había ejercido una itinerancia. En fin, como hemos mencionado, pudo mantener la Presidencia hasta 1872. En ese contexto se produce un giro sorprendente en nuestra historia política. En efecto, a pesar de los múltiples incidentes, Miguel Lerdo de Tejada asumió la Presidencia en 1872 y terminó su periodo, Iglesias careció de la enjundia para constituirse en el continuador y cerca de dos meses después, surgió Porfirio Díaz, "Don Porfirio" quien, con un breve paréntesis de cuatro años, habría de controlar el poder desde 1877 y gobernar sin interrupción hasta 1910, cuando vencido por los años y acosado por Madero, se retiró al exilio parisino. ${ }^{15}$

${ }^{15}$ La incapacidad para articular un proyecto nacional compartido fue evidente durante las primeras décadas del México independiente. Guadalupe Victoria fue, entre octubre de 1824 y marzo 1829, el primer presidente de México y el único gobernante que pudo terminar en un largo lapso su periodo presidencial. Después, la constante fue el cambio continuo de presidentes: Vicente Guerrero gobernó unos meses en 1829. Lo mismo sucedió con José María Bocanegra. Anastasio Bustamante inició su gobierno en 1830 y lo finaliza en 1832; lo mismo le ocurrió a Melchor Múzquiz quien, a su vez, fue relevado por Manuel Gómez Pedraza, el mismo 1832. Después, asumió la Presidencia de México, Valentín Gómez Farías, cuando apareció, por primera vez, Antonio López de Santa Anna, quien ocuparía 11 once veces el poder Ejecutivo. Podemos registrar los nombres de José Joaquín Herrera, Mariano Paredes y Arrillaga, José Mariano Salas, Pedro María Anaya, Manuel de la Peña y Peña; en fin, Juan Bautista Ceballos, quienes fueron sucesores efímeros de Santa Anna, y cuyos gobiernos no llegaron a un año. No es sino hasta el primer periodo de gobierno de Porfirio Díaz, cuando los presidentes de México pueden culminar su (entonces) cuatrienio. Aún en los días de la intervención francesa, y a pesar de la continuidad del gobierno itinerante de Benito Juárez, las circunstancias del momento y la existencia de dos gobiernos: uno republicano, y otro monárquico, la ausencia de gobernabilidad fue la marca distintiva. Esta situación se modificó, como hemos dicho, con la presidencia de Díaz quien obtuvo la última de sus reelecciones el 10 de julio de 1910 y renunció en mayo de 1911. La Revolución Mexicana restableció la inestabilidad: el asesinato de Madero, el levantamiento contra Huerta, la Convención Revolucionaria que nombró a sucesivos gobernantes de México: Roque González Garza, Eulalio Gutiérrez y Francisco S. Carvajal; en fin, el triunfo del constitucionalismo, con 
La inestabilidad, interna y externa, y la incapacidad de prever y contener la ingobernabilidad, destacan a lo largo de las décadas de reformismo fragmentario, renuente a admitir una fórmula democrática como fuente única del poder: ¿Quién anticipó que el gran ciclo de reformas post-68, no solamente iniciaría el proceso de acotamiento del predominio presidencial; si no que desencadenaría también un periodo de fragmentación que terminaría por requerir la formación de mayorías pluripartidistas, de pluralidad en los gobiernos locales y, simultáneamente, por afianzar el sistema de partidos, a más de un siglo de distancia; esto es, terminaría por desvanecer el propio resorte postulado como la matriz esencial del proceso? ¿Quién previó que después del ya remoto "milagro mexicano" la economía nacional sería absorbida por la "globalización" y tropezarían, sin remedio, las perspectivas del Estado social, de derecho y democrático, postulado por la Constitución y, consecuentemente, que se prolongarían los obstáculos que impiden la plena encarnación de un Estado de bienestar para todos; en fin, se consolidarían y extenderían inevitablemente, en cambio, las inconformidades políticas.

En suma, después de un largo proceso legislativo de "reforma política" y cambio, y de creación consecuente de un sistema plural de partidos, sin un integrante hegemónico, sobrevive la sociedad dual: el México del sector moderno, globalizado, dinámico con sus fuerzas y debilidades, ahora adherido al Mercado Común de América del Norte, separado de los ya distantes Estados Centro y Latinoamericanos; convertido en fin en un Estado acorralado, de población pobre, migrante, informal, en movilidad y sin asideros.

Para explorar las distintas dimensiones contemporáneas de la gobernabilidad en el Sistema Político Mexicano, a la luz de la variedad de factores histórico-

Venustiano Carranza como Primer Jefe, y el Congreso Constituyente que promulgó la Carta Magna de 1917, fueron acontecimientos que se alargaron un quinquenio. Insistamos en el punto: Los primeros datos son asombrosos: recordemos que Iturbide se hace cargo del poder en 1821, y refrenda su mandato por distintas fuentes dos veces, en 1822. Concluye en definitiva en 1823. Lo sustituye Miguel Domínguez, quien gobierna por un breve plazo, aunque vuelve a hacerlo 4 veces más, con nombramientos sin futuro, entre 1823 y 1824. En 1823 son 9 los mandatarios que se hacen cargo fugazmente de la Presidencia y el cargo 13 veces en 1824, hasta que Guadalupe Victoria es electo Presidente, gobierna exitosamente y concluye su encargo en 1829. Son entonces 5 presidentes fugaces, quienes ocupan el cargo a lo largo de ese año. Las alternancias que se registran entre 1830 y 1835 son 12; y son 30 las que se producen entre esa fecha y 1853; en fin, son 26 los movimientos de Presidente los que se producen de dichos años, hasta 1876, cuando Porfirio Díaz, se hace por breve lapso de su primera Presidencia. Como es obvio, todas estas décadas expresan elocuentemente la ingobernabilidad a la que se enfrentó la sociedad mexicana a partir de la conquista de la independencia cuando se multiplican los aspirantes que con apremio desean cargo de la Presidencia. La ingobernabilidad es patente. 
sociales que las determinan, será necesario emprender un largo recorrido. Adelanto que enfrentamos un tema inmerso además en la ideología; esto es, en las razones doctrinarias y los intereses que inspiran la expresión de los protagonistas de la vida política, recurriendo a planteamientos acaso dogmáticos y ciertamente sesgados, aunque, en todo caso, consecuencia de realidades duras (ancestrales y nuevas); como enfrentamos también tareas cruciales y precisas, por diversos grupos, asumidas desde sus propias perspectivas, impulsados por intereses insatisfechos y la percepción expresada de lo que cada uno juzga merecer, en contraste con lo que recibe. Esto es así porque el fondo de esta cuestión, convoca, inevitablemente, a una variada constelación de intereses diferenciados, acaso sobrepuestos, aunque también nos conduce a lo más profundo de la historia, en particular a su origen; como también nos remite a los valores que la expresan. Se trata, para los protagonistas, de asumir, o rechazar como eje central de la convivencia, un esquema determinado de distribución de recursos, tareas y oportunidades; esquema que postula y expresa, en la práctica, el balance real del poder, al margen de los postulados formales y de las diversas representaciones que dichos protagonistas construyen sobre sus merecimientos, en contraste con lo que reciben; esto es, se trata de la repartición social de cargas y beneficios entre fuerzas, estamentos, sectores, clases e individuos; de la repartición que sería "justa", "aceptable"; y de la que no lo sería. Toda comunidad política enfrenta la cuestión decisiva de construir los factores determinantes de su funcionamiento; es decir, la cuestión de la gobernabilidad; lo que significa para cada integrante, jugar o no hacerlo, en los términos establecidos.

En cualquier circunstancia, la cuestión vital es la adhesión al sistema. Su comprensión reclama hoy una atención inaplazable, máxime a la luz de los diversos signos que son señales inconfundibles de tendencias propias, si no de un Estado fallido, al menos de un Estado pasmado.

Comenzaré abordando dos cuestiones cuyo tratamiento me parece ineludible: en primer lugar, para empezar, ¿cuál es el concepto, la naturaleza, del Estado fallido? ¿Es una herramienta de análisis; esto es, una categoría descriptiva de los atributos de una nación en crisis de gobernabilidad?; y, enseguida, ¿ofrece dicha herramienta un "modelo conceptual" idóneo para describir hoy la coyuntura mexicana?

Precisemos el enfoque que se propone: para analizar la cuestión de la gobernabilidad en México, requerimos contar con instrumentos adecuados para identificar y captar los componentes propios de un Estado de Derecho, "gober- 
nable"; para contrastarlos con aquellos correspondientes a un Estado arbitrario, inviable, "fallido". El objetivo consiste, enseguida, en registrar los hechos que nos permitirían establecer si están suficientemente presentes los atributos propios del Estado fallido. Responder a estas cuestiones será clave para describir y diagnosticar las perspectivas de la gobernabilidad en México. Después de todo, para avanzar en nuestra ruta, no es clave dictaminar si en el pasado remoto el Estado carecía de prerrequisitos para calificarlo de "viable" o "no viable". La clave está en la descripción de los atributos propios del Estado mexicano contemporáneo, in situ, hoy. ¿De qué manera se produjo el pasaje de una dictadura, encabezada por un militar renombrado y temido, capaz de mantener a lo largo de 30 años la conducción del poder político, a un régimen ocupado en la construcción de acuerdos entre los distintos componentes de las fuerzas y élites mexicanas?

Volvamos al siglo XIX. Es difícil no reconocer que un país convulsionado por más de una década de guerra civil, desde 1810 hasta 1824, para pasar, a continuación, a la fundación de un Estado nacional perturbado por el desacuerdo, la inestabilidad, la ausencia de instituciones, la pobreza, la invasión y la rapiña norteamericana reiterada; la querella conservadores-liberales; la intervención francesa y la persistente voracidad norteamericana expresada por los intereses mineros y petroleros; haya terminado en la conformación de una República gobernable, así haya sido de manera simultánea una dictadura y un Estado liberal; capaz de resistir sus propias contradicciones internas y la voracidad norteamericana. Es un enigma. Sin embargo, así fue: el porfiriato condujo a México a lo largo de un difícil camino al inicio del siglo xx conformado ya como Estado nacional. Es igualmente preciso subrayar que el porfiriato desembocó, a la postre, nuevamente, en un país ingobernable, cuando el establecimiento del nuevo régimen, ganado con el triunfo de la revolución maderista, desembocó en la guerra civil de los revolucionarios contra el ejército federal huertista hasta 1915 y posteriormente en una guerra interna por el poder de la que emergería como triunfador Carranza, dada la capacidad de sus fuerzas y el apoyo de Obregón, Calles, González, entre otros; y muy particularmente su sagaz decisión de modificar las bases sociales vigentes en México mediante la reforma agraria, los derechos obreros, el establecimiento de los salarios mínimos; en fin, la gradual institucionalización del ejército. Sin embargo, habían de ser necesarios los años de luchas intra-revolucionarias que enfrentaron a Carranza, renuente a dejar el poder, contra los generales norteños, en particular los sonorenses, quienes deseaban acceso a la Presidencia. 
Con la caída del Primer Jefe, Adolfo de la Huerta gobernó transitoriamente unos cuantos días y Álvaro Obregón estableció un gobierno de reconstrucción militar, reorganización civil, educación pública y regularización de los conflictos internacionales, en especial con Estados Unidos. Calles añadió más tarde, a esta agenda el fortalecimiento de las organizaciones populares y el constreñimiento a los excesos del clero católico. Finalmente, pese a las enseñanzas de la propia Revolución, Obregón cedió a la tentación de volver al cáncer reeleccionista. Fue asesinado. Calles decidió asumir el papel de "Jefe Máximo" y transferir cuatrianualmente el poder. Pocos años después, en 1936, Lázaro Cárdenas lo envía a Estados Unidos y cerró por siempre el Maximato. Todas las sucesiones a partir de ese momento han sido regulares. El periodo presidencial se hizo de seis años y todos los presidentes sin excepción, entregaron puntualmente el cargo. Todos ellos eran miembros de la élite política de los revolucionarios, primero, y de sucesores, después, hasta el año 2000, cuando se produce una alternancia electoral y pacífica de la Presidencia.

\section{Propuestas y proyectos}

Resumamos: en México, ya sabemos, en los primeros años del siglo pasado, con motivo de la sucesión presidencial de 1910, se inició un periodo confuso de proclamas y movimientos sociales sobrepuestos, que precedió al inicio de lo que sería, a la postre, la Revolución Mexicana, cuyo momento estelar se puede ubicar, simbólicamente, en el texto de la Constitución Política de 1917, que es más un proyecto de Nación que la expresión normativa constitucional. Igual ocurre con el largo proceso de su gradual implantación, sin que ello signifique que no existan normas acaso incongruentes entre sí o bien postulados y objetivos inalcanzables en el cuadro de desigualdad extrema, postración social y lucha civil. En efecto, el texto consagró el pacto concertado entre las heterogéneas fuerzas que derrocaron al antiguo régimen, en agosto de 1914, así se hayan enfrentado por el poder las fuerzas vencedoras.

El texto de la Constitución es el resultado de un debate que inicia con la sorpresiva asistencia inaugural del Primer Jefe del Ejército Constitucionalista, encargado del Poder Ejecutivo de la Unión, Venustiano Carranza, quien comunicó a los diputados que "tendría la satisfacción de concurrir a los debates cuando (se discutiera...) el artículo tercero del referido proyecto". No obstante, la moderada postura de Carranza iba en contra del sentimiento general de los 
miembros de la comisión y del Congreso Constituyente. El resultado fue la consagración del principio de que "La enseñanza es libre, pero será laica (la que se dé en los establecimientos oficiales de educación) (...) igual que la enseñanza primaria, elemental y superior que se imparta en los establecimientos particulares".

A falta de un proyecto aglutinador compartido por los vencedores, el documento integró, más simbólica que categóricamente, el reconocimiento formal a los intereses y proyectos de las fuerzas triunfadoras, unidas frente al porfiriato, aunque después enfrentadas entre sí; e hizo suyo el listado de proyectos de los diversos bandos para aglutinarlos.

Consecuentemente, la Constitución asignó potestades y beneficios políticos a diversos estratos sociales, al implantar reformas acordes con la demandas e intereses de diversas fuerzas; por ejemplo, la retoma del federalismo en favor de estados, municipios, e intereses regionales y nacionales, enfrentados al centralismo prevaleciente; las reformas agraria y laboral, en favor de grupos rurales, la primera; y urbanos, la segunda; en fin, el reconocimiento a clases sociales (en incubación, las profesiones; ascenso, proletario, o agotamiento) y el reconocimiento a bloques sectoriales, portadores de aspiraciones o demandas acaso enfrentadas entre sí, apoyadas por fuerzas diversas que, sin embargo, debían ser integradas. El pacto que expresó y concretó los acuerdos consecuentes, fue la Constitución de 1917, caracterizada por una armazón múltiple y polivalente, ya que fue concertada y establecida en la perspectiva del acuerdo de construir una sociedad que volviera a sus raíces primigenias y, simultáneamente, pasara del siglo XIX al XX, reconciliada consigo misma.

La tarea era colosal: había que restablecer la paz y proponer y encarnar un proyecto de nación reunificador de los bandos (vencedores y vencidos). El hilo que condujo su redacción repitió la ilusión del régimen político imaginado en la Constitución de 1824, promulgada de cara a una sociedad rural y mal integrada, fragmentada y lastimada por las desigualdades étnicas y sociales, sacudida por la demanda de cambio y alebrestada por las inevitables discrepancias, resistencias y discordias; resuelta a conservar su integridad, aunque sin los resortes para protegerse, e incapaz de proponer el guión de un orden reconciliador posible, consentido, en el que todos cupieran. Como resultado, el constituyente de 1917 consagró todo: desde el sueño regresivo a la vida comunitaria, campesina, hasta las aspiraciones utópicas de construcción de un futuro moderno, dinámico, igualitario y reconciliador. Intentó así integrar el ejido y la agricultura comercial y de exportación; las artesanías con la industria y la expansión de 
los servicios, entre ellos las profesiones; impulsar la participación generalizada, y también selectiva, la igualdad y las diferencias; en fin, el nacionalismo y el influjo extranjero... Por lo mismo, el Constituyente de 1917 imaginó el primer despertar de la revolución laboral, consecuencia necesaria de la expansión industrial, la urbanización y el desarrollo económico; soñó con apuntalar las aspiraciones locales y nacionales (y hacerlo, además, al margen de los poderes privados); se pensó, como el consolidador de la base de la nueva sociedad, en un orden secular y extenso que fracturaría al poder clerical, e integraría una sociedad en la que todos cabrían.

Ese fue el proyecto. En contraste, la sociedad de 1917 era desigual, heterogénea, contradictoria y dinámica; una sociedad comunitaria, campesina, artesanal y desintegrada en regiones, etnias, y distintos conflictos; y también una sociedad de servicios, sectores urbanos, comunidades aisladas y en desvanecimiento étnico en la urbe; grupos alucinados por la inminente modernidad o integrados ya por la inasible globalidad; grupos colocados al lado de sectores urbanos ya establecidos, con aspiraciones infinitas; de fuerzas enredadas en luchas rurales y religiosas; de sectores privados y extranjeros de todo tipo; sociedad cuyos primeros intentos de reconstrucción e intercambio armónicos y bienhechores entre regiones y sectores, reconciliados por la industrialización y el comercio, ya se habían desvanecido para finales de los años cincuenta con las revueltas internas sofocadas, la desigualdad, la pobreza, guerra, la crisis mundial y las insuficiencias. Apenas cuatro décadas después de promulgar su Constitución agraria, instrumento de integración masivamente rural, México era ya un país primordialmente urbano, aunque, para colmo, no había resuelto muchas de sus querellas campesinas. Un país que, agreguémoslo, había alcanzado un nuevo equilibrio social con la expansión de los servicios y las manufacturas, y cuya población se instruía y redistribuía acelerada y desigualmente: la población urbana ganaba espacios y expansiones en detrimento del mundo rural, ${ }^{16}$ mientras la educación, los servicios de salud, la administración pública, las profesiones y el empleo femenino se expandían, así fuese desigualmente. Desde luego, el texto de la nueva Constitución no podía incluir la visión de una sociedad terciaria, menos aún un esquema de la forma de organizarla; como tampoco la apertura sistemática al exterior, el vuelco al pluralismo en el orden étnico, cultural y religioso; o bien, la apertura a la emergencia de una sociedad "abierta"; dispuesta aunque con reticencias, a incluir a los géneros, los diversos grupos de edad, las

${ }^{16}$ La población urbana se registra como preponderante solo a partir del Censo de 1960. 
diferentes creencias, inclinaciones y gustos, como también, decidida, a la postre, así fuera formalmente, a respetar y proteger las diferencias y las discrepancias.

La sociedad rural contemporánea es dispersa, fragmentada, aunque diferenciada y con un sentido de solidaridad comunitaria intenso; sentido arraigado y fundado en relaciones culturales y familiares locales. La visión de dicha sociedad es estrecha y distante de la perspectiva variada, heterogénea y discrepante de la Nación urbana; sin embargo, está igualmente expuesta y conducida a la televisión, el radio, el asalto de grupos externos, los empellones de la administración; la escasez, el crimen, el mundo global, la demografía y los mercados; en fin, dicha sociedad experimenta hoy los desafíos de su propia maduración y aquellos consecuencia de sus emigrados, transterrados, excluidos, desaparecidos o reincorporados. El proceso de impulsarla a salir masivamente de sus certidumbres geográficas y culturales, no ha sido ajeno al debilitamiento de la solidaridad y la experiencia de la violencia. Peor aún, las insuficiencias productivas condujeron a romper y abandonar los compromisos de modernizar el campo, de abrir perspectivas mediante políticas de "modernización" y "movilidad": el abandono de los compromisos con la producción agropecuaria generó fracturas y rompimientos que todos, a veces, lamentamos en vano.

Ordenemos la visión del pasado: vale la pena resaltar el tempo y los modos del proceso de expresión de la Revolución Mexicana: esto es, la revolución social, extendida, profunda, sangrienta y decidida condujo al México de medio siglo. Volvamos a decirlo, la Revolución se inició contra Díaz, con motivo de las sucesión presidencial de 1910, el anunciado retiro fallido de Díaz y la querella electoral maderista, estallada en noviembre de ese año; movimiento que se profundizó y que extendió sus demandas a lo largo del gobierno de Madero (asesinado en febrero de 1913), y alcanzó su máxima expresión en la lucha contra Victoriano Huerta, finalmente derrotado (agosto de 1914); apenas para reanudarlo de inmediato, con nuevos bríos y extensión, como lucha entre facciones, no sin antes intentar enfrentar los dilemas de su propia diversidad con la tentativa de unidad y reconciliación, objetivos de la Convención de Aguascalientes, fracasada en octubre del mismo año.

Así, se planteó en los hechos el dilema de determinar qué fuerzas gobernarían a México y cómo habrían de hacerlo; peor aún, con la derrota de Huerta, la multiplicación de las facciones revolucionarias, la emergencia de fuerzas armadas regionales y el surgimiento de movimientos y organizaciones sociales se modificó en el cuadro de la lucha y la concertación de alianzas, la dinámica misma de la Revolución. 
En esas condiciones, para entonces la tarea era ya totalmente distinta a la de establecer quién gobernaría. Con la refundación política y social de la Nación, iniciada formalmente con la Constitución de 1917, y bajo la conducción de "gobiernos democráticos", al lado de una nueva alianza política y social; como también la refundación del Estado, constitucionalmente responsable de emprender las reformas y la modernización del país y sus leyes; la adopción finalmente eficaz de la no reelección y la emergencia de los partidos; la persistente resistencia a la intervención del ejército, que impulsó su profesionalización, con la promulgación de la Constitución; en fin, abierta la inclusión social progresiva, en el cuadro del texto de 1917 se conformaron, ampliaron, decantaron, y construyeron los lineamientos de la agenda nacional acordada, reformada y aplicada a lo largo de todo el siglo Xx, para alcanzar una República aunque ciertamente desigual, insuficiente y corrompida, capaz de acoger y reconciliar ideológicamente a todos. Como sabemos, dichos lineamientos acordados siguen logrando su sentido en las primeras décadas del siglo XXI.

Volvamos al tema central: saber quién va a gobernar dejó de ser el núcleo de interés. En cambio, la cuestión de cómo hacerlo, sustantiva y procedimentalmente, con qué límites, objetivos y potestades, con qué proyecto, ritmo y costo, cobró el rango de cuestión central. Hemos recordado que con la derrota de Victoriano Huerta, el problema de la sucesión presidencialmente inevitable despertó de nuevo la lucha por el poder; ésta vez entre los partidarios de Villa, Zapata, Carranza, González, y otros revolucionarios. Con dicha derrota, las facciones revolucionarias perdieron al enemigo común y la Convención de Aguascalientes hubo de intentar, en vano, reconciliar a todas las facciones y construir un acuerdo. No lo logró; al contrario, la diversidad de aspirantes se convirtió en fuente inevitable del conflicto. El Presidente de la Convención, Eulalio Gutiérrez, entendió que contaba con un mandato superior de gobierno. Pero algo similar entendieron el Primer Jefe, Carranza; Villa y, tal vez, Zapata. Así, a finales de 1914, estalló la verdadera revolución masiva y brutal, breve aunque decisiva. A falta de acuerdos, la querella quedó resuelta por la fuerza, en lo fundamental, a mediados de 1915, con la derrota de Villa y el regreso de Zapata a Morelos. En esa coyuntura, se superó gradualmente la fragmentación de fuerzas regionales diversas. Articularlas progresivamente en una corriente nacional hegemónica conducida por el Primer Jefe fue la propuesta del grupo triunfador de Carranza, y fue el fruto de convocar al Congreso Constituyente, construir un acuerdo nacional y contar con una nueva Constitución, enriquecida por diversas propuestas nacionales y sociales. 
¿Por qué el proceso se resolvió así? Es difícil precisarlo. Lo cierto es que la revolución confrontó a dos grandes alianzas revolucionarias: una, la villista, de norteños de origen diverso; aliada a la zapatista, del sur, de la periferia de la Ciudad de México, fundamentalmente campesina, comunitaria, precapitalista; la otra, encabezada por Carranza, moderna, constitucionalista, obregonista; con fuerzas del Pacífico y el norte de la República: territorios de la agricultura moderna; de ciudades, profesiones, y sectores obreros y urbanos... Cuando estalló la querella interna sangrienta, a finales de 1914, los carrancistas contaban apenas con el control de Veracruz y de algunas zonas y posiciones aisladas en el norte, y con el apoyo de Pablo González. Sin embargo, contaban con un proyecto moderno integrado; con organizaciones urbanas y obreras, administradores, con una línea "nacionalista", con la propuesta de los salarios mínimos y de medios del trabajo; en fin, con la reforma agraria. En los primeros meses del año siguiente habían ganado el control de todo el país. Esto lo hicieron gracias al conocimiento; a las ventajas de su formación; a la participación urbana: opuesta a la nota de sus rivales: campesinos, vaqueros poco instruidos y sin proyecto del futuro. Obregón era asombroso: contó con la información y comprensión de las tácticas probadas en la Primera Guerra Mundial, y se impuso la tarea del aprendizaje de las estrategias triunfadoras: militares primero, y subalternos, después, como consecuencia, el resultado fue la hegemonía política, base de la construcción de un proyecto de país moderno, abierto a la globalización de entonces; tarea que propuso la aspiración, así fuera remota, de construir una República democrática productiva.

En la batalla de Celaya, triunfaron las tácticas de contención con trincheras propias de la guerra de Europa. Obregón sabía lo que ocurría en Francia y Alemania. Desde el primer enfrentamiento, Villa estaba derrotado; sus infructuosas cargas de caballería y embates frontales; su gran ímpetu de guerrero fueron inútiles: no pudo hacer nada con su ataque abierto, frente a un terreno de canales, alambradas, trincheras y ametralladoras que lo esperaban. El triunfador, fue el movimiento constitucionalista; esto es, quien estableció y proclamó, antes, la reforma agraria, primero, concebida y publicitada desde el refugio de Veracruz, donde fue convertida en la Ley del 6 de enero de 1915; cuyo texto le granjeó el apoyo campesino, y se incorporó en el Constituyente como el núcleo fundamental al artículo 27 constitucional. Agreguemos que fue Carranza quien reestableció el principio de laicidad, quien consagró, con otra reforma constitucional, el divorcio; quien impulsó el acuerdo con la clase obrera y su Revolución, y quien se concentró en superar la intervención de Estados Unidos, apoyado por Cabrera; y en diseñar un Estado constitucional de 
ciudadanos iguales, así fueran en la práctica desiguales, dotados de derechos y garantías individuales. Se había construido una nueva gobernabilidad.

Ahora bien, las décadas se agolparon. La nueva concepción de Carranza y el haz de políticas públicas estaban ya agotadas en los años cincuenta: la sociedad mexicana había cambiado. El crecimiento urbano fue decisivo. El país se había convertido en buena medida en una sociedad de clase media urbana: contaba ya con un influyente elemento profesional, y enfrentaba problemas nuevos: la urbanización, la industria, los servicios, la agricultura moderna, el mercado externo, la expansión de los servicios educativos, simbolizada por la construcción, en la capital de la República, de Ciudad Universitaria, formalmente terminada en 1952, año de conclusión del periodo de Miguel Alemán, aunque realmente consumada en 1954.

Los años previos al medio siglo, registran la creación del Instituto Politécnico Nacional (1936-1937) y la expansión de las normales nacionales, acogieron e impulsaron el primer gran jalón a la investigación científica en México, registraron la diversificación y ampliación de las ocupaciones y el empleo, merced a los mercados financieros, bancarios, de aseguramientos, y la expansión del comercio como fuentes decisivas para la expansión del Producto Interno Bruto (PIB). En ese cuadro, la Constitución fue reformada una y otra vez aunque, al margen de las intenciones, no para acoger una nueva realidad y admitir el pluralismo sino, en los hechos, para convertir a México en un Estado articulado, centralizado, presidencialista, capitalista protegido por la capacidad de movilización de sus recursos y la generación de una burocracia eficaz. Sin embargo, dos décadas después, con los sexenios iniciados en 1958, 1964, 1970 y 1976, esta sociedad había cambiado aún más y el Estado había expandido su acción, la sociedad se había diferenciado y su equipamiento institucional se había rezagado y quedado atrás. La demanda de renovación institucional era inevitable: el dinamismo del desarrollo y la demanda externa generada por la Segunda Guerra y la guerra de Corea habían contribuido a generar un mercado del trabajo dinámico y diferenciado, que ofrecía una base amplia a la protesta social; en el sector privado, desde luego, pero crecientemente también en el sector urbano, público y profesional; sectores a los que se agregaba la agricultura diversificada por la introducción de productos de alto rendimiento y moderado empleo, como la caña, el algodón, las hortalizas, que sustentaron también aspiraciones y protestas masivas. En los servicios se registró un cambio espectacular: electricistas, ferrocarrileros, petroleros, maestros, profesionales, administradores y burócratas se sucedieron reclamando atención, 
derechos, mejores ingresos, libertad y autonomía de organización y asociación a lo largo de los años de la década de los cincuenta y buena parte de los sesenta. Casi simultáneamente, la revolución cubana, los conflictos regionales en Centroamérica y el Caribe, y las incidencias de la coyuntura en Colombia, Perú, Venezuela, Brasil y Argentina; en fin, el inicio del gobierno de Kennedy y sus injerencias expansivas, replantearon, en los hechos, la agenda en México y pusieron a prueba las inconmovibles estructuras piramidales del poder, en contraste con la diversidad de proyectos, propuestas y demandas que animaban los sectores urbanos, el mundo de las profesiones, en particular los médicos; los conflictos producidos por la oposición laicista al intervencionismo clerical azuzado y enardecido por las movilizaciones católicas en el país, convocadas por la Jerarquía contra el "comunismo"; en fin, la revolución cubana y, desde luego, la expansión de la educación superior, universitaria, tecnológica y la emergencia de los estudiantes. Fue en ese cuadro que surgió entonces la gran movilización de protestas de profesionales de clase media urbana, que convirtió al mundo urbano en el centro de los conflictos. Aunque se trataba de un desarrollo previsible, prácticamente inevitable, la persistencia del movimiento del 68 no produjo en el Estado la inclusión masiva de fuerzas nuevas; al contrario, se convirtió en un pretexto para justificar el recurso incomprensible a la violencia desmedida, con el pretexto de salvaguardar la realización de los Juegos Olímpicos de México-68 que, por cierto, se convirtieron en el emblema de una sociedad eficaz y competente.

Pero para entonces el profundo cambio social había modificado ya las expectativas y demandas ciudadanas. En ese cuadro, los movimientos sociales habían sido generados, precisamente, por los efectos del proceso de desarrollo impulsado por el régimen mismo; efectos vinculados a la consecuente expansión y diversificación de mercados, demandas e intereses. La persistencia de la insatisfacción se vio nutrida por la negativa a entenderlos y atenderlos: sólo una reforma profunda que incluyera a los nuevos sectores sociales podía despejar sus causas. Era inevitable, las nuevas realidades estructurales reclamaban un nuevo enfoque, pero los reflejos y las inercias generaron un lento, titubeante y tardío, aunque sostenido: proceso de reforma del Estado que maduró, después, a lo largo de los años setenta, ochenta y noventa; y alcanzó su punto culminante a fines de siglo con la fractura del monopolio del poder detentado por el partido dominante por décadas. En efecto, con la conformación de una cámara plural, en la que había desaparecido el mando hegemónico sostenido por la solidez del control mayoritario, se impuso la construcción de acuerdos como mecanismo 
inevitable para reconstruir y reformar el marco político-constitucional. Este proceso continúa, con nuevos nombres, y es hoy conocido por ser el ingrediente decisivo de las "reformas estructurales", ajustes normativos y diálogos que tomaron con López Portillo el nombre de "reforma política" y, posteriormente, con De la Madrid, el de "Reforma del Estado". Se trataba no de establecer la nueva cimentación del mismo monopolio hegemónico, sino de desarrollar las instituciones y procesos electorales que, en un clima de acuerdos, trajeran como fruto un sistema participativo de representación ciudadana, consentido y plural. Este proceso se insertó en reformas constitucionales que sometieron al régimen a pruebas de fuego desde la crisis de 1982, como una sociedad convocada por López Portillo a prepararse "a administrar la abundancia", se vio arrinconada a voltear al exterior, cambiar de métodos y dejarse conducir, como condición para obtener créditos para pagar sus nóminas y evitar el colapso del PIB; apremio que le impuso firmar cartas de intención con el Fondo Monetario Internacional (FMI) y la asunción de una política, "global", en la cual el manejo supervisado de la economía, buscara el "sano equilibrio" de las finanzas públicas, de forma de poder alcanzar un desarrollo estable. La paradoja se hizo presente: se adoptó la "Reforma del Estado", pero ésta expresó la derrota de la tesis del Estado interventor y el triunfo de las tesis neoliberales, desde la globalización hasta la liberalización de la economía.

Se sobreponen entonces dos conceptos totalmente distintos de la "Reforma del Estado", que expresaban, uno, la reforma para democratizar el sistema, cambiar un régimen monopolítico en un régimen plural, un régimen autoritario en un régimen democrático; y asumir la disposición a estallar el paquete completo de las reformas democráticas; y el otro, la reforma para generar un nuevo concepto de convivencia productiva, esta vez orientada por los mercados no por el gobierno, y operada por las fuerzas de la producción, no por los administradores de la doctrina estatal; propuesta que recurrió a la adopción como divisa de la expresión de "Reforma del Estado". ¿Qué quería decir esta Reforma del Estado? Significaba, en pocas palabras, quitarle al Estado sus tareas de conductor de la economía y autor de las grandes iniciativas políticas de Estado inversionista, regulador, interventor; para convertirlo en un garante de la seguridad pública, el orden, la seguridad; la presencia en México de las finanzas y los mercados mundiales. El Estado "interventor" se convirtió en Estado "modesto", un Estado resignado a operar el gran proceso de privatización del sector público, a abandonar su injerencia determinante en el mercado, en el sector primario, en 
las clases medias bajas y, en los hechos, a administrar con eficacia una sociedad informal, desempleada y, en ciertos sectores, reorganizada por el crimen.

Hoy se convierte en una transición ordinaria, lo que fue una modificación de escala, de largo aliento, que tuvo sus primeras expresiones, muy tímidas, con López Portillo, quien paradójicamente concluyó su mandato con la estatización de la banca, que era precisamente lo que él mismo se había propuesto no hacer: en lugar de "liberalizar", "nacionalizó" la banca, decisión revertida ocho años más tarde y muy debatida aún en el presente. Por otro lado, "privatizar" o "liberalizar", eran referencias duras a las acciones claves para alcanzar un objetivo resumido en la adopción de una expresión fantástica: "el adelgazamiento del Estado"; de un Estado "obeso". Con todo, era preciso hacerlo en el cuadro de un conjunto de políticas públicas cruciales que implicaban abandonar la responsabilidad del Estado nada menos que frente a la desigualdad y la exclusión.

Así ocurrió. Según una de las caricaturas adoptadas entonces (1982) por el aliento liberalizador crítico, no tenía nada que hacer el Estado en la producción de "bicicletas" o de refrescos; aunque sí tenía muchas cosas que ver con temas hoy cruciales, como el de la energía, particularmente a la luz del texto del artículo 27. Es cierto, hoy el liberalismo admite, en medio de incontables matices, que la acción del Estado es fundamental en tareas tales como la educación, la viabilidad institucional de las finanzas públicas nacionales; en fin, con la apertura de oportunidades a los sectores sociales hoy "perdidos". Hay una reforma del Estado que se está enfrentando aún hoy a la crisis resultante precisamente de las privatizaciones; a los efectos devastadores del abandono de responsabilidades en materia de articulación social: en esas cuestiones no puede haber vacíos; cuando el Estado se retira de un espacio, inevitablemente lo ocupan otras fuerzas. Desde luego, no podemos ignorar otro aspecto, que es el de la viabilidad financiera de la administración pública. Gravita sobre la economía el peligro permanente de una terrible crisis, similar a la que confrontan los Estados europeos paralizados por la protesta y el desacuerdo, generados por la crisis y la austeridad, como en España o Grecia. La tarea es ardua: la racionalidad económica no implica necesariamente aceptar la anomia ni el colapso de la solidaridad. Pensarlo así equivaldría a proponer un concepto de reforma del Estado diferente al que hemos expuesto.

Desde esa perspectiva, se entrevén otros temas de la reforma del Estado. Estos son los desafíos y problemas registrados ya, que no tienen aún respuesta alguna. Me refiero a los cambios de la estructura social. México pasó de ser un país eminentemente rural (cuando se dio la Revolución, el 79 por ciento de la Población Económicamente Activa (PEA) trabajaba en el sector primario; es decir, 
en el mundo rural y, muy menor medida, en la minería. En el momento actual, en contraste, dicho sector es atendido apenas por el 14 por ciento de la PEA. Añadamos la imagen complementaria: cuando estalló la Revolución de 1910, el comercio, las finanzas y los servicios empleaban el 9 por ciento de la PEA; hoy, en dicho sector, trabaja casi el 60 por ciento. El sector secundario, el industrial, por su parte, creció de una manera espectacular primero, pero registró después un retroceso progresivo significativo: hoy recibe al 25 por ciento de la PEA. ${ }^{17}$

Hoy nuestra sociedad es urbana y demanda servicios: transporte, abasto y comercio; prestaciones sociales y salud, educación y seguridad; esparcimiento, arte y cultura; y no sabemos, después de tres años de reformas intensas, cómo va a ser administrada, cómo quedará finalmente constituido su marco legal. Estamos frente a un gran enigma. Por eso destaca hoy, a pesar del esfuerzo reformista ya emprendido, la tarea de hacer una gran reforma del Estado: la reforma urbana, laboral, estructural; la reforma por la recuperación del Estado.

Contamos en suma con tres conceptos distintos. Uno, la reforma política; esto es, la asunción plena de un orden republicano y democrático, partidista, electoral; compartido y legitimado por la participación de los ciudadanos. Otro, el de la segunda reforma, la que nos ha insertado en la globalización; peor aún, la que nos ha convertido no en una economía plenamente independiente, sino en el eslabón más débil del mercado común de América del Norte. Conviene recordar, hoy, cómo asumimos la globalización. Tengamos presente un hecho decisivo: la tercera parte del PIB tiene en México su origen en el comercio exterior. En efecto, uno de cada tres pesos, cuya circulación se registra en México proviene del comercio exterior. Se trata de un renglón inmenso: implica en variadas proporciones servicios, turismo, mano de obra, alimentos, manufacturas, petróleo, y aún, el mercado mundial de las drogas, renglón en el cual el país ocupa, infortunadamente, una posición destacada. Nuestra sociedad es simultáneamente una sociedad inserta en la globalización, pero también, como nunca, una sociedad desigual, fragmentada, excesivamente informal: más de una cuarta parte del Producto de la economía se origina en el sector informal, ${ }^{18}$ y más de la mitad de la fuerza de trabajo está en dicho sector.

${ }^{17}$ El porcentaje de la PEA, de acuerdo a los indicadores de ocupación y empleo al cuarto trimestre de 2015 del INEGI, se distribuye de la siguiente manera: sector primario: 14 por ciento, sector secundario, 25 por ciento, y sector terciario, 60 por ciento. El Producto Interno Bruto, por su parte, se conformó, al cuarto trimestre del 2015, de acuerdo con el INEGI, de la siguiente forma: 4 por ciento, sector primario; 31 por ciento, sector secundario, y 60 por ciento, sector terciario.

${ }^{18}$ INEGI, “Medición de la economía informal, 2014", México, 2014. 
Estábamos celebrando en 1994 los primeros "festejos" del quinto siglo del inicio de la ocupación del continente americano, del "Descubrimiento de América" (evento denominado hoy pomposamente "El Encuentro de Dos Mundos", expresión inexacta que pretende esquivar la brutalidad con la que fueron sometidas y reconstruidas las sociedades autóctonas "descubiertas" y sometidas entonces). En los hechos, los europeos vinieron a "ocupar" las tierras de América, las colonizaron en muy diversas circunstancias y echaron a andar un proceso de sometimiento que duró al menos tres siglos; esto es, desde el inicio del siglo XVI, con la gradual invasión del Caribe y el continente, hasta la culminación decimonónica de los procesos de independencia. ${ }^{19}$

El primero de enero de 1994, un año y tres meses después del quinto centenario del "Descubrimiento de América", estalló en México el movimiento zapatista. Cinco siglos de plazo habían sido insuficientes para resolver los problemas de integración, participación social, viabilidad económica, integración cultural, y autonomía de los componentes del Estado mexicano. En ese orden, se antoja imprescindible hoy una gran reforma de Estado, una reforma que asegure la permanencia y favorezca el florecimiento de las lenguas indígenas, supere la fragmentación de nuestro país en regiones, y la sustituya mediante la integración, por la vía de un indispensable pluralismo; que permita responder a la emergencia de una realidad histórica: el poblamiento de un territorio inmenso que propicia la urbanización sin planeación de conjunto, como lo ilustran las zonas metropolitanas, la edificación paralela y asilada de ciudades y la destrucción de paisajes, ciudades donde se yuxtaponen los poderes municipales, estatales y federales, con distintas reglas del juego y distintos marcos jurídicos propios, sometidos, todos, finalmente a la hegemonía del orden de poder central, superior. Esa situación, que implica vivir los extremos de la convivencia metropolitana, es compartida en la actualidad por más de un tercio de los mexicanos. ${ }^{20}$ Es también un ejemplo de las demandas que pesan de manera apremiante en la agenda contemporánea de la reforma del Estado, aunque no hayan sido objeto de atención. Podríamos igualmente hacer otra larga lista de problemas antiquísimos y similares, que seguimos discutiendo,

${ }^{19}$ Recuérdese que la independencia de Cuba se alcanzó hasta 1895, y la de Puerto Rico en 1897; y que en la actualidad, se registran 11 territorios no autónomos en el continente americano, así sean islas, cuyos procesos de descolonización siguen abiertos: Bermudas, Islas Turcas y Caicos, Islas Caimán, Islas Vírgenes de Estados Unidos, Islas Vírgenes Británicas, Anguila, Montserrat, Tokelau, Samoa Americana, Pitcairn, y las Islas Malvinas.

${ }^{20}$ Cfr. SEDESOL-CONAPO-INEGI, Delimitación de las zonas metropolitanas de México 2010, México, 2012. 
sin la capacidad de resolverlos, como la agresión a los bosques, el deterioro de los recursos naturales y el uso abusivo del agua.

En ese tema destaca, precisamente, el desajuste entre los grandes objetivos nacionales y los medios puestos al servicio de su realización.

La Constitución ha sido el instrumento fundamental para crear, in petto, realidades fundamentales solamente imaginarias. En ese orden, las aspiraciones, así sean imprecisas y remotas, se atienden por el expediente de reformas puramente formales al aparato jurídico. La Constitución ha sido adicionada muchas veces para modificar un artículo y establecer pomposamente, normas que no se cumplen como ha ocurrido con la igualdad de los géneros, la igualdad entre el hombre y la mujer; así se trate de una realidad no solamente formal, imaginaria; sino distante. Desde 1974 la Constitución estableció la igualdad entre el hombre y la mujer; sin embargo, en la Cámara de Diputados, el número de legisladoras no alcanzó el 10 por ciento. Esta situación se mantuvo vigente hasta 1982, cuando el total de mujeres rebasó ese porcentaje. Es entonces que la Constitución, el imaginario social, descubre a la mujer como un ser humano pleno, con iguales, o incluso mejores derechos que el varón, fundado en el hecho de que ella atiende una responsabilidad dual: por una parte, familiar, social y, por la otra, el trabajo, el desarrollo y realización de una vocación humana propia, el cumplimiento de un proyecto personal, acaso profesional; el acceso al derecho a encarnar una vocación propia. Hoy estamos también descubriendo otros sujetos de derechos igualmente cruciales: la tercera edad, los niños, los "diferentes"... Es obvio: el rezago en materia de reforma del Estado es aún insondable.

¿Cómo se ha planteado este nudo de temas con tantas aristas? ¿Por qué se advierten rezagos profundos en temas de los que la sociedad se ha ocupado por décadas? Entre los temas centrales destaca, acaso como el más visible de ellos, en el ámbito de la política, el tema de la democratización. Recordemos que nuestro país vivió con una gran esperanza, que registran la historia y la literatura, el salto cualitativo que se produjo en el lenguaje, en las expectativas y en las reivindicaciones políticas, en México, como efecto de la primera Reforma Política que parecía verdadera, en la que participaron, por cierto, prácticamente todas las fuerzas políticas, incluso de extrema derecha y de extrema izquierda, en 1977, cuando se reestructuró la Comisión Federal Electoral y se establecieron vías diversas para que las minorías incrementaran sus oportunidades para obtener diputados federales. 
Son sobrecogedoras las minutas de la Cámara de Diputados que registran la dinámica que esta reforma desató. Con todo, la reforma política seguía siendo insuficiente. En 1984 se introdujo una nueva serie de cambios que incrementaron notablemente la participación de las oposiciones en la integración de la Cámara de Diputados y se fortaleció el papel de la entonces llamada Comisión Federal Electoral. Sin embargo, la elección presidencial cambió totalmente el tono del lenguaje político. Los candidatos de oposición, Clouthier y Cárdenas, denunciaron lo que consideraron un fraude. Durante el sexenio 1988 y 1994 se llevaron a cabo tres reformas electorales profundas; impuestas, la primera, en 1990, por la inagotable controversia que generó el resultado de la elección presidencial. El PAN la asumió, aunque con reservas, el PRD fundado formalmente en mayo de 1989, se negó a participar en una reforma insatisfactoria, aunque participó en los comicios de 1991. La segunda, en 1993 como un preparativo de la elección federal del siguiente año para atender las inconformidades generadas por la ley anterior y, sobretodo, para satisfacer los requisitos planteados por diversos partidos, básicamente el PRD, como condición para aceptar la legitimidad del marco jurídico del proceso electoral; en fin, en 1994 se llevó a cabo una tercera reforma electoral, determinada por las más inesperadas circunstancias: el levantamiento en Chiapas el primero de enero de ese año, la incertidumbre que generó el asesinato y la sustitución de Luis Donaldo Colosio Murrieta; y, particularmente el clima de desconfianza y reserva que los acontecimientos de dicho año habían generado. La reforma modificó particularmente la estructuración del Instituto Federal Electoral y la renovación de sus integrantes; como también la concertación de acuerdos sobre la integración del nuevo Consejo General del IFE, de manera que ofreciera confianza a los partidos participantes.

Las nuevas reglas incrementaron, también, las garantías de equidad del proceso y equilibraron el acceso de partidos y candidatos a los recursos públicos. Como consecuencia, y a pesar del clima político dominante durante el año, la elección fue un ejercicio reconocido y los resultados de la elección presidencial no fueron cuestionados. Hubo una conciencia compartida de que la elección había sido limpia.

A pesar de esta circunstancia, la gestión de Ernesto Zedillo, electo Presidente de los Estados Unidos Mexicanos, en 1994, fue extraordinariamente compleja. Por una parte, inició con uno de los peores episodios de la ya crónica crisis económica de México: el "error de diciembre". Una sexta parte del PIB se perdió como resultado de la crisis consecuente. Por otra parte, el proceso sostenido de ascenso de las oposiciones no sólo se mantuvo, en rigor a un ritmo más 
elevado. El Cuadro 1 da muestra de ello. Ciertamente la reforma de 1994 no impidió que el candidato del PRI ganara la elección y su partido conservara la mayoría en las dos Cámaras federales. Conviene recordar que el IFE había sido reestructurado y que el Tribunal Electoral del Poder Judicial de la Federación había sido igualmente transformado para convertirlo en garante de las reglas de equidad y en el acceso a los recursos electorales. La elección de Zedillo fue reconocida. Los candidatos de oposición, Diego Fernández de Ceballos del PAN y Cuauhtémoc Cárdenas Solórzano del PRD, se abstuvieron de impugnar la elección. Prevaleció la conciencia compartida de que la elección había sido legal y limpia, aunque fundada en una ley inequitativa.

El inicio de la gestión de Ernesto Zedillo fue excepcionalmente difícil, debido al estallamiento de la crisis económica, crisis producida y conocida por los "errores de diciembre", registró efectos gigantescos: la pérdida de una sexta parte del PIB y la súbita improvisación de una nueva "reforma estructural", también señalada como la "reforma del Estado". La respuesta del nuevo gobierno consistió en poner en marcha un proceso sistemático entre cuyos objetivos estaba el establecimiento de las bases para regularizar los altibajos y las fracturas y evitar las crisis económicas recurrentes, crisis que debían ser, en el peor de los casos, previstas y reguladas. El resultado fue positivo: se blindó la economía y se estabilizaron las variables económicas. Pero también fue costoso: en rigor se detuvo el crecimiento económico con el resultado que todos conocemos. El presidente Zedillo alcanzó tasas de crecimiento apenas superiores al tres por ciento; mientras que en los años que van del 2000 al 2012 el crecimiento apenas alcanzó el dos por ciento, mientras que durante 2015 se registró un crecimiento de apenas el 2.5 por ciento.

Zedillo ofreció una reforma electoral que hizo posible a las oposiciones ganar la elección legislativa de 1997 y la Presidencia de la República en el año 2000. Conviene indicar, por lo demás, que la vinculación económica con Estados Unidos implicó, abrir las puertas al sector maquilador lo que ha significado costos políticos escandalosos, como la renuncia a la soberanía en el control de dichas empresas y el pago de salarios comparativamente muy inferiores a los vigentes en Estados Unidos. Como sabemos, hoy la economía mexicana sufre graves insuficiencias. Los ingresos de los trabajadores son comparativamente muy bajos en contraste con los montos pagados al cruzar la frontera. El crecimiento del sector informal ha sido incontenible. Hoy sabemos que más de la mitad de los trabajadores mexicanos están sometidos a un régimen de trabajo informal (57.7 por ciento). 
Ese es el trasfondo en el que hoy se perfila el tema de la gobernabilidad. Como lo han demostrado los efectos de la política económica en curso no se registra un incremento sensible del PIB, mismo que asciende a 2.5 por ciento y el proceso de concentración del ingreso sigue su curso. Es de advertirse el pesimismo vigente en el ámbito de los medios de comunicación, del económico y, muy particularmente, en las expectativas políticas. Hoy la gobernabilidad no puede ser alcanzada sino como resultado de un gran acuerdo nacional que impida el enfrentamiento, el desbordamiento de la violencia y del crimen y franquee la vía en que en el ámbito de la economía y la política encontremos una salida satisfactoria, constitucional y democrática. Esa es hoy la tarea de la gobernabilidad: una gobernabilidad que permita, finalmente, alcanzar la interminable transición mexicana.

Finalmente, destaco la colaboración de Héctor Zamitiz, Gloria Luz Alejandre, Julio Bracho, César Hernández y Fernando Ayala en la integración de este libro. Sus capítulos reflejan que, durante las últimas décadas, el sistema político mexicano, particularmente el presidencialismo, ha evolucionado de uno de naturaleza vertical y autoritario hacia uno de naturaleza discresional, fundado en las amplias competencias que le han sido otorgadas por la Constitución, desde la perspectiva de la evolución de sus diversos componentes: los poderes, los órdenes de gobierno, y las fuerzas y los movimientos sociales y en el marco de las reformas estructurales. En especial, el texto de Fernando Ayala pone de relieve la naturaleza y perspectivas de los grupos de interés-presión en México, mediante un estudio de caso. Agradezco a la Dirección General del Personal Académico de la Universidad Nacional Autónoma de México su decidido apoyo para realizar labores de investigación que se concretan en esta obra.

CUADRO 1. PARTIDOS POLÍTICOS QUE GOBERNARON LAS ENTIDADES FEDERATIVAS DURANTE LOS PERIODOS PRESIDENCIALES DE 1994-2018

\begin{tabular}{|c|c|c|c|c|}
\hline \multirow{2}{*}{ Estado } & $1994-2000$ & $2000-2006$ & $2006-2012$ & 2012-2018 \\
\cline { 2 - 5 } & $\begin{array}{c}\text { Ernesto Zedillo } \\
\text { Ponce de León }\end{array}$ & $\begin{array}{c}\text { Vicente Fox } \\
\text { Quesada }\end{array}$ & $\begin{array}{c}\text { Felipe Calderón } \\
\text { Hinojosa }\end{array}$ & $\begin{array}{c}\text { Enrique Peña } \\
\text { Nieto }\end{array}$ \\
\hline Aguascalientes & PAN & PAN & PAN & PAN \\
\hline Baja California & PAN & PAN & PAN & PAN \\
\hline Baja California Sur & PRI & PRD & PRD & PAN \\
\hline Campeche & PRI & PRI & PRI & PRI \\
\hline Colima & PRI & PRI & PRI & PRI \\
\hline
\end{tabular}




\begin{tabular}{|c|c|c|c|c|}
\hline \multirow[t]{2}{*}{ Estado } & $1994-2000$ & 2000-2006 & 2006-2012 & 2012-2018 \\
\hline & $\begin{array}{c}\text { Ernesto Zedillo } \\
\text { Ponce de León }\end{array}$ & $\begin{array}{c}\text { Vicente Fox } \\
\text { Quesada }\end{array}$ & $\begin{array}{c}\text { Felipe Calderón } \\
\text { Hinojosa }\end{array}$ & $\begin{array}{c}\text { Enrique Peña } \\
\text { Nieto }\end{array}$ \\
\hline Chihuahua & PAN & PRI & PRI & PAN \\
\hline Durango & PRI & PRI & PRI & PAN-PRD \\
\hline Guanajuato & PAN & PAN & PAN & PAN \\
\hline Guerrero & PRI & PRI & PRD & PRI \\
\hline Hidalgo & PRI & PRI & PRI & PRI-PVEM-PANAL \\
\hline Jalisco & PAN & PAN & PAN & PRI \\
\hline México & PRI & PRI & PRI & PRI \\
\hline Michoacán & PRI & PRD & PRD & PRD \\
\hline Morelos & PRI & PAN & PAN & PRD \\
\hline Nayarit & PRI & PAN & PRI & PRI \\
\hline Nuevo León & PAN & PAN & PRI & Independiente \\
\hline Oaxaca & PRI & PRI & PRI & $\begin{array}{l}\text { PRI-PVEM- } \\
\text { PANAL }\end{array}$ \\
\hline Puebla & PRI & PRI & PRI & $\begin{array}{c}\text { PAN-PT-PANAL- } \\
\text { CPP-PSI }\end{array}$ \\
\hline Querétaro & PAN & PAN & PRI & PAN \\
\hline Quintana Roo & PRI & PRI & PRI & PAN-PRD \\
\hline San Luis Potosí & PRI & PAN & PRI & PRI \\
\hline Sinaloa & PRI & PRI & PRI & $\begin{array}{l}\text { PRI-PVEM- } \\
\text { PANAL }\end{array}$ \\
\hline Sonora & PRI & PRI & PAN & PRI \\
\hline Tabasco & PRI & PRI & PRI & PRD \\
\hline Tamaulipas & PRI & PRI & PRI & PAN \\
\hline Tlaxcala & PRI & PRD & PAN & $\begin{array}{l}\text { PRI-PVEM- } \\
\text { PANAL-PS }\end{array}$ \\
\hline Veracruz & PRI & PRI & PRI & PAN-PRD \\
\hline Yucatán & PRI & PAN & PRI & PRI \\
\hline Zacatecas & PRI & PRD & PRD & PRI \\
\hline Ciudad de México & PRD & PRD & PRD & PRD \\
\hline
\end{tabular}

Fuente: elaboración propia con información de las páginas de los institutos electorales locales. 


\section{Fuentes}

Arregui Zamorano, Pilar, La Audiencia de México según los visitadores (siglos XVI y XVII), México, Instituto de Investigaciones Jurídicas, Universidad Nacional Autónoma de México, 1981.

Ávila, Alfredo y Jáuregui, Luis, "La disolución de la monarquía hispánica y el proceso de independencia", en Nueva Historia General de México, México, El Colegio de México, 2010.

Barragán, José, "Los diputados novohispanos en las Cortés de Cádiz", en Barceló Rojas, Daniel y Serna de la Garza, José Ma. (coords.), Memoria del Seminario Internacional: Conmemoración del Bicentenario de la Constitución de Cádiz. Las ideas constitucionales de América Latina, México, Instituto de Investigaciones Jurídicas, Universidad Nacional Autónoma de México-Senado de la República, 2013.

Chiva Berltrán, Juan, El triunfo del virrey: glorias novahispanas. Origen, apogeo y ocaso de la entrada virreinal, España, PublicacionEs de la Universitat Jaume I, 2012.

Delgado-Iribarren, Francisco, "La Noche Triste: Hernán Cortés y sus hombres sucumben a la venganza azteca", ABC. 21 de diciembre de 2013.

Escalante Gonzalbo, Pablo, "El México antiguo", en Nueva Historia Mínima de México, México, El Colegio de México, 2004.

Escalante Gonzalbo, Pablo, "El posclásico en Mesoamérica", en Nueva Historia General de México, México, El Colegio de México, 2010.

Fix-Fierro y Valadés, Diego, "Hacia la reordenación y consolidación del texto de la Constitución Política de los Estados Unidos Mexicanos de 1917. Estudio introductorio". Disponible en: <http://www2.juridicas.unam.mx/constitucion-reordenadaconsolidada/files/Estudio_Introductorio.pdf>.

Fix-Fierro, Héctor, "Engordando la Constitución", Nexos, febrero de 2014. Disponible en: <http://www.nexos.com.mx/?p=18375>.

Hausberberger, Bernd y Mazín, Óscar, "Nueva España: los años de autonomía”, en Nueva Historia General de México, México, El Colegio de México, 2010.

INEGI, Medición de la economía informal, 2014, México, 2014.

Nalda, Enrique, "El Clásico en el México Antiguo", en Nueva Historia General de México, México, El Colegio de México, 2010.

Paoli Bolio, Francisco José, La Constitución de Cádiz en Iberoamérica, México, Instituto de Investigaciones Jurídicas, Universidad Nacional Autónoma de México, 2016.

SEDESOL-CONAPO-INEGI, Delimitación de las zonas metropolitanas de México 2010, México, 2012. Valle Arizpe, Artemio de, Virreyes y virreinas de la Nueva España: tradiciones, leyendas y sucedidos del México virreinal, México, Porrúa, 2000.

Velásquez García, Erik, "Los habitantes más antiguos del actual territorio mexicano", en Nueva Historia General de México, México, El Colegio de México, 2010.

Villalpando, José Manuel, Historia de México a través de sus gobernantes, México, Planeta, 2008.

Zoraida Vázquez, Josefina, "De la Independencia a la Consolidación Republicana", en Nueva Historia Minima de México, México, El Colegio de México, 2004. 


\section{EL PACTO POR MÉXICO EN LOS CONTORNOS DEL PRESIDENCIALISMO}

\section{Héctor Zamitiz Gamboa}

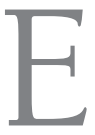

l Pacto por México debe considerarse una exitosa decisión política que tuvo por objeto instituir un mecanismo de acuerdo, entre la presidencia de la República y las dirigencias de los partidos Acción Nacional (PAN) y de la Revolución Democrática (PRD). Por esta razón, debe ser considerado también una innovación que se propuso modificar algunos obstáculos, para lograr una cooperación más eficaz entre los actores políticos en nuestro país, pues logró la aprobación por el Congreso de reformas constitucionales que para muchos eran necesarias para el desarrollo nacional, pero que para otros no debieron de haberse aprobado ni en los términos, ni en la forma como se hizo.

El Pacto por México permitió definir una agenda común entre el gobierno, el PAN y el PRD a partir de sus propias agendas y logró ser eficaz al superar las dificultades que la alternancia y los gobiernos divididos habían generado en las relaciones del Ejecutivo con el Legislativo, pues este mecanismo de acuerdo se inscribe en la presencia de gobiernos sin mayoría en el Congreso.

Conviene recordar que a partir de 1997 la pluralidad del sistema de partidos modificó la relación entre el Ejecutivo y el Legislativo, y fue a partir de la alternancia en la presidencia de la República en el 2000, cuando el primero experimentó una pérdida del dominio que mantenía sobre la producción legislativa y, aun cuando continúo proponiendo iniciativas de reforma, éstas fueron discutidas y modificadas por ambas cámaras en el Congreso.

En este sentido el Pacto por México puede verse en el proceso político y en el cambio institucional en México desde dos perspectivas: a partir del pluralismo que coexiste con el sistema presidencial y reconocer sus fortalezas como mecanismo de acuerdos y coaliciones legislativas, o como una exitosa estrategia y 
operación política para impulsar temas prioritarios de la agenda presidencial y con ello fortalecer al Ejecutivo en el ejercicio de sus facultades en un contexto sin aparentes mayorías legislativas.

Al optar por la segunda perspectiva nos proponernos hacer un balance de la eficacia de este acuerdo político, pero como una variante del sistema presidencial y sus implicaciones, para lo cual destacamos los cambios efectuados en el Partido Revolucionario Institucional (PRI), las prioridades de la agenda del Presidente, la construcción de una agenda legislativa en su mayoría controlada por el primero, la modificación de las relaciones entre el Ejecutivo y el Legislativo como producto de los procesos legislativos y, por último, explicar, por qué el Pacto por México se inscribe en lo que han calificado algunos analistas como la "agenda presidencialista".

\section{La adaptación del Partido Revolucionario Institucional al nuevo ciclo reformas}

El Partido Revolucionario Institucional (PRI) regresó a la Presidencia de la República en el 2012, con un inicio discutido y generando expectativas en un sentido ambivalente: o jugaba a la restauración del viejo régimen con nuevo rostro, o ensayaba la recuperación de la rectoría del Estado a partir de acuerdos cupulares con desembocadura en la consolidación de la democracia.

Es posible que Enrique Peña Nieto y los grupos aliados que tomaron el poder en el 2012, se propusieron restaurar el régimen político que con la alternancia se suponía superado, aunque hablar de un proyecto restaurador no es sencillo, pues se deben estudiar distintas variables, tales como los resultados de la elección federal intermedia, de las elecciones de 2016 y, en particular, de las elecciones presidenciales de 2018.

Aunque el objetivo del presidente Enrique Peña Nieto fue que el "Pacto por México" se firmara antes de su toma de posesión, por las diferencias internas en el PRD, el Pacto fue hecho público un día después, es decir el 2 de diciembre de 2013 en una ceremonia celebrada en el Castillo de Chapultepec, encabezada por el Presidente Enrique Peña Nieto, acompañado de los presidentes de los

\footnotetext{
${ }^{1}$ Véase, Espinoza Toledo, Ricardo, "El estancamiento del presidencialismo mexicano: la relación entre los poderes Ejecutivo y Legislativo", en Escamilla Cadena, Alberto y Becerra Chávez, Pablo Javier (coords.), El presidencialismo mexicano durante los gobiernos de la alternancia, México, UAM, IztapalapaMiguel Ángel Porrúa, 2013, pp. 33-34.
} 
partidos pactantes: María Cristina Díaz (PRI), Gustavo Madero (PAN) y Jesús Zambrano (PRD) y por los demás integrantes del grupo negociador.

En el plano institucional el hecho de que el presidente lograra acordar un pacto con los partidos de oposición, lo convirtió aparentemente en el árbitro al que se someterían los actores, pues jugó, en el destino de este episodio, no sólo su capacidad, sino también la velocidad para impulsar las transformaciones en los dos primeros años de su gestión. En esta etapa destacó su entereza para verse y reconocerse disminuido en aceptación y popularidad, pero con la oportunidad de fortalecerse en el ejercicio de gobierno.

Sin embargo, para no pocos observadores, a esta nueva alternancia la acechaban mil y un peligros: la inseguridad, los poderes fácticos, la falta de crecimiento económico, pero sobre todo, no perder de vista que el régimen presidencialista se encontraba agotado y que era un riesgo pretender tan sólo aplicar nuevas formas a viejos problemas, como es el de la corrupción.

El PRI que acompañó a Enrique Peña Nieto los dos primeros años de gobierno, periodo de las reformas constitucionales y legales del Pacto por México, tuvo una reforma interna en el mes de marzo de 2013, que fue promovida por el propio presidente Peña Nieto, confirmando con esto la interrelación entre el poder constitucional y el poder partidario, enraizada en los incentivos institucionales implícitos en el tipo de presidencialismo al que hasta ahora ha pertenecido el caso mexicano. ${ }^{2}$

Enrique Peña Nieto encabezó la XXI Asamblea Nacional del PRI el 4 de marzo de 2013 en el 84 aniversario de la fundación del partido, en la que fueron avalados los nuevos estatutos que contemplan que sea el titular del poder Ejecutivo quien encabece la Comisión Política Permanente. Según la reforma, éste sería el máximo órgano de decisión del partido y estaría integrado por 54 priistas, incluidos gobernadores, líderes parlamentarios en el Senado y en la Cámara de Diputados y dirigentes de los distintos sectores. En la nueva redacción de los estatutos se establece que la Comisión Política Permanente será la que establezca el diálogo con los otros partidos políticos para favorecer la gobernabilidad, además de que hará recomendaciones sobre los temas prioritarios en el Congreso de la Unión. Otros cambios en los documentos internos del PRI previeron la posibilidad de modificar el impuesto al valor agregado (IVA) y dar entrada a la iniciativa privada en el sector energético.

${ }^{2}$ Consúltese, Mainwaring, Scott y Shugart, Mattew Soberg (comps.), Presidencialismo y democracia en América Latina, Buenos Aires, Paidós, 2012, p. 16. 
Respecto a la postulación de candidatos, el PRI eliminó el candado que impedía que alguien aspirara a ser nominado para una gubernatura, la Jefatura de Gobierno del DF o la Presidencia de la República si antes no había ocupado un puesto de elección popular a través de las siglas del PRI. Incluso abrió la puerta para que ex priistas puedan retornar al partido y ser postulados como candidatos, además de nominar a abanderados externos. El PRI también formalizó las encuestas como método de selección de candidatos.

\section{Las prioridades legislativas del gobierno Peña Nieto: su inserción en la agenda del Pacto por México}

El primer impacto del resultado electoral del triunfo de Enrique Peña Nieto en las urnas se reflejó en las prioridades legislativas de su gobierno. Sus primeras iniciativas ante el Congreso dieron cuenta de una agenda reactiva, desarticulada. Tales fueron los casos de las propuestas atoradas hasta febrero de 2015 por sus opositores en el Congreso, en materia de transparencia, rendición de cuentas y combate a la corrupción. La reforma a la Ley Orgánica de la Administración Pública causó polémica por el regreso a la Secretaría de Gobernación de las facultades en materia de seguridad pública y la elevación por acuerdo presidencial de su titular a la condición legal de coordinador de gabinetes. ${ }^{3}$

En su Mensaje a la Nación, el día de su toma de posesión el $1^{\circ}$ de diciembre de 2012, Enrique Peña Nieto señaló como atributos de su gobierno, que éste sería abierto y responsable, pero sobre todo enfatizó que impulsaría una presidencia democrática ${ }^{4}$, además de prometer una democracia eficaz y de reconocer que el Estado había cedido importantes espacios en los que la inseguridad y la violencia habían robado la paz y la libertad de diversas comunidades del territorio nacional. Propuso 5 ejes de gobierno: a) "Un México en paz"; b) "Un

\footnotetext{
${ }^{3}$ La falta de acuerdo en el Senado obligó al presidente Peña Nieto a mantener el mismo organigrama de Felipe Calderón. Fue hasta después de su toma de posesión que pudo contar con el "rediseño institucional" que propuso, aun cuando a la fecha todavía se encuentra incompleto: la desaparición de la Secretaría de la Función Pública, cuyas funciones y facultades serían transferidas a la Secretaría de Hacienda y Crédito Público, y la creación de la Comisión Nacional Anticorrupción, instancia que absorbería la mayoría de las atribuciones de la Secretaría de la Función Pública. Véase, Martínez, Martha, "Nuevo gobierno, mismo diseño", Suplemento Enfoque del Periódico Reforma, 2 de diciembre de 2012, p. 6.

${ }^{4}$ El 20 de mayo de 2012, como candidato del PRI a la presidencia de la República, Enrique Peña Nieto dio a conocer un "Manifiesto por una presidencia democrática", diez días después de que fuera increpado por estudiantes en la Universidad Iberoamericana y surgiera el movimiento \#YoSoy132.
} 
México incluyente"; c) "Un México con educación de calidad para todos"; d) "Un México próspero" y, e) "Un México, actor con responsabilidad global".

Posteriormente, informó sobre las decisiones que tomaría como titular del Poder Ejecutivo: 1) Que México viva en paz; 2) Desistirse de la controversia constitucional existente con el fin de aprobar en definitiva la Ley de Víctimas; 3) Presentar una iniciativa constitucional con el fin de contar con un sólo Código Penal y uno de Procedimientos Penales; 4) Poner en marcha la "Cruzada Nacional contra el Hambre"; 5) Crear el "Programa de Seguro de Vida para jefas de familias"; 6) Ampliar y modificar el programa "70 y más", con el fin de que los mexicanos mayores de 65 años recibieran una pensión, lo cual permitiría dar el primer paso de la creación del "Sistema de Seguridad Social Universal"; 7) Enviar al Congreso de la Unión la iniciativa para "reformar el Artículo Tercero Constitucional, y en su momento, la subsiguiente "Reforma a la Ley General de Educación"; 8) Presentar la Propuesta del "Programa Nacional de Infraestructura y Transporte 2012-2018"; 9) Iniciar la construcción del tren México-Querétaro y los proyectos de construcción del tren México-Toluca y el tren trans-peninsular Yucatán-Quintana Roo; 10) Enviar al Congreso de la Unión una iniciativa con un conjunto de reformas en materia de telecomunicaciones; 11) Enviar al Congreso de la Unión un proyecto de Ley Nacional de Responsabilidad Hacendaria y Deuda Pública; 12) Someter a consideración del Congreso de la Unión el paquete económico 2013 con cero déficit presupuestal $y, 13)$ que dicho paquete económico estableciera medidas de austeridad y disciplina presupuestal en el ejercicio del gasto público. ${ }^{6}$

Los primeros 100 días de gobierno de EPN fueron condecorados por la aprobación y el entusiasmo. Cuando asumió la presidencia del país las expectativas eran descomunales, pues como mandatario había conseguido mantener y acrecentar el capital político generado, tanto por el discurso inaugural de su gestión como por la firma, al día siguiente, del Pacto por México.

Se reconoció que el titular del Ejecutivo había tenido un acierto en el campo de la estrategia política, pues había trastocado rápidamente su imagen de un político producto de la mercadotecnia, en la de un hombre que se sentía, se presentaba y conducía como un Presidente de la República. El hecho de haber conseguido sentar en una misma mesa a las oposiciones de derecha y de izquierda con el partido en el poder, para suscribir con el gobierno un pacto, fue

${ }^{5}$ Véase, Voz y Voto, Política y Elecciones, "Enrique Peña Nieto 5 ejes, 13 decisiones. Mensaje a la nación $1^{\circ}$ de diciembre de 2012", núm. 239, pp. 35-42.

${ }^{6}$ Idem. 
el mayor logro; superior incluso, para algunos, al de la captura de la ex-lideresa del Sindicato Nacional de Trabajadores de la Educación, Elba Esther Gordillo. Tal era el desencuentro entre las fuerzas políticas y la decepción ciudadana ante ellas que, ciertamente, el sólo sentarlas al mismo tiempo y en la misma mesa a firmar un acuerdo, fue relevante. ${ }^{7}$

En este contexto, los primeros meses transcurridos desde que el presidente Peña Nieto llegó a Los Pinos constituyeron un periodo insuficiente para remontar la situación en la que su predecesor Felipe Calderón dejó al país; pero ese lapso de tiempo habría sido suficiente para formular y empezar a aplicar estrategias claras y definidas de gobierno, al menos en los ámbitos que más preocupaban y afectaban a la ciudadanía: el mal desempeño de la economía, con los graves impactos sociales que conlleva y las persistentes inseguridad y violencia que se abaten sobre la sociedad.

El primer informe de gobierno fue importante para valorar su desempeño. Por una parte se reconoció la audacia del Presidente de la República por haber consensuado con la oposición en nueve meses, más renovaciones que las obtenidas en 12 años del panismo, pero en su mensaje a pesar de haber mencionado en 68 ocasiones las palabras cambio, transparencia y reforma, nunca hizo referencia a la incómoda corrupción, lo cual era una importante ausencia, pues si se hace un seguimiento de las políticas en materia de rendición de cuentas, encontramos que todas las reformas estructurales propuestas durante su primer año de gobierno, carecían de "políticas efectivas en materia de rendición de cuentas y combate a la corrupción". 8

Esta observación es importante pues a pesar de haber incluido importantes prioridades de su gobierno en la agenda del Pacto por México, cuando el gobierno de Enrique Peña Nieto cumplía 300 días en el poder, el marco de su actuación era más de resistencia que de cambio ${ }^{9}$. Por ejemplo, las encuestas entre agosto y noviembre de 2013 reflejaron una tendencia con números malos: la aprobación y calificación del Presidente y del gobierno habían caído entre una cuarta y quinta parte; la evaluación del desempeño gubernamental en temas específicos y los augurios negativos para el futuro se elevaron. ${ }^{10}$

${ }^{7}$ Delgado, René, Periódico Reforma, 20 de julio de 2013.

${ }^{8}$ Consúltese, Aguayo, Sergio, "Cambiar", La Jornada, 4 de septiembre de 2013, p. 15.

${ }^{9}$ Véase, Delgado, René, "Cambio o resistencia”, Periódico Reforma, 2 de noviembre de 2013, p. 16.

${ }^{10}$ Cfr. Castañeda, Jorge, "Encuestas a un año", Periódico Reforma, 5 de diciembre de 2013, p. 13. 


\section{La dinámica de la negociación de las reformas}

Desde finales de noviembre de 2012, por separado, las dirigencias del PRI, PAN y PRD manifestaron su conformidad por llegar a un acuerdo político nacional, con la finalidad de aprobar las reformas estructurales pendientes y generar, al margen de sus diferencias políticas, una agenda común de trabajo. Días antes, los líderes habían iniciado con el equipo de transición del presidente electo una serie de reuniones para tal efecto.

Desde su anuncio el acuerdo tuvo sus rechazos y condicionamientos. Primero fue en las filas del PAN y luego en las filas del PRD. Los dirigentes Gustavo Madero y Jesús Zambrano no lograron consensuar completamente el acuerdo al interior de sus respectivos partidos, por el contrario, enfrentaron resistencias a la hora de implementarlo en las cámaras. ${ }^{11}$ Recordemos que el proceso electoral dejó al primero en una suerte de debacle, y al segundo, con una fractura profunda, con la separación de Andrés Manuel López Obrador en su interés de obtener el registro de Morena como partido político.

Comparado con un pacto exitoso como el de la Moncloa ${ }^{12}$ que en octubre de 1977 consolidó la transición española, el Pacto por México fue integrado por 95 acciones que comenzaron a implementarse desde el 2013. No obstante, desde el inicio de los acuerdos se observó que el pacto estaría a prueba, pues tanto el PRD como el PAN sufrirían convulsiones internas que podrían ocasionar que sus dirigentes fuesen removidos, ${ }^{13}$ es decir, la agenda de reformas debía

${ }^{11}$ La intención era firmar el Pacto por México el 28 de noviembre de 2012 para que Enrique Peña Nieto tomara posesión de la presidencia con todos los hilos del poder en la mano. No fue así, el PRD (uno de los tres protagonistas de esa alianza) no logró el consenso.

${ }^{12}$ Para Diego Valadés, si se quería que el Pacto por México adquiriera una dimensión histórica similar a la de los Pactos de la Moncloa, entonces debía aterrizarse en el Congreso de la Unión y convertirse en el Programa de Gobierno de Enrique Peña Nieto. El jurista advirtió que en España los dos pactos de la Moncloa, que se firmaron en la transición española en octubre de 1977, el económico y el político fueron remitidos al Congreso de los diputados y al Senado, y en ambos cuerpos colegiados fueron aprobados. Se aceptaron los principios generales y se crearon las políticas públicas. La aclaración anterior es pertinente, puesto que los firmantes el Pacto por México lo compararon con el histórico pacto español, aunque el resultado de éste con aquel parece impensable. Uno de los aspectos más valiosos, desde su punto de vista, es que el documento recoge la agenda anti-Peña, o la agenda de sus opositores, como es romper con monopolios, la reforma educativa, la apertura del sector de telecomunicaciones, el combate a la corrupción y algunos temas de democracia participativa. Cfr. Núñez, Ernesto, Zermeño, Jésica y Martínez, Martha, "El pacto y sus asegunes", suplemento Enfoque del Periódico Reforma, 9 de diciembre de 2012, p. 4.

${ }^{13}$ Véase, "Nuevo ciclo... iy reformas?", suplemento Enfoque del periódico Reforma, 6 de enero de 2013, p. 12. 
sobrevivir al calendario electoral del 2013, que contemplaba la renovación de los poderes locales en 14 estados, uno de ellos, Baja California, que elegiría nuevo gobernador.

Luego de cumplir dos meses desde su firma el Pacto por México enfrentó una prueba más: el periodo ordinario de sesiones en el Congreso de la Unión, tres meses en los que los partidos tratarían de convertir sus compromisos en reformas de ley. Dos temas sobresalieron como los grandes consensos del consejo rector del pacto: la reforma en telecomunicaciones, que implicaría entre otras cosas abrir la competencia en televisión y en telefonía, y la Ley de Responsabilidad Hacendaria y Deuda Pública, que evitará el endeudamiento excesivo en el que incurren gobernadores y alcaldes. ${ }^{14}$

Es pertinente apuntar que en materia política PAN y PRD advirtieron -al calor de las resoluciones del IFE respecto al financiamiento de la campaña del PRI en el 2012-, que buscarían adelantar para el periodo ordinario de sesiones que iniciaba, el punto 90 del Pacto, programado en la agenda originalmente para el segundo semestre, que estipulaba impulsar una reforma electoral.

Entonces, el acuerdo entró en crisis porque en el estado de Veracruz inició el programa gubernamental denominado "Cruzada Nacional contra el Hambre", en particular por el apoyo que dio el titular del Ejecutivo a la responsable de dicho programa Rosario Robles, debido a las críticas de que era objeto. El PAN denunció la existencia de una red de funcionarios públicos de la Secretaría de Desarrollo Social y del gobierno de ese estado, encargada de utilizar programas sociales para conseguir votos a favor del PRI. Aunque el secretario de Gobernación Miguel Ángel Osorio Chong se reunió el 20 de abril de 2013 con los dirigentes del PAN y del PRD y se comprometió a tomar medidas, los reclamos subieron de tono y en los hechos el pacto entró en una primera crisis, lo que ocasionó, que el Presidente de la República se reuniera con dichos dirigentes. ${ }^{15}$

La crisis fue superada aparentemente después de que los miembros del consejo rector del pacto establecieran tres puntos con el gobierno: a) que no hubiera nuevas iniciativas hasta después de los comicios del 7 de julio; b) el Consejo Rector trabajaría en la legislación secundaria de lo ya acordado y, c) que el punto siguiente fuera instalar una mesa de negociación, para definir una agenda y los límites de una reforma política, pues había surgido una respuesta

${ }^{14}$ Véase, Simonnet, Carole y Núñez, Ernesto, "Pacto a prueba", Suplemento Enfoque del periódico Reforma, 3 de febrero de 2013, p. 10.

${ }^{15}$ Cfr. Núñez, Ernesto, "Pacto por México: un 'estira y afloja', Suplemento Enfoque del periódico Reforma, 19 de mayo de 2013, p. 4 
del Senado que sorprendió a dicho Consejo, en la que los coordinadores parlamentarios del PAN y del PRD dieron a conocer una agenda de 30 puntos para una reforma política profunda y advirtieron que dicha reforma sería negociada, construida y aprobada en la cámara alta y no en el pequeño grupo del pacto. ${ }^{16}$

La reacción al interior del pan fue drástica por lo que el Pacto por México demostró que el apoyo irrestricto al mismo, en un partido fracturado, continuaría impactando con mayor profundidad en su vida interna. Gustavo Madero, presidente del partido, comunicó a Ernesto Cordero el 20 de mayo de 2013, la decisión de removerlo de la coordinación parlamentaria en el Senado.

En este contexto, la cuestión principal de la estrategia del presidente Enrique Peña Nieto era fortalecer su actuación mediante el ejercicio de una presidencia fuerte, reconquistando al Poder Legislativo, volviéndolo de nuevo el antiguo colaborador del Ejecutivo, y de este modo operar todos los cambios que eran necesarios para encauzar la vida económica y social del país.

Pero, con un congreso dividido que no podía garantizar mayorías decisivas y decisorias por la pluralidad a la que había llevado la reforma política, sólo quedaba encontrar el medio de unificar a las diferentes fuerzas políticas mediante objetivos comunes, o en alianzas sólidas que permitieran al gobierno, precisamente, gobernar. El hallazgo se dio con el Pacto por México, del cual nadie tuvo noticia del modo como se acordó (tiempo después se dijo que el promotor original había sido el PRD), hasta que el presidente y los dirigentes de los tres partidos lo anunciaron y lo firmaron. ${ }^{17}$ En este sentido, debe considerarse al Pacto por México como un canal de mediación política frente a la inexistencia de otros canales de mediación, ausentes en esta etapa de la democracia mexicana. ${ }^{18}$

El Poder Legislativo inició con un ritmo intenso de trabajo debido a las iniciativas de ley enviadas por el Poder Ejecutivo, destinadas a modificar debilidades estructurales persistentes en el país, así como otras reformas de carácter legal como fue la nueva legislación que modificó el Juicio de Amparo, figura histórica de protección de las garantías constitucionales que data del siglo XIX, la cual en años recientes había sido explotada por las empresas privadas, para frustrar la acción de las autoridades gubernamentales.

En este proceso, llamó la atención, la cuestión de hasta donde eran ambiciosos los planes del nuevo gobierno, aun cuando la OCDE le había insinuado

\footnotetext{
${ }^{16}$ Ibídem, p. 8.

${ }^{17}$ Córdova, Arnaldo, "Los mitos de Peña Nieto", La Jornada, 15 de septiembre de 2013, p. 13.

${ }^{18}$ Aguilar, Luis F., "La intermediación política", Periódico Reforma, 2 de octubre de 2013, p. 14.
} 
desde el inicio de su mandato, que convenían los cambios deseables, pues las reformas más difíciles de consensuar eran aquellas que buscaban combinarse y generar una sinergia: la reforma fiscal y de energía. Esta última orientada a hacer realidad el enorme potencial de las reservas petroleras y energéticas del país ${ }^{19}$ fundamentalmente porque las ganancias de Pemex que usa de la hacienda pública del Estado habían impedido que dicha empresa invirtiera en la tecnología necesaria para depender menos del ingreso petrolero. En este sentido, el gobierno enfrentaría nuevamente el fantasma de la elevación de impuestos y, probablemente la aplicación del impuesto al valor agregado (IVA) a alimentos y medicinas, medida que mostraba una abrumadora oposición.

\section{El cambio de las relaciones entre el Poder Legislativo y el Poder Ejecutivo, y el control y modificación de la agenda legislativa}

El Pacto por México fue concebido como una mediación convenida entre las dirigencias del PAN, PRI y PRD, cuyo objetivo desde su integración fue el establecimiento de los temas y prioridades de lo que sería una agenda legislativa, que contendría principios, temas y expectativas que se consideraban necesarios, cuya base fue de 95 compromisos que proyectaron cambios y reformas estructurales con orientación de mercado, así como en materia de política electoral y del régimen jurídico; modificaciones que inevitablemente generarían reacciones de diversos grupos y sectores de la sociedad, por lo que la situación exigiría la formación de coaliciones legislativas diversas, debido a la composición de las cámaras, a la fragmentación partidista y a la presión de los grupos de interés.

Se puede afirmar entonces que el Pacto por México, durante el primer año del gobierno del presidente Enrique Peña Nieto, fue una estrategia impulsada por los principales partidos políticos y el gobierno, exitosa para sus fines, aunque frágil por la desconfianza con que participaron los partidos de oposición, pues el gobierno de Peña Nieto tenía varias vulnerabilidades, como fue la crítica al uso de los programas sociales en los procesos electorales que se verificaron en las entidades federativas durante el 2013, prueba de ello es el adendum al pacto firmado por los propios actores seis meses después, en el que reforzaron

${ }^{19}$ Cfr. Economist Intelligence Unit, "México: reformas en marcha", La Jornada, 16 de abril de 2013, p.34. 
obligadamente los principios del pacto original y explicitaron las dudas y razones de su desconfianza. ${ }^{20}$

El Pacto por México fue un instrumento que definió y controló la agenda legislativa pues estableció una dinámica sui generis en ambas cámaras del Congreso, lo que generó sin duda una considerable productividad que, mediante las reformas a la Constitución y a las leyes secundarias, modificaron profundamente el diseño institucional en áreas estratégicas de gobierno y en diversos ámbitos públicos, por ejemplo, al crear y fortalecer organismos reguladores autónomos.

Es importante destacar que en la visión que esbozó el documento firmado, en el que los actores establecieron acuerdos a partir de los cuales se presentarían las iniciativas para el diseño de políticas, se reconoció la creciente influencia de poderes fácticos, los cuales no fueron identificados, pero sí considerados, porque retan la vida institucional del país y se constituyen en un obstáculo para el cumplimiento de las funciones del Estado mexicano.

${ }^{20}$ A pesar de que la mesa de trabajo tripartita que negoció el Pacto por México, integrada por Luis Videgaray y Miguel Ángel Osorio (del PRI-equipo de transición), Gustavo Madero y Santiago Creel (del PAN) y Jesús Zambrano y Jesús Ortega (del PRD), que se comprometieron a alcanzar un gran pacto que definiera las bases de un nuevo acuerdo que abarcara las esferas social, económica y política, y que dicho equipo estableciera nueve reglas de funcionamiento: 1 . Poner todo sobre la mesa desde el principio; 2 . Identificar los puntos coincidentes de una visión de país, así fuese mínimos; 3 . Preservar los puntos de convergencia y tener claras las divergencias (ideológicas o de intereses y de márgenes políticos); 4. Ir siempre de lo sencillo a lo complejo para irnos dando confianza; 5 . Nada negociado hasta que todo esté negociado; 6 . Trabajar con absoluta confianza y discreción; 8. Que las coyunturas y la competencia electoral no nos hagan hacer parar este trabajo de la mesa; y 9 . El objetivo base es recuperar la soberanía del estado democrático y enfrentar a poderes que obstruyen desde distintos ángulos su acción y que buscan conservar su poder en detrimento del interés público, el 7 de mayo de 2013, el Presidente Enrique Peña Nieto y los presidentes de los tres partidos políticos nacionales con mayor representación: César Camacho Quiroz del Revolucionario Institucional, Gustavo Madero Muñoz de Acción Nacional y Jesús Zambrano Grijalva de la Revolución Democrática firmaron un Adéndum al Pacto en el que manifestaron que reafirmaban que era indispensable preservar un entorno político de confianza con base en los siguientes cuatro principios: 1. Sobreponer el interés del país y el de los mexicanos a cualquier interés partidario o individual; 2. Cumplir con la palabra empeñada; 3. Profundizar la transparencia; y 4. Actuar bajo estricto apego a la Constitución y a las leyes de que ella emanan. Lo anterior requirió de dos acuerdos y once compromisos adicionales: Acuerdos para garantizar la limpieza de las elecciones de 2013, así como de modificaciones adicionales a los compromisos originales, adelantando algunos de ellos y estableciendo prioridades en la agenda de dicho pacto. Cfr. Adéndum al Pacto por México, 7 de mayo de 2013. 


\section{El Pacto por México en la "Agenda presidencialista"}

Para entender la relación del Pacto por México en la agenda presidencialista, debemos ampliar el planteamiento esbozado al inicio de nuestro artículo y señalar que el presidencialismo mexicano había detenido su curso desde antes de la alternancia, pues el paso de un sistema de partido hegemónico a uno de pluralismo moderado fue de la mano con la flexibilización, apertura y democratización del viejo sistema autoritario. Con ello, sin embargo -afirma Ricardo Espinoza Toledo-, dio inicio el reto de lograr la eficacia del gobierno en el marco del pluralismo político, en razón de que la transición democrática no se hizo acompañar de la transformación del entramado institucional. ${ }^{21}$

La realidad del sistema político mexicano antes del Pacto por México era la de un Congreso plural sin mayorías predefinidas, un necesario contrapeso al poder Ejecutivo que, sin embargo, dificulta el desempeño del presidente de la República. Ante este escenario se elaboraron diversas propuestas de solución: "la dominante es aquella que planteó fortalecer al poder Ejecutivo a través de una agenda que permitiera instaurar la supremacía presidencial, le otorgara al Presidente una mayoría legislativa por encima de los electores o lo reposicionara a través de un gobierno de coalición". ${ }^{22}$

Los diagnósticos a los que se les consideró como alternativas relevantes son los siguientes: a) el de la transición estancada y, b) el de la reivindicación del pluralismo como fundamento de un sistema parlamentario. A juzgar por una u otra opción, lo que hizo falta era un diseño institucional para el pluralismo que los gobiernos surgidos del PAN no impulsaron.

En este sentido, en un contexto de gobierno sin mayoría que, como señalamos, data de 1997, en el que ciertamente no se ha presentado una parálisis en el Congreso, o ingobernabilidad en el mismo, con el regreso del PRI al poder se presentaba un escenario de diversas combinaciones, en función de las tendencias cooperativas que habían modulado el patrón de competencia entre los partidos para integrar la agenda del Ejecutivo y su partido, debido en buena medida a la existencia de gobiernos sin mayoría, entendidos a partir de la circunstancia en que ningún partido podía modificar la Constitución Política sin el apoyo de otros, tanto en el Congreso general como en los congresos locales. ${ }^{23}$

\footnotetext{
${ }^{21}$ Espinoza Toledo, Ricardo, op. cit., p. 33-34.

${ }^{22}$ Ibídem, p. 34.

${ }^{23}$ Véase, Casar, María Amparo y Marván, Ignacio, Gobernar sin mayoría, México 1867-1997, México, CIDE-Taurus, 2002, p. 9.
} 
Para analizar la relación del presidencialismo con el pluralismo en México es pertinente enmarcar el tema en la perspectiva teórica del presidencialismo y la democracia en América Latina, en particular si nos proponemos conocer los factores que afectan marcadamente el funcionamiento y el desempeño de las democracias presidenciales.

En este sentido, el estudio del presidencialismo cobra relevancia teórica en el contexto latinoamericano para la política comparada, en particular para identificar las características constitucionales del titular de Ejecutivo que, como en otros países, se debate entre la concentración y la dispersión del ejercicio del poder.

En este debate autores como Scott Mainwaring y Matthew Soberg Shugart han estudiado el desempeño que históricamente ha tenido el presidencialismo, las ventajas y desventajas de este tipo de régimen y que, por medio de una atención cuidadosa al diseño constitucional e institucional, sus ventajas pueden ser maximizadas para reducir sus desventajas. Por ello, ambos autores se propusieron identificar variantes dentro del tipo de régimen presidencialista, con el fin de no tratar a todos los regímenes presidencialistas como si fueran iguales y destacar una característica constitucional básica: los poderes legislativos reconocidos al presidente. ${ }^{24}$

Otro de los estudios que se refieren al presidencialismo que coexiste con las formas pluralistas frente a las formas mayoritarias y plebiscitarias, que analiza las prácticas de compromiso y las experiencias de coalición, es el de Jorge Lanzaro, que afirma que éstas no son exclusivas del parlamentarismo, pues se producen también en los regímenes presidenciales, dando lugar a un "presidencialismo de coalición". 25

En México, ante el posible desequilibrio en la relación de poderes frente a la búsqueda de un balance institucional, se modificó después de un largo debate su "diseño institucional" como producto de la reforma político-electoral aprobada en los cambios constitucionales del 13 de diciembre de 2013. Su objetivo fue beneficiar cuando menos dos aspectos cruciales para la gobernabilidad democrática en el país: el régimen de partidos y la estabilidad institucional entre los poderes de la Unión.

Estos cambios forman parte de la "agenda presidencialista" a la que nos referimos, cuya ruta se encuentra en la "conveniencia de crear mayorías presidenciales, abrir el régimen de partidos y fortalecer al poder Ejecutivo". ${ }^{26}$

\footnotetext{
${ }^{24}$ Mainwaring, Scott y Shugart, Mattew Soberg (comps.), op. cit., pp. 62-63.

${ }^{25}$ Lanzaro, Jorge (comp.), Tipos de presidencialismo y coaliciones políticas en América Latina, Buenos Aires, Consejo Latinoamericano de Ciencias Sociales, 2010, p. 15.

${ }^{26}$ Espinoza Toledo, Ricardo, op. cit., p. 40.
} 
Los mecanismos establecidos para lograrlo se han desarrollado de la siguiente manera:

El sistema presidencial mexicano por décadas no se había renovado y existían señalamientos de que sus defectos institucionales se podrían exacerbar. En las elecciones de 2012 las condiciones de gobernabilidad del país corrieron nuevamente el riesgo de estar muy comprometidas, en una contienda en la que los partidos políticos se aprestaron a participar en ella, llamando a la unidad como estrategia electoral, mas no como objetivo de gobierno; es decir, más como instrumento para vencer al adversario que para compartir con él, el poder.

Ante la perspectiva de que la ciudadanía decidiera no otorgar la mayoría del Congreso a un solo partido, algunos especialistas destacaron frente a esta situación tres grandes opciones: a) suprimir la representación proporcional e integrar al Congreso mediante elecciones mayoritarias, incluyendo la segunda vuelta; b) adoptar la llamada "cláusula de gobernabilidad" o, c) disponer de mecanismos que, sobre la base de un proyecto de gobierno compartido, permitieran integrar una mayoría compuesta por miembros de diferentes partidos. ${ }^{27}$

Parte de la "agenda presidencialista" fue aprobada en pleno proceso electoral del 2012, cuyo origen fue una iniciativa del presidente Felipe Calderón en diciembre de 2009, discutida y ampliada por el PRI, el PRD y el PAN en el Senado el 27 de abril de $2011,{ }^{28}$ la cual tuvo un accidentado camino y, tras haber experimentado sucesivas transformaciones y que el PRI la consideró "muerta" en por lo menos dos ocasiones, el proyecto de reforma finalmente logró sumar los votos suficientes en ambas cámaras (fue aprobada por la Cámara de Diputados el 19 de abril de 2012) para la incorporación a la Constitución, entre otros cambios importantes el de las Candidaturas Independientes, la Iniciativa Popular, y que el día de la apertura de cada periodo ordinario de sesiones, el Presidente de la República pudiera presentar hasta dos iniciativas para trámite preferente que, una vez recibidas por la cámara de origen, ésta debiera pronunciarse en un plazo de 30 días naturales, con lo que el Ejecutivo se fortalecería, coadyuvaría a evitar la inacción legislativa, modificaría las prioridades de la agenda y replantearía los esquemas de negociación entre el Ejecutivo y el Congreso. ${ }^{29}$

\footnotetext{
${ }^{27}$ Véase, Valadés, Diego, “¿Hacia dónde vamos?”, Suplemento Enfoque del Periódico Reforma, 11 de septiembre de 2011, p.2.

${ }^{28}$ Cfr. Zamitiz Gamboa, Héctor, "Encuentro y superposición de agendas: la reforma política aprobada por el Senado en el 2011", Estudios Políticos, núm. 25, enero-abril, México, 2012, pp. 55-88.

${ }^{29}$ Cfr. Zamitiz Gamboa, Héctor, "La reforma política del 2012: 'Ingeniería constitucional' de la segunda alternancia en la Presidencia de la República”, en Béjar Algazi, Luisa (coord.), ¿Quién, cómo y que se legisla en México? México, UnAm, 2013, p. 187.
} 
Conviene recordar que en el proceso electoral de 2012 el candidato del PRI, Enrique Peña Nieto, puso en juego dos de las alternativas de solución: la "cláusula de gobernabilidad" y la proporcionalidad, al proponer la supresión de 100 diputados plurinominales, propuesta que también fue avalada por su partido, para ser considerada en una Consulta Popular que no se realizó debido a que la Suprema Corte de Justicia de la Nación consideró las propuestas de los partidos como no procedentes en el 2014.

En este contexto, durante la última década observamos una opinión cada vez más amplia que se forjó, tanto en la academia como en el periodismo y en la política, para introducir la figura del "gobierno de coalición", no como producto de un acuerdo político, sino con pleno respaldo jurídico.

Frente a esta situación el 14 de septiembre del 2011 el senador Manlio Fabio Beltrones presentó una iniciativa apoyada por los coordinadores del PRD y del PAN, para hacer visible y plasmar en la Constitución la posibilidad de construir un gobierno de coalición. La idea se sustentó en el supuesto de que un presidente sin mayoría en el Congreso, pudiera optar entre gobernar en solitario o acogerse a la figura de gobierno de coalición legalmente establecida. En este sentido, la propuesta dotaría al Ejecutivo de la capacidad de elección sobre los gobiernos de coalición hasta por tres años, ya fuera para fortalecer institucionalmente su mandato o para construir una mayoría gobernante.

Esta propuesta, a la que también se le llamó "la tercera vía", sustancialmente proponía lo siguiente: "el presidente minoritario se hará de un partido aliado con el cual formaría una mayoría gobernante. Para ello, estaría obligado a presentar ante el Congreso la solicitud formal de constituirse en gobierno de coalición, bajo tres premisas: la presentación de un 'Plan de gobierno compartido' por los miembros de la coalición; una 'Agenda legislativa común' y un 'Gabinete acordado', los cuales deberían ser ratificados por la mayoría del Congreso". ${ }^{30}$ Dicho gobierno de coalición sería negociado previamente a la construcción de una plataforma mayoritaria en el Congreso; para esto sería necesario acordar las políticas y la conformación del gabinete, los cuales requerirán un determinado número de votos necesarios para ser ratificados. El presidente podrá, en todo momento, nombrar y remover a su gabinete, en caso de que la coalición dejara de funcionar, superando así cualquier contingencia de naturaleza política en caso de abandono de la coalición, o bien si obtuviera una mayoría legislativa de su partido después de una elección federal intermedia. En suma, la pro-

${ }^{30}$ Ver, Casar, María Amparo "Gobierno de coalición: la tercera vía", periódico Reforma, 15 de septiembre de 2011, p. 9. 
puesta dotaba tanto al Ejecutivo como al Legislativo de una nueva capacidad de conducción y dispondría de herramientas que facilitaran e incentivaran el trabajo conjunto. ${ }^{31}$

Por lo tanto, era crucial que los partidos y sus potenciales candidatos estuvieran conscientes de que no bastaría vencer en las elecciones presidenciales del $1^{\circ}$ de julio de 2012, pues de no modificarse el diseño institucional en el sentido antes propuesto, quien obtuviera el triunfo se enfrentaría inevitablemente al desafío de gobernar, frente al fantasma de la ingobernabilidad.

Entonces el cambio efectuado se contempló en el decreto de reforma políticoelectoral publicado por el Diario Oficial de la Federación el 10 de febrero de 2014, en el artículo 89, fracción XVII, en el que se establece que el presidente de la República (podrá) "en cualquier momento optar por un gobierno de coalición con uno o varios de los partidos políticos representados en el Congreso de la Unión. El gobierno de coalición se regulará por el convenio y el programa respectivos, los cuales deberán ser aprobados por mayoría de los miembros presentes de la Cámara de Senadores. El convenio establecerá las causas de la disolución del gobierno de coalición". ${ }^{32}$

Conviene señalar, observando hacia el futuro, que la propuesta de gobierno de coalición no será suficiente, por lo que la ingeniería constitucional, en particular la normatividad que rige la división de poderes, de no encontrar otra fórmula, continuará insistiendo en la "agenda presidencialista"; es decir, en revisar la "cláusula de gobernabilidad" para la integración de las cámaras, con el fin de favorecer la formación de mayorías que le permitan al Ejecutivo ejercer sus facultades con gobernabilidad. En esta ruta, observaremos la reiteración de la iniciativa de pasar de 200 a 100 diputados por el principio de representación proporcional, el cual se sigue considerando como un recurso indispensable, para modificar la lógica de la apertura del sistema político a partir de que se estableciera esta medida. ${ }^{33}$

Con los cambios establecidos en el diseño institucional un tema que era obligado observar enmarcado en la firma y cumplimiento del Pacto por México, es el que se refiere al propio proceso político-legislativo, en lo que respecta a la evaluación del papel del Ejecutivo, que en esta ocasión no hizo uso de las

${ }^{31}$ Consúltese, "Gobiernos de coalición, instrumento para resolver parálisis institucional: Beltrones", La Jornada, 19 de septiembre de 2011, p. 20.

${ }^{32}$ Cfr. LXII Legislatura, Gaceta Parlamentaria, año. XVII, núm. 3964-VII, 18 de febrero de 2014, p. 12. (El paréntesis es nuestro).

${ }^{33}$ Véase, Murat, José, "Reforma del Estado inconclusa”, La Jornada, 9 de noviembre de 2015, p. 18. 
dos iniciativas preferentes contempladas en el artículo 35, fracción II de la Constitución Federal, y del Congreso en la actividad legislativa, que es ejercida por ambos pero que responde a variables políticas relacionadas con el diseño institucional actual y con el sistema de partidos vigente. ${ }^{34}$

\section{Conclusiones}

La firma del Pacto por México fue vista como una oportunidad para establecer una agenda amplia de discusión política que, más allá de los buenos propósitos contenidos en los 95 puntos, enfrentó como primera dificultad hacer compatibles visiones programáticas distintas e incluso contrapuestas, con miras al cumplimiento de cada uno de los propósitos.

Aunque el mecanismo no fue más incluyente como muchos deseaban, el documento definió un contenido de gran importancia. Uno de los aspectos centrales que fue motivo de cuestionamiento fue la ausencia de un consenso respecto de los procedimientos que dicho pacto debería seguir, por lo menos para evitar que fuera un mecanismo de acuerdo político endeble y por lo tanto no perdurable.

Cualquier pretexto podía servir para que afloraran las pugnas y las diferencias y los actores pudieran levantarse de la mesa. Prueba de esto fue el caso del Adendum a dicho Pacto que fue firmado por los tres partidos y el gobierno seis meses después de su puesta en marcha, por lo que es pertinente valorar el contenido del mismo, pues denuncia prácticas negativas recurrentes de los partidos políticos y el gobierno en nuestro país.

En este sentido, se puede afirmar que la mayor fuerza del espíritu que animó al pacto fue su mayor debilidad; es decir, la intención del Presidente Enrique Peña Nieto de que todas las fuerzas políticas lo asumieran, no correspondía a la dinámica de un proceso democrático, por el contrario dio la impresión de que nos encontramos en un régimen autoritario que pretendía la eliminación de la divergencia.

Lo anterior suponía un riesgo frente a las diferencias existentes entre los partidos políticos, no sólo porque cada uno de ellos representa una visión política y social diferente, sino porque éstos representan a grupos de interés y, desde un principio, la agenda tocaba intereses diversos.

${ }^{34}$ García Montero, Mercedes, Presidentes y parlamentos: ¿quién controla la actividad legislativa en América Latina?, Madrid, Centro de Investigaciones Sociológicas, Colección Monografías, núm. 269, 2009, p. XVI. 
En este sentido, aunque el pacto comprometía al Presidente con los partidos políticos firmantes, los dirigentes del PAN y del PRD corrían un riesgo al pactar con el gobierno pues sujetaron con este hecho su papel opositor. Si su compromiso tenía éxito se cubrirían de gloria, pero si fracasaba difícilmente evitarían el reclamo de grupos o corrientes opositoras que los señalarían como comparsas del poder.

Paradójicamente, la "abdicación" de las responsabilidades opositoras en nombre del consenso, fortalecía también su carácter de oposición, lo cual dependía de la forma en que jugaran estratégicamente sus cartas contenidas en la alianza, o bien amenazaran con salirse de la misma, o que ambas jugaran juntas o por separado.

El análisis del proceso legislativo del Pacto por México nos demuestra que durante la negociación de las reformas, se pudo observar una suplantación de la discusión parlamentaria, pues su diseño fue previamente acordado entre el gobierno y los representantes de los tres principales partidos (en este sentido consideramos importante profundizar en los documentos formales del Consejo Rector del pacto), por tanto, los dictámenes finales y las reservas en el pleno, así como el limitado debate puede calificarse de un mero formalismo.

La preeminencia del poder Ejecutivo frente al Legislativo fue innegable. Por su parte el Legislativo, en determinados momentos exhibió su negación a potenciar su capacidad, pues parte de su debilidad se encuentra, entre otros aspectos, en la opacidad con la que ejerce los recursos públicos, lo que hace posible que el Ejecutivo termine cooptando a los opositores o bien los neutralice.

\section{Fuentes}

"Gobiernos de coalición, instrumento para resolver parálisis institucional: Beltrones", La Jornada, 19 de septiembre de 2011.

"Nuevo ciclo... ¿y reformas?", suplemento Enfoque del periódico Reforma, 6 de enero de 2013.

Adéndum al Pacto por México, 7 de mayo de 2013.

Aguayo, Sergio, "Cambiar", La Jornada, 4 de septiembre de 2013.

Aguilar, Luis F., "La intermediación política", Periódico Reforma, 2 de octubre de 2013. Casar, María Amparo "Gobierno de coalición: la tercera vía", periódico Reforma, 15 de septiembre de 2011.

Casar, María Amparo y Marván, Ignacio, Gobernar sin mayoría, México 1867-1997, México, CIDE-Taurus, 2002. 
Castañeda, Jorge, "Encuestas a un año", Periódico Reforma, 5 de diciembre de 2013.

Córdova, Arnaldo, "Los mitos de Peña Nieto", La Jornada, 15 de septiembre de 2013.

Delgado, René, "Cambio o resistencia", Periódico Reforma, 2 de noviembre de 2013.

Delgado, René, Periódico Reforma, 20 de julio de 2013.

Economist Intelligence Unit, "México: reformas en marcha", La Jornada, 16 de abril de 2013.

Espinoza Toledo, Ricardo, "El estancamiento del presidencialismo mexicano: la relación entre los poderes Ejecutivo y Legislativo", en Escamilla Cadena, Alberto y Becerra Chávez, Pablo Javier (coords.), El presidencialismo mexicano durante los gobiernos de la alternancia, México, UAM, Iztapalapa-Miguel Ángel Porrúa, 2013.

García Montero, Mercedes, Presidentes y parlamentos: ¿quién controla la actividad legislativa en América Latina?, Madrid, Centro de Investigaciones Sociológicas, Colección Monografías, núm. 269, 2009.

Lanzaro, Jorge (comp.), Tipos de presidencialismo y coaliciones políticas en América Latina, Buenos Aires, Consejo Latinoamericano de Ciencias Sociales, 2010.

LXII Legislatura, Gaceta Parlamentaria, año. XVII, núm. 3964-VII, 18 de febrero de 2014.

Mainwaring, Scott y Shugart, Mattew Soberg (comps.), Presidencialismo y democracia en América Latina, Buenos Aires, Paidós, 2012.

Martínez, Martha, "Nuevo gobierno, mismo diseño", Suplemento Enfoque del Periódico Reforma, 2 de diciembre de 2012.

Murat, José, "Reforma del Estado inconclusa", La Jornada, 9 de noviembre de 2015.

Núñez, Ernesto, "Pacto por México: un 'estira y afloja', Suplemento Enfoque del periódico Reforma, 19 de mayo de 2013.

Núñez, Ernesto, Zermeño, Jésica y Martínez, Martha, "El pacto y sus asegunes", suplemento Enfoque del Periódico Reforma, 9 de diciembre de 2012.

Simonnet, Carole y Núñez, Ernesto, "Pacto a prueba", Suplemento Enfoque del periódico Reforma, 3 de febrero de 2013.

Valadés, Diego, “¿Hacia dónde vamos?”, Suplemento Enfoque del Periódico Reforma, 11 de septiembre de 2011.

Voz y Voto, Política y Elecciones, "Enrique Peña Nieto 5 ejes, 13 decisiones. Mensaje a la nación $1^{\circ}$ de diciembre de 2012", núm. 239.

Zamitiz Gamboa, Héctor, "Encuentro y superposición de agendas: la reforma política aprobada por el Senado en el 2011", Estudios Políticos, núm. 25, enero-abril, México, 2012.

Zamitiz Gamboa, Héctor, "La reforma política del 2012: 'Ingeniería constitucional' de la segunda alternancia en la Presidencia de la República", en Béjar Algazi, Luisa (coord.), ¿Quién, cómo y que se legisla en México? México, UnAM, 2013. 


\section{REFORMA POLÍTICA, PARIDAD DE GÉNERO EN \\ EL CONGRESO MEXICANO Y LOS NUEVOS PARÁMETROS \\ DE LA RELACIÓN EJECUTIVO-LEGISLATIVO}

\section{Gloria Luz Alejandre Ramírez}

\section{La apertura}

L

a etapa posterior a la alternancia política en México registrada hacia julio del año 2000, logra el cambio político indispensable para favorecer los mecanismos del modelo institucional plasmado en la Constitución y, con ello, hacer patente el denominado salto de un régimen autoritario a una democracia para modificar las formas tradicionales de ejercicio y transmisión del poder del México del Siglo XXI.

Sin duda, dentro de las teorías que nos hablan de cambio político tenemos un planteamiento central,

De acuerdo con Guillermo O'Donnell y Philippe Schmitter... La liberalización es el 'proceso por el cual se hacen efectivos ciertos derechos que protegen tanto a individuos como a grupos sociales de los actos arbitrarios e ilegales cometidos por el Estado o por terceras personas... La democratización, por otro lado, consiste en la aplicación de 'reglas y procedimientos de ciudadanía'; es decir democratizar consiste en hacer efectivos derechos y obligaciones políticas... ${ }^{1}$

Sobre la condición vinculada a la liberalización política, se puede decir que atiende a la apertura y a la competencia dentro de un mercado electoral de

${ }^{1}$ O'Donnell, Guillermo y Schmitter, Philipe C., Transitions from Authoritarian Rule. Tentative Conclusions about Uncertain Democracies, The Johns Hopkins University Press, Baltimore, 1986, cit. Por Meyer-Serra, Carlos Elizondo y Nacif Hernández, Benito, "La lógica del cambio político en México" en Meyer-Serra, Carlos Elizondo y Nacif Hernández, Benito (comps.), Lecturas sobre el cambio político en México, México, CIDE-FCE, 2002, p. 11. 
inicio, por otra parte, la condición de democratización se instala una vez que se promueven y establecen las reglas del nuevo juego político basado en un orden institucional vinculado a un gobierno plenamente democrático y ligado a la lógica de la división de poderes y equilibrio entre los mismos.

Una vez consumado el desgaste al interior del partido hegemónico, propiamente en 1994, la consecuencia inmediata se centró en la reconformación de los mecanismos institucionales enunciados en la Constitución Política para atender los procesos electorales próximos, tanto federales como locales, con una especial atención en la elección presidencial de julio de 2000. Sin duda, los elementos de naturaleza política y económica estuvieron presentes en el cambio de régimen y alternancia. Con ello hacia 1997, con las elecciones intermedias, el Revolucionario Institucional pierde su mayoría en el Congreso y la visión hacia el 2000 cobró fuerza en la voluntad de la oposición panista, que, sin menoscabo del candidato, Vicente Fox, vislumbraba una amplia posibilidad para colocarlo en la Presidencia, posibilidad que aprovechó y consumó al ganar las elecciones de julio de aquel año.

Junto con el cambio de régimen, un nuevo partido en el Poder y un Congreso dividido, la apertura política democrática también provocó discusiones y adecuaciones significativas a nivel normativo para favorecer uno de los aspectos medulares que acompañarían al cambio político en México y que, a su vez, derivarían en reformas constitucionales en los años inmediatos, asociadas a la continua construcción y conformación de legislaciones para favorecer los derechos a las mujeres, librarlas de la violencia en el espacio privado y público y promover mejores escenarios de participación política en condiciones de igualdad. Este aspecto, por sí mismo, ocupa un tema importante, la promoción paritaria entre mujeres y hombres para ocupar puestos de elección popular en el Congreso mexicano y con ello instalar condiciones de igualad, por lo menos en materia político electoral.

El camino no ha sido fácil y en este capítulo se exponen los elementos propios de esta condición democrática que ahora caracteriza al Estado mexicano del siglo XXI y a sus instituciones políticas proclives a la consolidación de la paridad de género en materia electoral para dar cuenta de las nuevas relaciones de poder y de composición política al interior de Poder Legislativo en ambas Cámaras. El Estado mexicano de manera paulatina ha asumido como razón per se la búsqueda de esta normatividad para empatar con dictados de naturaleza internacional, ligados a los derechos que merecen todas las mujeres, como derecho humano, y su incorporación en leyes, incluyendo a la propia Constitución Política Mexicana como norma fundamental, así como en códigos 
y reglamentos. En particular se destaca cómo se llevaron a cabo las reformas políticas que dieron cuenta de estos cambios. Los adelantos en materia de paridad de género en los procesos políticos electorales han sido claros e incluso contundentes. Actualmente, México se suma a los pocos países en la región de Latinoamérica, Bolivia, Ecuador y Nicaragua, que ya cuentan con paridad 50/50 para todas sus elecciones federales, estatales y municipales, para impulsar condiciones de igualdad de género entre mujeres y hombres respectivamente, tanto en el sistema electoral, como en el propio sistema de partidos, ya que con ello logra establecer acciones afirmativas en pos de las mujeres que desean arribar a cargos de elección popular. Este punto, además de alentador, consolida legitimidad para el actual gobierno. Sin duda, alcanzar la paridad favorece aspectos sensibles a esta democracia mexicana, aún en ciernes.

\section{El Estado mexicano y su posición frente a las mujeres en la conformación del nuevo Sistema Político del siglo XXI}

Nuestro actual Sistema Político Mexicano dista en buena medida de la composición institucional que tenía hacia finales de los años ochenta, alusivos a la ruptura interna en el entonces Revolucionario Institucional, como partido hegemónico, ya no digamos los años veinte y posteriores que conformaron el antiguo régimen propio del siglo XX. En este siglo XXI, el Sistema Político Mexicano se precia de contar con mejores instituciones y con un adecuado equilibrio de poderes funcional, así como con un sistema electoral y un sistema de partidos que, también paulatinamente, han adquirido mayor madurez de frente a procesos políticos electorales más competidos y complejos, aunque una garantía plena de la calidad de la democracia, en todos los rubros, aún está por verse.

Así pues, es en este siglo que las condiciones de las mujeres en el Sistema Político Mexicano arriba a horizontes más favorecedores a partir de la alternancia, por lo que toca al sistema normativo tenemos diversas iniciativas gubernamentales que se perfilaron en función de mejoras sustanciales. Los cambios en la normatividad a nivel nacional, se hicieron manifiestas de tal suerte que en el nuevo milenio se han promulgado: la Ley Federal para Prevenir y Eliminar la Discriminación, emitida el 11 de junio de 2003; la Ley General para la Igualdad entre Mujeres y Hombres, publicada el 2 de agosto de 2006; la Ley General de Acceso de las Mujeres a una Vida Libre de Violencia, que aparece en el Diario Oficial de la Federación el primero de febrero de 2007. En este contexto 
normativo podemos hablar de que el elemento de concreción de ciudadanía y respeto hacia las mujeres se asume con otra connotación.

Los elementos legales adquieren forma y aplicación en las instituciones públicas destinadas para cumplir y hacer válidas las disposiciones normativas y otorgarles oportunidades plenas a las mujeres mexicanas del siglo XXI. Si hacemos un breve recuento, el orden estatal dispuso desde su Plan Nacional de Desarrollo del gobierno de la alternancia, la conformación administrativa para hacer plausible y operativo a nivel gubernamental las acciones y recomendaciones a favor de las mujeres a través del Instituto Nacional de las Mujeres (INMUJERES), surgido en 2001. El Plan de gobierno del entonces presidente Vicente Fox, colocó en su punto 5.3.2. Equidad e igualdad. Objetivo rector 2: acrecentar la equidad y la igualdad de oportunidades, el siguiente enunciado: "Incrementar la equidad e igualdad de oportunidades implica utilizar criterios que reconozcan las diferencias y las desigualdades sociales para diseñar estrategias de política social dirigidas a ampliar y ofrecer igualdad de oportunidades a todos los hombres y mujeres de la población mexicana". ${ }^{2}$ Que se materializó con el INMUJERES y con las leyes propias del sexenio referido.

En continuidad con las políticas de equidad e igualdad logradas, el Plan Nacional de Desarrollo de 2007-2012 del expresidente Felipe Calderón, estableció en su Eje 3. Igualdad de oportunidades; Punto 3.5 Igualdad entre mujeres y hombres, lo siguiente:

...el Gobierno de la República se compromete a promover acciones para fomentar una vida sin violencia ni discriminación, así como una auténtica cultura de la igualdad. Este último tipo de acciones se llevan a cabo para promover la igualdad que actualmente no existe en México. Asimismo, el gobierno participará activamente en la implantación de políticas públicas encaminadas a defender la integridad, la dignidad y los derechos de todas las mexicanas. Es bajo esta inteligencia que se incorpora la perspectiva de género de manera transversal en cada uno de los ejes que conforman el presente plan. ${ }^{3}$

Sumado a este punto el Objetivo 16 del Plan determinó: "Eliminar cualquier discriminación por motivos de género y garantizar la igualdad de oportunidades

\footnotetext{
${ }^{2}$ Gobierno de los Estados Unidos Mexicanos, Plan Nacional de Desarrollo 2001-2006, México, 2001, pp. 83-84, Disponible en: <http://bibliotecadigital.conevyt.org.mx/colecciones/conevyt/plan_desarrollo.pdf>

${ }^{3}$ Gobierno de los Estados Unidos Mexicanos, Plan Nacional de Desarrollo 2007-2012, México, 2007, pp. 210-211. Disponible: <http://pnd.calderon.presidencia.gob.mx/pdf/PND_2007-2012.pdf>
} 
para que las mujeres y los hombres alcancen su pleno desarrollo y ejerzan sus derechos por igual". ${ }^{4}$ Las propuestas y estrategias de atención a los objetivos del Plan 2007-2012 se perfilaron a través del Programa Nacional para la Igualdad entre Mujeres y Hombres 2009-2012 (PROIGUALDAD, 2009), emitido en julio de 2008 como política de Estado en la materia y encargado a INMUJERES.

Se perfilaron siete objetivos estratégicos medulares, a saber:

1. "Institucionalizar una política transversal con perspectiva de género en la Administración Pública Federal y construir los mecanismos para contribuir a su adopción en los poderes de la unión, en los órdenes de gobierno y en el sector privado.

2. Garantizar la igualdad jurídica, los derechos humanos de las mujeres y la no discriminación, en el marco del estado de derecho.

3. Garantizar el acceso de las mujeres a la justicia, la seguridad y la protección civil.

4. Garantizar el acceso de las mujeres a una vida libre de violencia.

5. Fortalecer las capacidades de las mujeres para ampliar sus oportunidades y reducir la desigualdad de género.

6. Potenciar la agencia económica de las mujeres a favor de mayores oportunidades para su bienestar y desarrollo.

7. Impulsar el empoderamiento de las mujeres, su participación y representación en espacios de toma de decisión en el Estado y consolidar la cultura democrática." 5

A nivel internacional, los Objetivos del Milenio y más allá de 2015 de la ONU, se han convertido en los referentes más significativo para darle cumplimiento y obliga a los Estados miembros, entre ellos México, a aplicarse a fondo en los cometidos que las metas marcan.

Como datos de alcance que dan cuenta de cierto avance en materia de género, los mismos Objetivos de Desarrollo del Milenio; en su Informe 2013, emitido, señalaba que:

\footnotetext{
${ }^{4}$ Idem.

${ }^{5}$ Instituto Nacional de las Mujeres, Programa Nacional para la Igualdad entre Mujeres y Hombres 20082012, México, 2008. Disponible en: <http://www.hacienda.gob.mx/LASHCP/equidad/marco_legal/100919. $\mathrm{pdf}>$.
} 
- Se ha avanzado de forma constante en el logro del acceso en pie de igualdad de las niñas y los niños a la enseñanza, pero siguen existiendo disparidades entre las regiones y los niveles educativos.

- A escala mundial, la proporción de mujeres empleadas fuera del sector agrícola ascendió al 40 por ciento, pero aumentó solo hasta el 20 por ciento en Asia Meridional, Asia Occidental y África Septentrional.

- La proporción mundial de mujeres parlamentarias sigue aumentando poco a poco y alcanzó el 20 por ciento en 2012 , lo cual dista mucho de la paridad entre los géneros; no obstante durante 2012 se observó un aumento de un punto porcentual. ${ }^{6}$

Para el Informe 2015, en su Objetivo 3: Promover la igualdad de género y el empoderamiento de la mujer, la propia ONU reporta que: "En el curso de los últimos 20 años las mujeres han ganado terreno en la representación parlamentaria en casi el 90 por ciento de los 174 países para los que se dispone de datos. La proporción promedio de mujeres en el parlamento casi se ha duplicado en el mismo período; sin embargo, todavía solo uno de cada cinco miembros es mujer". ${ }^{7}$ De este modo el siglo XXI nos ha marcado con el compromiso de dar cumplimiento a las leyes internacionales en materia de derechos humanos que regulan y promueven la igualdad entre hombres y mujeres en el entorno global ligadas estrechamente a las determinaciones marcadas por los organismos internacionales para que esto así sea en el orden nacional.

Sin duda la agenda está en el Plan Nacional de Desarrollo 2013-2018 que, de manera amplia, coloca su rubro III. México Incluyente, como eje rector en la concreción de condiciones de igualdad y establece como Plan de acción: integrar una sociedad con equidad, cohesión social e igualdad de oportunidades. ${ }^{8}$ Dentro de sus estrategias transversales la Perspectiva de Género ocupa y cruza a todo el Plan Nacional de Desarrollo como compromiso de Estado.

En este sentido se publicó el 20 de agosto de 2013 en el Diario Oficial de la Federación, el actual Programa Nacional para la Igualdad de Oportunidades

${ }^{6}$ Organización de las Naciones Unidas, Objetivos para el Milenio. Informe de 2013. Disponible en: <http:// www.un.org/es/millenniumgoals/pdf/mdg-report-2013-spanish.pdfs.

${ }^{7}$ Organización de las Naciones Unidas, Objetivos para el Milenio. Informe de 2015. Disponible en: <http:// www.un.org/es/millenniumgoals/pdf/2015/mdg-report-2015_spanish.pdf>.

${ }^{8}$ Gobierno de la República, Plan Nacional de Desarrollo 2013-2018, México, 2013. Disponible en: <http:// pnd.gob.mx/wp-content/uploads/2013/05/PND.pdf>. 
y no Discriminación contra las Mujeres 2013-2018. ${ }^{9}$ Propiamente el Programa define la agenda de gobierno en materia de género para atenderlo y plasma los Objetivos destinados a darle curso y cumplimiento, entre ellos el Objetivo transversal 6: Incorporar las politicas de igualdad de género en los tres órdenes de gobierno y fortalecer su institucionalización en la cultura organizacional y su Estrategia 6.2 Promover la igualdad de género en las oportunidades y resultados de la democracia y el desarrollo político.

La Ley General para la Igualdad entre Mujeres y Hombres, ${ }^{10}$ en su Capítulo Tercero; Apartado de la Participación y Representación Política Equilibrada de las Mujeres y los Hombres, establece dos artículos sustantivos en la materia:

Artículo 35.- La Política Nacional propondrá los mecanismos de operación adecuados para la participación equitativa entre mujeres y hombres en la toma de decisiones políticas y socioeconómicas.

Artículo 36.- Para los efectos de lo previsto en el artículo anterior, las autoridades correspondientes desarrollarán las siguientes acciones:

I. Favorecer el trabajo parlamentario con la perspectiva de género;

II. Garantizar que la educación en todos sus niveles se realice en el marco de la igualdad entre mujeres y hombres y se cree conciencia de la necesidad de eliminar toda forma de discriminación;

III. Evaluar por medio del área competente de la Comisión Nacional de los Derechos Humanos, la participación equilibrada entre mujeres y hombres en los cargos de elección popular;

IV. Promover participación y representación equilibrada entre mujeres y hombres dentro de las estructuras de los partidos políticos;

v. Fomentar la participación equitativa de mujeres y hombres en altos cargos públicos;

VII. Desarrollar y actualizar estadísticas desagregadas por sexo, sobre puestos decisorios y cargos directivos en los sectores público, privado y de la sociedad civil, y

${ }^{9}$ Diario Oficial de la Federación, Decreto por el que se aprueba el Programa Nacional para la Igualdad de Oportunidades y no Discriminación contra las Mujeres 2013-2018, México, 30 de agosto de 2013. Disponible en: <http://www.dof.gob.mx/nota_detalle.php?codigo=5312417\&fecha=30/08/2013>.

${ }^{10}$ Diario Oficial de la Federación, Ley General para la Igualdad entre Mujeres y Hombres, México, 2 de agosto de 2006. Disponible en: <http://www.diputados.gob.mx/LeyesBiblio/pdf/LGIMH_040615.pdf>. 
VII. Fomentar la participación equilibrada y sin discriminación de mujeres y hombres en los procesos de selección, contratación y ascensos en el servicio civil de carrera de los poderes Ejecutivo, Legislativo y Judicial. ${ }^{11}$

El 11 de octubre de 2013 el Presidente de la República, Enrique Peña Nieto, turnó al Senado la iniciativa de Ley que Promueve la Paridad de Género en el Congreso Mexicano y con ello reformar el Código Federal de Instituciones y Procedimientos Electorales (COFIPE) para lograr que el 50 por ciento de las candidaturas a diputaciones federales y senadurías de todos los partidos políticos sean de mujeres, al igual que sus suplentes. Para acompañar esta transformación histórica, a través del INMUJERES, se promueve el Empoderamiento Político de las Mujeres e incluso el Instituto cuenta con un Observatorio de la participación política de las mujeres en México. ${ }^{12}$

Es con la reforma constitucional del 2 de febrero de 2014 que se logra la consolidación normativa en materia de paridad de género y el artículo 41 de la Carta Magna da cuenta de ello con el siguiente texto:

1. Los partidos políticos son entidades de interés público; la ley determinará las normas y requisitos para su registro legal, las formas específicas de su intervención en el proceso electoral y los derechos, obligaciones y prerrogativas que les corresponden.

Los partidos políticos tienen como fin promover la participación del pueblo en la vida democrática, contribuir a la integración de los órganos de representación política y como organizaciones de ciudadanos, hacer posible el acceso de éstos al ejercicio del poder público, de acuerdo con los programas, principios e ideas que postulan y mediante el sufragio universal, libre, secreto y directo, así como las reglas para garantizar la paridad entre los géneros, en candidaturas a legisladores federales y locales. Sólo los ciudadanos podrán formar partidos políticos y afiliarse libre e individualmente a ellos; por tanto, quedan prohibidas la intervención de organizaciones gremiales o con objeto social diferente en la creación de partidos y cualquier forma de afiliación corporativa.

\footnotetext{
${ }^{11}$ Ibídem, p. 10.

12 INMUJERES, Observatorio de la participación política de las mujeres en México. México. Disponible en: $<$ http://www.gob.mx/inmujeres/acciones-y-programas/observatorio-de-participacion-politica-de-lasmujeres-en-mexico-21620?idiom=es-MX>.
} 
Con esta modificación, derivada de la iniciativa presentada por el Presidente Enrique Peña Nieto, el Estado Mexicano asume condiciones de apertura y acciones afirmativas inmediatas para alcanzar connotaciones de igualdad. Así,

En este caso, habría que considerar un entramado institucional que abarca en primera instancia los siguientes ámbitos que se vinculan en el proceso de la representación y participación política: a) asignación de candidaturas y ejercicio de liderazgos dentro de los partidos políticos, b) inclusión de mujeres en los espacios legislativos federal y locales, c) presencia efectiva de mujeres en los órganos responsables de la realización y salvaguarda de los procesos electorales, tales como institutos o tribunales. ${ }^{13}$

De este modo las acciones de gobierno en concreto toman forma y fondo en la parte normativa y en su implementación como veremos enseguida.

\section{Reforma electoral en materia de paridad de Género y las nuevas conformaciones en el Congreso Mexicano}

Si hacemos un recuento, con el cambio de régimen y el avance de los procesos democratizadores hacia el año 2000, las mujeres empezaron a ocupar mejores posiciones y espacios tanto en los partidos políticos como en el Congreso Federal para ambas Cámaras, aspecto que fortalece al nuevo Sistema Político en los primeros años del milenio, ya que en el año 2000 se creó la Comisión de Estudios para la Reforma del Estado del Senado de la República con el propósito de impulsar una serie de cambios y modificaciones sustanciales en diversos rubros legislativos.

Sin duda, establecer sistemas de cuotas como medida afirmativa que de manera creciente ha favorecido los espacios de participación de las mujeres en la toma de decisiones legislativas, se han convertido en "...mecanismos de discriminación positiva, las cuotas han implicado dar un tratamiento preferencial a las mujeres. Esta medida tiene un objetivo equilibrador de las desigualdades que enfrentan las mujeres para acceder a cargos políticos, al forzar su ingreso al poder público y no dejarlo completamente a la buena fe de los partidos po-

\footnotetext{
${ }^{13}$ Alarcón Olguín, Víctor, "La equidad de género en el ámbito electoral mexicano", en Ochoa Reza, Enrique (coord.), Equidad de género y derecho electoral en México, México, Tribunal Electoral del Poder Judicial de la Federación, 2009, p. 107.
} 
líticos, ni a sus procedimientos tradicionales de selección".14 Con esta acción los trabajos que en la materia se han discutido y elevado al rango de ley, son avances sustantivos que de manera progresiva construyen normatividad y que de acuerdo con los compromisos de la Cuarta Conferencia Mundial de la Mujer en Beijing 1995, se cumple paulatinamente y de manera obligatoria con “... alcanzar el acceso efectivo de la mujer a los niveles de toma de decisiones políticas en un 50 por ciento para el año 2005...". ${ }^{15}$ Que para el caso mexicano, como ya se ha mencionado, no se consuma sino hasta la reforma lograda en 2014 durante el gobierno del Presidente Enrique Peña Nieto.

Es importante señalar que "...las cuotas de género en materia electoral se introdujeron para lograr un equilibrio de género en las asambleas políticas; estas cuotas asumen principalmente dos formas: cuotas legisladas (o legales) y cuotas de partidos. Las cuotas de género legisladas se han introducido ahora en casi 60 países en el mundo...", ${ }^{16}$ de tal suerte que en México los gobiernos, en particular después del proceso de alternancia y democratización lograron establecer medidas normativas para su legislación e incorporación en la Constitución, en las propias leyes electorales, así como su implementación y mecanismos de sanción.

Una rápida exposición en materia de cuotas de género nos remite al siguiente cuadro:

${ }^{14}$ Peschard, Jacqueline, "Estudio de caso, El sistema de cuotas en América Latina. Panorama general", en IDEA Internacional, Mujeres en el Parlamento. Más allá de los números, Suecia, 2012, p. 174.

${ }^{15}$ Idem. (Las cursivas son propias).

${ }^{16}$ Fredenvall, Lenita, "Cuotas de género en materia electoral como vía rápida a la paridad", En Fredenvall, Lenita et al., Cuotas de género. Visión comparada, México, Tribunal Electoral del Poder Judicial de la Federación, 2013, p. 20. 


\section{Cuadro 1}

\section{AVANCE DE LAS CUOTAS DE GÉNERO EN MÉXICO}

\begin{tabular}{|c|c|c|}
\hline Año & Situación & Acción normativa \\
\hline 1993 & $\begin{array}{l}\text { La participación de las muje- } \\
\text { res en la Cámara de Diputados } \\
\text { oscilaba alrededor del } 15 \% \\
\text { por debajo del umbral reco- } \\
\text { mendado. }\end{array}$ & $\begin{array}{l}\text { Artículo } 175 \text { del COFIPE en } 1993 \text { señalaba únicamente que los partidos políticos deben promover } \\
\text { 'una mayor participación de las mujeres en la vida política del país'. }\end{array}$ \\
\hline 1996 & $\begin{array}{l}\text { La participación de las muje- } \\
\text { res no se incrementó en mayor } \\
\text { medida. }\end{array}$ & $\begin{array}{l}\text { En el COFIPE se incluyó una regla de no otorgar más de } 70 \% \text { de candidaturas a un solo género. } \\
\text { Con ello se logra un ligero incremento de un } 4.8 \% \text {, con lo que se aumentó a un } 18 \% \text { la presencia } \\
\text { femenina en el poder legislativo. }\end{array}$ \\
\hline 2002 & $\begin{array}{l}\text { Los partidos ingresaban can- } \\
\text { didaturas 'simbólicas', como } \\
\text { las candidaturas suplentes, o } \\
\text { colocaban a las candidatas en } \\
\text { los últimos sitios. }\end{array}$ & $\begin{array}{l}\text { La reforma al Código electoral mantiene la cuota en un 70-30, establece su aplicación para las } \\
\text { candidaturas propietarias y no para el total de candidaturas (Propietarios y suplentes en conjunto). } \\
\text { A ello se sumó la regla que obligaba a conformar las listas de candidatos por principio de repre- } \\
\text { sentación proporcional en segmentos de } 3 \text {, y a incluir en los primeros tres segmentos de cada lista } \\
\text { un candidato un género diferente, con ello se garantizaba presencia de por lo menos } 3 \text { mujeres } \\
\text { dentro de los primeros } 9 \text { lugares de la lista. } \\
\text { Se incluyó en el artículo } 175 \text { una sanción por el incumplimiento de la cuota de género, incluyendo } \\
\text { una posible negativa de registro. } \\
\text { Con ello la representación femenina logra el } 23 \% \text { de representación en ambas cámaras. }\end{array}$ \\
\hline 2007 & $\begin{array}{l}\text { Se inicia un importante de- } \\
\text { sarrollo jurisprudencial en } \\
\text { relación a la constitucionali- } \\
\text { dad de las cuotas y a las reglas } \\
\text { para su implementación. }\end{array}$ & $\begin{array}{l}\text { Establecimiento de la cuota obligatoria con el umbral del } 40 \% \text {. Con ello se logró la representación } \\
\text { de las mujeres de } 28 \% \text {, lo que significó un incremento del } 5 \% \text { de la presencia de mujeres con } \\
\text { relación a la legislación anterior. }\end{array}$ \\
\hline 2007 & & $\begin{array}{l}\text { Sentencia SUP-JDC-2580/2007 del Tribunal Electoral del Poder Judicial de la Federación (TEPJF) } \\
\text { se determinó que es legal y constitucional modificar el orden de los candidatos en una lista para } \\
\text { cumplir con el principio de equidad de género. }\end{array}$ \\
\hline 2009 & & $\begin{array}{l}\text { Sentencia SUP-JDC-461/2009 del TEPJF, estableció que el principio de alternancia en el orden de } \\
\text { los candidatos en las listas de representación proporcional debe integrarse en segmentos de cinco } \\
\text { candidatos, por lo que no puede haber más de tres candidatos del mismo género y disponerse de } \\
\text { acuerdo con el principio de alternancia para evitar los lugares consecutivos. }\end{array}$ \\
\hline 2011 & $\begin{array}{l}\text { En septiembre de } 2009, \text { ocho } \\
\text { diputadas pidieron licencia } \\
\text { para dejar su cargo de repre- } \\
\text { sentante popular, en el primer } \\
\text { dí de sesión de trabajo en la } \\
\text { LXI Legislatura. Esto con el } \\
\text { fin de dejar su lugar al mismo } \\
\text { número de hombres. En voz } \\
\text { de Magdy Martinez-Solimán, } \\
\text { coordinador residente del sis- } \\
\text { tema de Naciones Unidas en } \\
\text { México, sostuvo que "México } \\
\text { se merece más respeto a sus } \\
\text { instituciones, a sus diputadas } \\
\text { electas, a sus mujeres y a sus } \\
\text { votantes". }\end{array}$ & $\begin{array}{l}\text { Sentencia SUP-JDC-12624/201l. Con ella la Sala Superior del TEPJF eliminó la excepción a la } \\
\text { cuota en las candidaturas por la vía uninominal, obligando a los partidos a cumplir con la cuota } \\
\text { independientemente del medio interno en la selección de candidatos. } \\
\text { Estableció que dentro del } 40 \% \text { de las candidaturas correspondientes al género minoritario, la } \\
\text { integración de la fórmula a presentarse (propietario y suplente) debía ser del mismo género. } \\
\text { Este punto logró erradicar el fenómeno de las Juanitas. Esta misma sentencia también permitió } \\
\text { fórmulas mixtas con el } 60 \% \text { restante. } \\
\text { Esta medida obligó a los partidos políticos a respetar y garantizar la cuota de género tanto en } \\
\text { las listas de representación proporcional, como en las candidaturas por la vía uninominal, } \\
\text { independientemente del método de elección interna en los partidos políticos. } \\
\text { Con ello la representación de las mujeres en la Cámara de Diputados logró una conformación del } \\
37 \% \text { después de las elecciones federales de } 2012 \text {. }\end{array}$ \\
\hline
\end{tabular}

${ }^{17}$ Sosa, Miguel, "ONU Critica caso de diputadas Juanitas", El Universal, México, 8 de marzo de 2010. Disponible en: <http://archivo.eluniversal.com.mx/notas/664275.html>, Sosa, Miguel, "México se merece más respeto a sus instituciones, a sus diputadas electas, a sus mujeres y a sus votantes", El Universal, México, 8 de marzo de 2010. Disponible en: <http://archivo.eluniversal.com.mx/notas/664275.html>. (Las cursivas son propias). 


\begin{tabular}{|c|c|c|}
\hline Año & Situación & Acción normativa \\
\hline $\begin{array}{l}2013- \\
2014\end{array}$ & $\begin{array}{l}\text { Paridad de Género. Programa Nacional } \\
\text { para la Igualdad de Oportunidades y } \\
\text { no Discriminación contra las Mujeres } \\
\text { 2013-2018. } \\
\text { VI. Participación política y social } \\
\text { La Ley General para la Igualdad entre } \\
\text { Mujeres y Hombres establece como } \\
\text { objetivo proponer los lineamientos y } \\
\text { mecanismos institucionales que orien- } \\
\text { ten el cumplimiento de la igualdad } \\
\text { sustantiva en los ámbitos público y } \\
\text { privado, promover el empoderamiento } \\
\text { de las mujeres, así como la participación } \\
\text { y representación política equilibrada de } \\
\text { mujeres y hombres. } \\
\text { La participación de las mujeres en el } \\
\text { ámbito político a nivel federal presenta } \\
\text { avances. El Tribunal Electoral del } \\
\text { Poder Judicial de la Federación emitió } \\
\text { la sentencia 12624/201l que estipula la } \\
\text { obligatoriedad de las cuotas de género, } \\
\text { así como la integración de fórmulas con } \\
\text { suplencias del mismo sexo, establecidas } \\
\text { en las modificaciones al Código Federal } \\
\text { de Instituciones y Procedimientos } \\
\text { Electorales (coFipE). Gracias a ello, en } \\
\text { 2012, la representación de mujeres en la } \\
\text { Cámara de Senadores alcanzó } 33.6 \% \text { y } \\
\text { en la Cámara de Diputados } 36.8 \% \text {; con } \\
\text { ello se cumple a nivel federal uno de los } \\
\text { ODMs, de alcanzar un mínimo de } 30 \% \\
\text { de mujeres en el Congreso. } \\
\text { Sin embargo, en los poderes locales, } \\
\text { representados por las presidencias mu- } \\
\text { nicipales, la participación de las mujeres } \\
\text { en } 2013 \text { es de apenas un } 6.9 \text { por ciento; } \\
\text { las regidoras y síndicas representaban } \\
\text { en } 2011 \text { un } 38.5 \% \text { y un } 26.8 \% \text {. En este } \\
\text { ámbito se debe considerar la necesidad } \\
\text { de incrementar la participación de las } \\
\text { mujeres indígenas y generar estrategias } \\
\text { que las lleven a conocer sus derechos. }\end{array}$ & 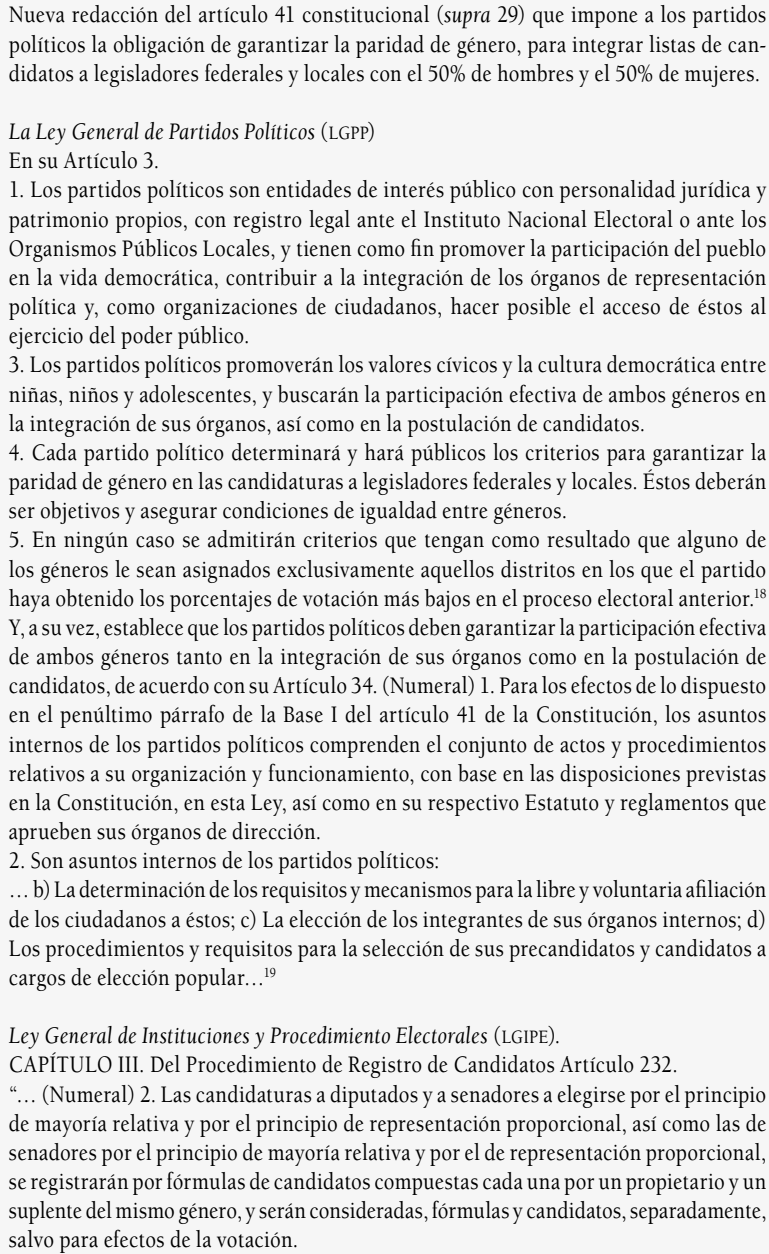 \\
\hline
\end{tabular}

${ }^{18}$ Cámara de Diputados, Ley General de Instituciones y Procedimientos Electorales. Nueva Ley publicada en el Diario Oficial de la Federación el 23 de mayo de 2014. Declaratoria de invalidez de artículos por Sentencia de la SCJN notificada para efectos legales 10-09-2014 y publicada en el DOF 13-08-2015, p. 104. Disponible en: <http://www.diputados.gob.mx/LeyesBiblio/pdf/LGIPE_130815.pdf>.

${ }^{19}$ Ibídem, p. 16. 


\begin{tabular}{|c|c|c|}
\hline Año & Situación & Acción normativa \\
\hline $\begin{array}{l}2013- \\
2014\end{array}$ & $\begin{array}{l}\text { La presencia de mujeres en } \\
\text { los poderes ejecutivos de } \\
\text { los tres órdenes de gobier- } \\
\text { no se encuentra lejos de la } \\
\text { paridad, del total de perso- } \\
\text { nas en puestos directivos } \\
\text { superiores, las mujeres no } \\
\text { alcanzan ni un 24\%. En cuan- } \\
\text { to al Ejecutivo Federal, la } \\
\text { participación femenina en los } \\
\text { mandos medios y superiores } \\
\text { representa apenas el } 35.5 \% \text { y } \\
\text { se concentra en la más baja } \\
\text { jerarquía (subdirectoras,jefas } \\
\text { de departamento, enlaces). } \\
\text { La representación femenina } \\
\text { en las entidades federativas } \\
\text { en puestos de alta dirección } \\
\text { apenas alcanza un } 14.6 \% \text {. } \\
\text { En la Suprema Corte de Jus- } \\
\text { ticia Nacional, sólo } 2 \text { de los } \\
\text { ll ministros son mujeres. De } \\
\text { los magistrados del Pleno de } \\
\text { los Tribunales Superiores de } \\
\text { Justicia en 2012, 28.6\% eran } \\
\text { mujeres. } \\
\text { Finalmente, la participación } \\
\text { de las mujeres en puestos } \\
\text { de toma de decisión en las } \\
\text { estructuras sindicales es de } \\
\text { menos de un } 4 \% \text {. }\end{array}$ & 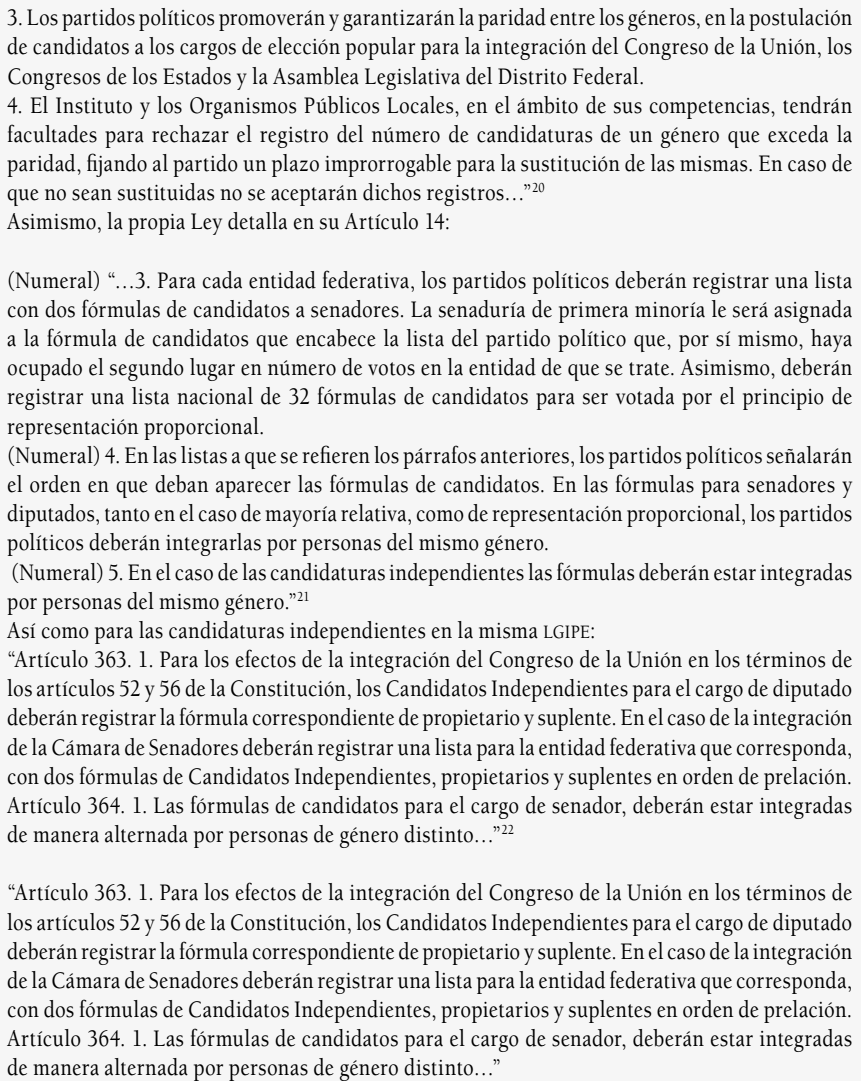 \\
\hline
\end{tabular}

Fuente: Elaboración propia con base en la información de Gilas, Karolina Monika, "Hacia una nueva época. Paridad de género en la reforma electoral 2014", en González Madrid, Miguel y Escamilla Cadena, Alberto (coords.), El nuevo Sistema Político Electoral Mexicano en 2015, México, Universidad Autónoma Metropolitana, Iztapalapa, 2015, pp. $190-192$.

${ }^{20}$ Cámara de Diputados, Ley General de Instituciones y Procedimientos Electorales. Nueva Ley publicada en el Diario Oficial de la Federación el 23 de mayo de 2014. Declaratoria de invalidez de artículos por Sentencia de la SCJN notificada para efectos legales 10-09-2014 y publicada en el DOF 13-08-2015, p. 104. Disponible en: <http://www.diputados.gob.mx/LeyesBiblio/pdf/LGIPE_130815.pdf>.

${ }^{21}$ Ibídem, p. 5.

${ }^{22}$ Cámara de Diputados, Ley General de Instituciones y Procedimientos Electorales, op. cit., p. 155. 
Con estos elementos podemos apreciar una paulatina pero significativa transformación legislativa que se ha llevado a cabo a lo largo de poco más de 20 años de trabajo y de persistencia desde el orden institucional para hacer perfilar mejores condiciones de equidad en un inicio, paridad y finalmente de igualdad de género en términos normativos.

De acuerdo con las siguientes tablas, el incremento porcentual de la participación de las mujeres en el Congreso Mexicano a partir de 1997, se puede apreciar como sigue:

Cuadro 2

COMPOSICIÓN POR SEXO DE LAS LEGISLATURAS LVI-LXIII EN LA CÁMARA DE DIPUTADOS

\begin{tabular}{|c|c|c|c|c|c|c|}
\hline & & & \multicolumn{2}{|c|}{ Absolutos } & \multicolumn{2}{c|}{ Porcentajes } \\
\hline Legislatura & Años & Total & Hombres & Mujeres & Hombres & Mujeres \\
\hline LVI & $1994-1997$ & 496 & 424 & 72 & 85.4 & 14.6 \\
\hline LVII & $1997-2000$ & 500 & 413 & 87 & 82.6 & 17.4 \\
\hline LVIII & $2000-2003$ & 500 & 416 & 84 & 83.2 & 16.8 \\
\hline LIX & $2003-2006$ & 498 & 374 & 124 & 75.1 & 24.9 \\
\hline LX & $2006-2009$ & 500 & 371 & 129 & 74.2 & 25.8 \\
\hline LXI & $2009-2012$ & 491 & 335 & 156 & 68.22 & 31.77 \\
\hline LXII & $2012-2015$ & 500 & 316 & 184 & 63.2 & 36.8 \\
\hline LXIII & $2015-2018$ & 500 & 288 & 212 & 57.6 & 42.4 \\
\hline
\end{tabular}

Fuentes: Para 1994 a 2012: Presidencia de la República, Sexto Informe de Gobierno, 2012. Anexo Estadístico. II. Estadísticas Nacionales. Igualdad de Oportunidades, p. 350.

Para 2012 a 2015: Cámara de Diputados, "Integración por género y Grupo Parlamentario". Disponible en: <www. diputados.gob.mx>.

Para 2015 a 2018: Cámara de Diputados. "Integración por género y Grupo Parlamentario". Disponible en: <http://sitl. diputados.gob.mx/LXIII_leg/cuadro_genero.php>. 
Cuadro 3

COMPOSICIÓN POR SEXO DE LAS LEGISLATURAS LVI-LXIII EN LA CÁMARA DE SENADORES

\begin{tabular}{|c|c|c|c|c|c|c|}
\hline & & & \multicolumn{2}{|c|}{ Absolutos } & \multicolumn{2}{c|}{ Porcentajes } \\
\hline Legislatura & Años & Total & Hombres & Mujeres & Hombres & Mujeres \\
\hline LVI & $1994-1997$ & 128 & 115 & 13 & 89.8 & 10.2 \\
\hline LVII & $1997-2000$ & 128 & 108 & 20 & 84.4 & 15.6 \\
\hline LVIII & $2000-2003$ & 128 & 105 & 23 & 82.0 & 18.0 \\
\hline LIX & $2003-2006$ & 127 & 96 & 31 & 75.6 & 24.4 \\
\hline LX & $2006-2009$ & 128 & 104 & 24 & 81.2 & 18.8 \\
\hline LXI & $2009-2012$ & 124 & 96 & 28 & 77.4 & 22.6 \\
\hline LXII & $2012-2015$ & 128 & 105 & 23 & 82.0 & 18.0 \\
\hline LXIII & $2015-2018$ & 128 & 86 & 42 & 67 & 33 \\
\hline
\end{tabular}

Fuentes: Secretaría de Gobernación, "Sistema de Información Legislativa". Disponible en: <http://sil.gobernacion. gob.mx/portal>.

INEGI. Disponible en:<www.inegi.gob.mx>.

Para los periodos de 1964 a 2003: Presidencia de la República, Tercer Informe de Gobierno, 2003. Anexo Estadístico. Para el periodo 2003 a 2006: Senado de la República. Disponible en: <http://www.senado.gob.mx>.

Para el período 2009 a 2012: Senado de la República. Disponible en: <http://www.senado.gob.mx>

Para el periodo 2012 a 2015 y 2015 a 2018: Senado de la República, "Información Histórica": Disponible en: <http:// www.senado.gob.mx/index.php?ver=sen $\& \mathrm{mn}=9 \& \mathrm{sm}=\mathrm{l}>$.

Sin duda la composición legislativa obtiene mayor reconocimiento y condiciones de paridad. Ahora bien, el trabajo legislativo de manera reciente, además del compromiso con la equidad, también juega un papel importante en la discusión y aprobación de iniciativas que a la postre se convertirán en leyes tanto en materia de género, así como en otros rubros. De ahí que la participación e incidencia en la toma de decisiones de las mujeres en el trabajo legislativo cobre mayor peso.

La conformación de las comisiones de ambas Cámaras en el actual gobierno adquiere relevancia en la medida que la integración la ocupa una mayoría amplia del Partido Revolucionario Institucional. Ambas Cámaras cuentan con Comisiones Ordinarias, Especiales y Bicamerales, que en esta condición pueden garantizar que las iniciativas presentadas por el Ejecutivo sean discutidas y valoradas de manera positiva antes de pasar al pleno. 


\section{Cuadro 4}

CÁMARA DE DIPUTADOS LXII LEGISLATURA 2012-2015. INTEGRACIÓN POR GÉNERO Y POR GRUPO PARLAMENTARIO

\begin{tabular}{|l|c|c|}
\hline $\begin{array}{c}\text { Grupo } \\
\text { Parlamentario }\end{array}$ & Hombres & $\%$ \\
\hline PRI & 116 & 54.2 \\
\hline PAN & 72 & 63.7 \\
\hline PRD & 62 & 62.6 \\
\hline PVEM & 16 & 59.3 \\
\hline MC & 6 & 50.0 \\
\hline PT & 6 & 54.5 \\
\hline NA & 5 & 50.0 \\
\hline MORENA & 8 & 66.7 \\
\hline Sin partido & 2 & 100.0 \\
\hline Total & 293 & 58.6 \\
\hline
\end{tabular}

\begin{tabular}{|c|c|}
\hline Mujeres & $\%$ \\
\hline 98 & 45.8 \\
\hline 41 & 36.3 \\
\hline 37 & 37.4 \\
\hline 11 & 40.7 \\
\hline 6 & 50.0 \\
\hline 5 & 45.5 \\
\hline 5 & 50.0 \\
\hline 4 & 33.3 \\
\hline 0 & 0.0 \\
\hline 207 & 41.4 \\
\hline
\end{tabular}

\begin{tabular}{|c|c|}
\hline Total & $\%$ \\
\hline 214 & 100.0 \\
\hline 113 & 100.0 \\
\hline 99 & 100.0 \\
\hline 27 & 100.0 \\
\hline 12 & 100.0 \\
\hline 11 & 100.0 \\
\hline 10 & 100.0 \\
\hline 12 & 100.0 \\
\hline 2 & 100.0 \\
\hline 500 & 100.0 \\
\hline
\end{tabular}

Fuente: Cámara de Diputados, "Álbum de Diputados Federales 2015-2018". Disponible en: <http://sitl.diputados.gob. mx/LXII_leg/album_foto_tc.pdf>.

Cuadro 5.

CÁMARA DE DIPUTADOS LXIII LEGISLATURA 2015-2018 INTEGRACIÓN POR GÉNERO Y POR GRUPO PARLAMENTARIO

\begin{tabular}{|l|c|c|}
\hline $\begin{array}{c}\text { Grupo } \\
\text { Parlamentario }\end{array}$ & Hombres & $\%$ \\
\hline PRI & 119 & 57.2 \\
\hline PAN & 62 & 56.9 \\
\hline PRD & 38 & 63.3 \\
\hline PVEM & 26 & 61.9 \\
\hline MORENA & 17 & 47.2 \\
\hline MC & 14 & 56.0 \\
\hline NA & 6 & 54.5 \\
\hline PES & 5 & 62.5 \\
\hline Independiente & 1 & 100.0 \\
\hline Total & 288 & 57.6 \\
\hline
\end{tabular}

\begin{tabular}{|c|c|}
\hline Mujeres & $\%$ \\
\hline 89 & 42.8 \\
\hline 47 & 43.1 \\
\hline 22 & 36.7 \\
\hline 16 & 38.1 \\
\hline 19 & 52.8 \\
\hline 11 & 44.0 \\
\hline 5 & 45.5 \\
\hline 3 & 37.5 \\
\hline 0 & 0.0 \\
\hline 212 & 42.4 \\
\hline
\end{tabular}

\begin{tabular}{|c|c|}
\hline Total & $\%$ \\
\hline 208 & 100.0 \\
\hline 109 & 100.0 \\
\hline 60 & 100.0 \\
\hline 42 & 100.0 \\
\hline 36 & 100.0 \\
\hline 25 & 100.0 \\
\hline 11 & 100.0 \\
\hline 8 & 100.0 \\
\hline 1 & 100.0 \\
\hline 500 & 100.0 \\
\hline
\end{tabular}

Fuente: Cámara de Diputados, "Álbum de Diputados Federales 2015-2018". Disponible en: <http://sitl.diputados.gob. mx/LXIII_leg/album_foto_tc.pdf>. 


\section{Cuadro 6}

CÁMARA DE SENADORAS/ES DE LA LXII LEGISLATURA, POR SEXO, CONFORMACIÓN ACTUAL ACTUALIZACIÓN DE ABRIL DE 2013 CONFORMACIÓN DE LA CÁMARA DE SENADORAS/ES POR SEXO (2013)

\begin{tabular}{|l|c|c|c|}
\hline \multirow{2}{*}{$\begin{array}{c}\text { Grupo } \\
\text { Parlamentario }\end{array}$} & \multicolumn{3}{|c|}{ Total del Senado } \\
\cline { 2 - 4 } & Mujeres (\%) & Hombres (\%) & Total \\
\hline PAN & $12(32 \%)$ & $26(68 \%)$ & 58 \\
\hline PRI & $20(37 \%)$ & $34(63 \%)$ & 22 \\
\hline PRD & $6(27 \%)$ & $16(73 \%)$ & 5 \\
\hline PT & $2(40 \%)$ & $3(60 \%)$ & 7 \\
\hline PVEM & $2(29 \%)$ & $5(71 \%)$ & 1 \\
\hline $\begin{array}{l}\text { MOVIMIENTO } \\
\text { CIUDADANO }\end{array}$ & $1(50 \%)$ & $0(50 \%)$ & 1 \\
\hline NUEVA ALIANZA & $1(100 \%)$ & $0(0 \%)$ & 128 \\
\hline Total & $44(34.4 \%)$ & $84(65.6 \%)$ & 5 \\
\hline
\end{tabular}

Fuente: Elaborado por el Centro para el Desarrollo Democrático del IFE con base en datos de la Cámara de Senadores, disponible en: <http://www.senado.gob.mx/?ver=int\&mn=9\&sm=2\&str=T> y del Sistema de Información Legislativa de la Secretaría de Gobernación. Disponible en: <http://sil.gobernacion.gob.mx/Numeralia/Legisladores/ NumeraliaLegisladores.php?SID=>.

\section{Cuadro 7}

CONFORMACIÓN DE LA CÁMARA DE SENADORAS/ES POR SEXO Y PRINCIPIO DE ELECCIÓN (2013)

\begin{tabular}{|c|c|c|c|c|c|c|c|c|c|}
\hline \multirow{2}{*}{$\begin{array}{c}\text { Grupo } \\
\text { Parlamentario }\end{array}$} & \multicolumn{3}{|c|}{ Mayoría Relativa } & \multicolumn{3}{|c|}{ Primera Minoría } & \multicolumn{3}{|c|}{ Representación Proporcional } \\
\hline & $\begin{array}{c}\text { Mujeres } \\
(\%)\end{array}$ & $\begin{array}{c}\text { Hombres } \\
(\%)\end{array}$ & Total & $\begin{array}{c}\text { Mujeres } \\
(\%)\end{array}$ & $\begin{array}{c}\text { Hombres } \\
(\%)\end{array}$ & Total & $\begin{array}{c}\text { Mujeres } \\
(\%)\end{array}$ & $\begin{array}{c}\text { Hombres } \\
(\%)\end{array}$ & Total \\
\hline PAN & $\begin{array}{c}5 \\
(31 \%)\end{array}$ & $\begin{array}{c}11 \\
(69 \%)\end{array}$ & 16 & $\begin{array}{c}2 \\
(15 \%)\end{array}$ & $\begin{array}{c}11 \\
(85 \%)\end{array}$ & 13 & $\begin{array}{c}5 \\
(56 \%)\end{array}$ & $\begin{array}{c}4 \\
(44 \%)\end{array}$ & 9 \\
\hline PRI & $\begin{array}{c}13 \\
(41 \%)\end{array}$ & $\begin{array}{c}19 \\
(59 \%)\end{array}$ & 32 & $\begin{array}{c}2 \\
(18 \%)\end{array}$ & $\begin{array}{c}9 \\
(82 \%)\end{array}$ & 11 & $\begin{array}{c}5 \\
(45 \%)\end{array}$ & $\begin{array}{c}6 \\
(55 \%)\end{array}$ & 11 \\
\hline PRD & $\begin{array}{c}2 \\
(18 \%) \\
\end{array}$ & $\begin{array}{c}9 \\
(82 \%) \\
\end{array}$ & 11 & $\begin{array}{c}1 \\
(20 \%)\end{array}$ & $\begin{array}{c}4 \\
(80 \%) \\
\end{array}$ & 5 & $\begin{array}{c}3 \\
(50 \%) \\
\end{array}$ & $\begin{array}{c}3 \\
(50 \%) \\
\end{array}$ & 6 \\
\hline PT & $\begin{array}{c}1 \\
(100 \%)\end{array}$ & $\begin{array}{c}0 \\
(0 \%)\end{array}$ & 1 & $\begin{array}{c}0 \\
(0 \%) \\
\end{array}$ & $\begin{array}{c}2 \\
(100 \%) \\
\end{array}$ & 2 & $\begin{array}{c}1 \\
(3 \%)\end{array}$ & $\begin{array}{c}1 \\
(3 \%)\end{array}$ & 2 \\
\hline PVEM & $\begin{array}{c}1 \\
(25 \%)\end{array}$ & $\begin{array}{c}3 \\
(75 \%) \\
\end{array}$ & 4 & $\begin{array}{c}0 \\
(0 \%) \\
\end{array}$ & $\begin{array}{c}1 \\
(100 \%)\end{array}$ & 1 & $\begin{array}{c}1 \\
(50 \%) \\
\end{array}$ & $\begin{array}{c}1 \\
(50 \%) \\
\end{array}$ & 2 \\
\hline $\begin{array}{l}\text { MOVIMIENTO } \\
\text { CIUDADANO }\end{array}$ & $\begin{array}{c}0 \\
(0 \%)\end{array}$ & $\begin{array}{c}0 \\
(0 \%)\end{array}$ & 0 & $\begin{array}{c}0 \\
(0 \%)\end{array}$ & $\begin{array}{c}0 \\
(0 \%)\end{array}$ & 0 & $\begin{array}{c}1 \\
(100 \%)\end{array}$ & $\begin{array}{c}0 \\
(0 \%)\end{array}$ & 1 \\
\hline NUEVA ALIANZA & $\begin{array}{c}0 \\
(0 \%) \\
\end{array}$ & $\begin{array}{c}0 \\
(0 \%)\end{array}$ & 0 & $\begin{array}{c}0 \\
(0 \%)\end{array}$ & $\begin{array}{c}0 \\
(0 \%)\end{array}$ & 0 & $\begin{array}{c}1 \\
(100 \%)\end{array}$ & $\begin{array}{c}0 \\
(0 \%)\end{array}$ & 1 \\
\hline Total & $\begin{array}{c}22 \\
(34 \%)\end{array}$ & $\begin{array}{c}42 \\
(66 \%)\end{array}$ & 64 & $\begin{array}{c}5 \\
(16 \%)\end{array}$ & $\begin{array}{c}27 \\
(84 \%)\end{array}$ & 32 & $\begin{array}{c}17 \\
(53 \%)\end{array}$ & $\begin{array}{c}15 \\
(47 \%)\end{array}$ & 32 \\
\hline
\end{tabular}

Fuente: Elaborado por el Centro para el Desarrollo Democrático del IFE con base en datos de la Cámara de Senadores, disponible en: <http://www.senado.gob.mx/?ver=int\&mn=9\&sm=2\&str=T> y del Sistema de Información Legislativa de la Secretaría de Gobernación. Disponible en: <http://sil.gobernacion.gob.mx/Numeralia/Legisladores/ NumeraliaLegisladores.php?SID=>. 
Sin duda estos resultados representan un puntual seguimiento a las modificaciones normativas establecidas y precisadas por los organismos electorales, el Instituto Nacional Electoral y el Tribunal Electoral del Poder Judicial, así como por las instancias encargadas de su atención, dependientes del propio Ejecutivo Federal como el INMUJERES. Podemos decir que "...las cuotas son sólo puntas de lanza que preparan el terreno para que se desarrollen políticas y programas públicos de atención a las demandas de las mujeres, como condición necesaria para que se construyan sociedades más igualitarias cuya expresión política sea la democracia paritaria". ${ }^{23}$ Asimismo, significan para el Presidente de la República en turno un importante capital político favorecido por las legisladoras priístas en ambas Cámaras, así como las alianzas del partido con las mujeres de las otras fuerzas políticas cercanos al Revolucionario Institucional como el Partido Verde.

En estas condiciones las cuotas logran reducir la brecha entre géneros en el espacio público y favorecen la construcción de representación política, sin embargo, aún quedan por cubrir, en todas sus dimensiones, espacios a ser ocupados por mujeres, de tal suerte que "...la paridad entre los géneros sólo se logrará... cuando las mujeres participen plenamente y en pie de igualdad de todos los sectores de la vida pública y privada, logrando así tener la sociedad sostenible, pacífica, justa y anhelada para todos y todas". ${ }^{24}$ La importancia de esta indispensable condición de igualdad se alcanza en México a partir de lo que se puede llamar la "vía rápida de paridad", o el medio para llegar a una condición de paridad electoral 50\% mujeres, 50\% hombres; y con ello resolver el problema de la subrepresentación de las mujeres en el Congreso Mexicano, sin que necesariamente implique condiciones reales de igualdad sustantiva en todos los aspectos: familiares, sociales, laborales y sin duda, culturales, que de no atenderse, derivan en violencia, abuso, abandono y discriminación, sin duda legislar implica promover formas de vida más favorables para las mujeres. En este sentido es importante precisar que:

La vía de incremento y la vía rápida no sólo representan dos diferentes explicaciones de la velocidad actual del desarrollo histórico en la representación política de las mujeres. También pueden ser vistas como dos clases diferentes de política de igualdad de género, donde una promueve la igualdad formal en función del principio de igualdad de género como igualdad de resultados.

${ }^{23}$ Peschard, Jacqueline, "Estudio de caso, El sistema de cuotas en América Latina. Panorama general", op. cit., p. 184.

${ }^{24}$ Fredenvall, Lenita, "Cuotas de género en materia electoral como vía rápida a la paridad", op. cit., p. 16. 
Las dos vías también pueden ser vistas como la participación de dos modelos, interpretados como una distinción analítica entre dos tipos ideales, que se basan en identificaciones de problemas diferentes respecto al diagnóstico de la subrepresentación de las mujeres, diferentes metas en términos de representación política de las mujeres y, como consecuencia, estrategias políticas distintas para lograr el cambio. ${ }^{25}$

En una primera fase el proceso de reforma político electoral para avanzar en materia de paridad de género cruzó desde 1993 por paulatinos incrementos que inician con una recomendación, puesta en el COFIPE, dirigida a los partidos políticos para promover la participación de las mujeres en sus filas, así como en la vida política del país, y de ahí lanzarlas a posibles candidaturas. Esta práctica tuvo un progresivo incremento para arribar en 2002 al 30 por ciento y hacia 2007 llegar al 40 por ciento, con sus indiscutibles salvedades, recordemos el caso de las llamadas Juanitas, en los procesos de asignación de espacios y de registro para las candidaturas en competencia. Desde la propia discriminación interna en los partidos políticos para integrar a las mujeres militantes en probables planillas ganadoras, así como la inconsistencia de los elementos normativos tanto constitucionales como en materia electoral, que fueron indispensables revisar y reformar para afianzar procesos más sólidos en materia de equidad de género y solventar la constante subrepresentación. Si bien se manifestaron logros en el inter de 2007-2014 en este rubro, también hubo evidencia de ausencia de participación política por parte de las mujeres para insertarse en procesos políticos electorales relevantes, basta tener presente la tremenda subrepresentación de mujeres en cargos de elección popular a nivel municipal como alcaldesas, sumado sin duda a la violencia política de género que se ha convertido no sólo un problema y en un delito por sí mismo; sino en un mecanismo deplorable de desmotivación para que las mujeres se incorporen en campañas políticas como activas protagonistas.

La iniciativa turnada por el Ejecutivo Federal en 2013 y aprobada en 2014 para alcanzar esta paridad por la vía rápida y superar la brecha de la subrepresentación en las elecciones federales de 2015, también habla de un esquema de compensación política y de consolidación democrática en la propia lógica de una Reforma del Estado en materia electoral, digamos, relativamente exitosa para el Presidente Peña, tomando en cuenta que la representación igualitaria no

${ }^{25}$ Ibídem, p. 45. 
se logra del todo en este primer intento. Sin duda se requiere no sólo de la incorporación de medidas afirmativas como una acción impaciente asociada al logro inmediato de condiciones de paridad en un marco democrático, ya que los otros rubros asociados a mejores condiciones de vida, de trabajo, de reparto de tareas, de conciliación entre la vida laboral y familiar, así como de mejores oportunidades y de erradicación de la violencia hacia las mujeres, no está asimilado en el entorno social y atendido a cabalidad, así la consolidación de paridad por la vía rápida sólo podría quedar en la consumación del discurso político. A nivel de cumplimiento de encomiendas internacionales, CEDAW 1979, Beijing 1995, y de un comparativo con otros países de la región e incluso con los países nórdicos, que han logrado durante décadas arribar a condiciones de paridad efectiva tanto en los rubros electorales como de la vida cotidiana, México ya se inserta entre las naciones con paridad de género.

Ahora bien, con las cifras que se han referido en los cuadros que acompañan este apartado, vale la pena perfilar cuál es el capital político que con las mujeres en el Congreso Federal logra el Presidente de la República, en particular con las mujeres priístas y las alianzas. Durante la primera mitad del actual gobierno, la Cámara de Diputados en su LXII Legislatura, 2012-2015, quedó integrada por 207 mujeres y 293 hombres, de las cuales 98 pertenecieron al PRI y 11 al PVEM, para un total de 109 mujeres que en alianza pudieran favorecer iniciativas presidenciales, no sólo en materia de género, sino en la diversidad de rubros que ocupan a las diferentes comisiones que integran a la Cámara de Diputados. Por lo que toca al número de hombres, 116 pertenecían al PRI y 16 al PVEM, para integrar a 132 legisladores afines, por naturaleza, a las iniciativas presidenciales. Es decir, un total de 241 legisladores entre hombre y mujeres afines al gobierno en turno, en términos legislativos representaban el $48.2 \%$ del Congreso, frente al resto de la oposición conformada por el $51.8 \%$ de los legisladores distribuidos entre el resto de los partidos. Sin duda el trabajo para generar sinergias entre la oposición y promover las iniciativas presidenciales van de la mano con la habilidad política del líder de la bancada y su capacidad para construir acuerdos, sin dejar de lado la propia habilidad del Presidente.

Las Comisiones de la LXII Legislatura de la Cámara de Diputados se dividieron en el siguiente orden: 


\section{Cuadro 8}

DISTRIBUCIÓN DE PRESIDENCIAS POR GRUPO PARLAMENTARIO

LXII LEGISLATURA CÁMARA DE DIPUTADOS, 2012-2015

\begin{tabular}{|l|c|c|c|c|c|c|c|c|c|c|c|c|}
\hline $\begin{array}{c}\text { Grupo } \\
\text { Parlamentario }\end{array}$ & Ordinaria & $\%$ & Especial & $\%$ & Bicamaral & $\%$ & Investigación & $\%$ & Comité & $\%$ & Total & $\%$ \\
\hline PRI & 24 & 42.9 & 14 & 37.8 & 2 & 50 & 0 & 0 & 4 & 50 & 44 & 41.1 \\
\hline PAN & 13 & 23.2 & 8 & 21.6 & 2 & 50 & 0 & 0 & 1 & 12.5 & 24 & 22.4 \\
\hline PRD & 11 & 19.6 & 7 & 18.9 & 0 & 0 & 2 & 100 & 2 & 25 & 22 & 20.6 \\
\hline PVEM & 3 & 5.4 & 4 & 10.8 & 0 & 0 & 0 & 0 & 0 & 0 & 7 & 6.5 \\
\hline MC & 2 & 3.6 & 1 & 2.7 & 0 & 0 & 0 & 0 & 0 & 0 & 3 & 2.8 \\
\hline PT & 1 & 1.8 & 1 & 2.7 & 0 & 0 & 0 & 0 & 1 & 12.5 & 3 & 2.8 \\
\hline NA & 1 & 1.8 & 2 & 5.4 & 0 & 0 & 0 & 0 & 0 & 0 & 3 & 2.8 \\
\hline MORENA & 1 & 1.8 & 0 & 0 & 0 & 0 & 0 & 0 & 0 & 0 & 1 & 0.9 \\
\hline Total & 56 & 100 & 37 & 100 & 4 & 100 & 2 & 100 & 8 & 100 & 107 & 100 \\
\hline
\end{tabular}

Fuente: Distribución de Presidencias por Grupo Parlamentario. Comisión y Comités LXII Legislatura. Disponible en: $<$ http://sitl.diputados.gob.mx/LXII_leg/cuadro_presidenciaslxii.php>.

Nos centraremos, de manera breve para este trabajo, en las Comisiones Ordinarias presididas por mujeres de las 56 que integraron la LXII Legislatura de la Cámara de Diputados y son las siguientes:

\section{Cuadro 9}

COMISIONES ORDINARIAS PRESIDIDAS POR MUJERES

LXII LEGISLATURA DE LA CÁMARA DE DIPUTADOS, 2012-2015

\begin{tabular}{|c|c|c|c|c|c|}
\hline Comisión & Nombre Presidenta & Partido & $\begin{array}{c}\text { Tipo de } \\
\text { elección }\end{array}$ & Suplente \\
\hline Asuntos Indígenas & Eufrosina Cruz Mendoza & PAN & RP & $\begin{array}{c}\text { Cecilia Laviada } \\
\text { Hernández }\end{array}$ \\
\hline $\begin{array}{c}\text { Asuntos Migratorios } \\
\text { Atención a Grupos } \\
\text { Vulnerables }\end{array}$ & $\begin{array}{c}\text { Lorenia Iveth Valles } \\
\text { Sampedro } \\
\text { Cristina Ruíz Sandoval }\end{array}$ & PRD & RP & $\begin{array}{c}\text { Claudia Janneth Gámez } \\
\text { Gutiérrez }\end{array}$ \\
\hline $\begin{array}{c}\text { Cultura y } \\
\text { Cinematografía }\end{array}$ & $\begin{array}{c}\text { Margarita Saldaña } \\
\text { Hernández }\end{array}$ & PAN & RP & Maribel Martínez \\
Altamirano
\end{tabular}




\begin{tabular}{|c|c|c|c|c|c|}
\hline Comisión & Nombre Presidenta & Partido & $\begin{array}{l}\text { Tipo de } \\
\text { elección }\end{array}$ & Suplente & Entidad \\
\hline Derechos de la Niñez & $\begin{array}{c}\text { Verónica Beatriz Juárez } \\
\text { Piña }\end{array}$ & PRD & $\mathrm{RP}$ & $\begin{array}{c}\text { Ana Sofía Méndez } \\
\text { Noriega }\end{array}$ & Jalisco \\
\hline $\begin{array}{c}\text { Desarrollo Urbano } \\
\text { y Ordenamiento } \\
\text { Territorial }\end{array}$ & $\begin{array}{c}\text { Celia Isabel Gauna Ruiz } \\
\text { de León }\end{array}$ & PRI & MR & $\begin{array}{l}\text { Mariana Guadalupe } \\
\text { Flores Álvarez }\end{array}$ & Jalisco \\
\hline $\begin{array}{l}\text { Hacienda y Crédito } \\
\text { Público }\end{array}$ & $\begin{array}{c}\text { Aurora de la Luz Aguilar } \\
\text { Rodríguez }\end{array}$ & PAN & $\mathrm{RP}$ & Viviana Burle Migon & Tlaxcala \\
\hline Igualdad de Género & $\begin{array}{l}\text { Martha Lucía Mícher } \\
\text { Camarena }\end{array}$ & PRD & MR & $\begin{array}{c}\text { Martha Ofelia Zamarripa } \\
\text { Rivas }\end{array}$ & Distrito Federal \\
\hline Marina & Adriana Soto Martínez & $\begin{array}{l}\text { Movimiento } \\
\text { Ciudadano }\end{array}$ & MR & José Soto Martínez & Oaxaca \\
\hline $\begin{array}{l}\text { Medio ambiente y } \\
\text { Recursos Naturales }\end{array}$ & $\begin{array}{c}\text { Lourdes Adriana López } \\
\text { Moreno }\end{array}$ & PVEM & MR & Leticia Pérez Guzmán & Chiapas \\
\hline Protección Civil & $\begin{array}{c}\text { Martha Beatriz Córdova } \\
\text { Bernal }\end{array}$ & $\begin{array}{l}\text { Movimiento } \\
\text { Ciudadano }\end{array}$ & $\mathrm{RP}$ & Celia García Lizardi & Chihuahua \\
\hline Recursos Hidráulicos & $\begin{array}{c}\text { Angélica Rocío Melchor } \\
\text { Vásquez }\end{array}$ & PRD & $\mathrm{RP}$ & $\begin{array}{c}\text { Saraí Larisa León } \\
\text { Montero }\end{array}$ & Oaxaca \\
\hline Reforma Agraria & $\begin{array}{c}\text { María del Socorro Ceseñas } \\
\text { Chapa }\end{array}$ & PRD & $\mathrm{RP}$ & $\begin{array}{c}\text { Rosa María Villarreal } \\
\text { Garza }\end{array}$ & Nuevo León \\
\hline $\begin{array}{l}\text { Transparencia y } \\
\text { Anticorrupción }\end{array}$ & Areli Madrid Tovilla & PRI & $\mathrm{RP}$ & $\begin{array}{c}\text { Ana Guadalupe Ingram } \\
\text { Vallines }\end{array}$ & Chiapas \\
\hline
\end{tabular}

Fuente: Elaboración propia con datos de Listado de Comisiones Ordinarias, LXII Legislatura, Disponible en: <http:// sitl.diputados.gob.mx/LXII_leg/listado_de_comisioneslxii.php?tct=l>.

Sólo 14 de las 56 Comisiones, 25 por ciento, fueron presididas por mujeres, de las cuales 3 encabezó el PRI y una el PVEM, las 10 restantes fueron encabezadas por mujeres de la oposición.

Con relación a las comisiones ordinarias de la Cámara de Diputados de la LXIII legislatura, 2015-2018, encontramos los siguientes datos: 


\section{Cuadro 10}

DISTRIBUCIÓN DE PRESIDENCIAS POR GRUPO PARLAMENTARIO

LXIII LEGISLATURA CÁMARA DE DIPUTADOS, 2015-2018

\begin{tabular}{|l|c|c|c|c|c|c|c|c|c|c|c|c|}
\hline $\begin{array}{c}\text { Grupo } \\
\text { Parlamentario }\end{array}$ & Ordinaria & $\%$ & Especial & $\%$ & Bicameral & $\%$ & Investigación & $\%$ & Comité & $\%$ & Total & $\%$ \\
\hline PRI & 23 & 41.1 & 0 & 0 & 0 & 0 & 0 & 0 & 2 & 100 & 25 & 41.7 \\
\hline PAN & 12 & 21.4 & 1 & 100 & 0 & 0 & 0 & 0 & 0 & 0 & 13 & 21.7 \\
\hline PRD & 7 & 12.5 & 0 & 0 & 0 & 0 & 0 & 0 & 0 & 0 & 7 & 11.7 \\
\hline PVEM & 5 & 8.9 & 0 & 0 & 1 & 100 & 0 & 0 & 0 & 0 & 6 & 10 \\
\hline MORENA & 4 & 7.1 & 0 & 0 & 0 & 0 & 0 & 0 & 0 & 0 & 4 & 6.7 \\
\hline MC & 3 & 5.4 & 0 & 0 & 0 & 0 & 0 & 0 & 0 & 0 & 3 & 5 \\
\hline NA & 1 & 1.8 & 0 & 0 & 0 & 0 & 0 & 0 & 0 & 0 & 1 & 1.7 \\
\hline
\end{tabular}

Fuente: Distribución de Presidencias por Grupo Parlamentario. Comisión y Comités LXIII Legislatura. Disponible en: http://sitl.diputados.gob.mx/LXIII_leg/cuadro_presidenciaslxiii.php>.

De igual modo se encuentra la siguiente distribución actualizada de Diputadas que presiden las siguientes comisiones:

Cuadro 11

COMISIONES ORDINARIAS PRESIDIDAS POR MUJERES

LXIII LEGISLATURA DE LA CÁMARA DE DIPUTADOS, 2015-2018

\begin{tabular}{|c|c|c|c|c|c|}
\hline Comisión & Nombre Presidenta & Partido & $\begin{array}{l}\text { Tipo de } \\
\text { elección }\end{array}$ & Suplente & Entidad \\
\hline Cambio Climático & $\begin{array}{l}\text { María de los Ángeles } \\
\text { Rodríguez Aguirre }\end{array}$ & PAN & MR & $\begin{array}{c}\text { Rocío Leticia Zavala } \\
\text { García }\end{array}$ & $\begin{array}{l}\text { San Luis } \\
\text { Potosí }\end{array}$ \\
\hline Comunicaciones & $\begin{array}{c}\text { Ivonne Aracelly Ortega } \\
\text { Pacheco }\end{array}$ & PRI & $\mathrm{RP}$ & $\begin{array}{l}\text { Zacil Leonor Moguel } \\
\text { Manzur }\end{array}$ & Yucatán \\
\hline Distrito Federal & $\begin{array}{c}\text { Cecilia Guadalupe Soto } \\
\text { González }\end{array}$ & PRD & $\mathrm{RP}$ & $\begin{array}{c}\text { María Cristina Teresa } \\
\text { García Bravo }\end{array}$ & $\begin{array}{l}\text { Distrito } \\
\text { Federal }\end{array}$ \\
\hline $\begin{array}{l}\text { Educación Pública y } \\
\text { Servicios Educativos }\end{array}$ & $\begin{array}{c}\text { Hortensia Aragón } \\
\text { Castillo }\end{array}$ & PRD & $\mathrm{RP}$ & $\begin{array}{c}\text { María Guadalupe Aragón } \\
\text { Castillo }\end{array}$ & Chihuahua \\
\hline Energía & $\begin{array}{c}\text { Georgina Trujillo } \\
\text { Zentella }\end{array}$ & PRI & $\mathrm{RP}$ & Joaquina Viveros Córdoba & Tabasco \\
\hline $\begin{array}{l}\text { Fomento Cooperativo y } \\
\text { Economía Social }\end{array}$ & $\begin{array}{c}\text { Norma Xochitl } \\
\text { Hernández Colín }\end{array}$ & MORENA & MR & $\begin{array}{c}\text { Araceli Berenice } \\
\text { Hernández Calderón }\end{array}$ & $\begin{array}{l}\text { Distrito } \\
\text { Federal }\end{array}$ \\
\hline Gobernación & $\begin{array}{l}\text { Mercedes Del Carmen } \\
\text { Guillén Vicente }\end{array}$ & PRI & MR & $\begin{array}{c}\text { Elsa María Tamayo } \\
\text { Cárdenas }\end{array}$ & Tamaulipas \\
\hline
\end{tabular}




\begin{tabular}{|c|c|c|c|c|c|}
\hline Comisión & Nombre Presidenta & Partido & $\begin{array}{l}\text { Tipo de } \\
\text { elección }\end{array}$ & Suplente & Entidad \\
\hline $\begin{array}{l}\text { Hacienda y Crédito } \\
\text { Pública }\end{array}$ & $\begin{array}{c}\text { Gina Andrea Cruz } \\
\text { Blackledge (Licencia) }\end{array}$ & PAN & $\mathrm{RP}$ & María Olivia Picazo Olmos & $\begin{array}{c}\text { Baja } \\
\text { California }\end{array}$ \\
\hline Igualdad de Género & $\begin{array}{c}\text { Laura Nereida Plascencia } \\
\text { Pacheco }\end{array}$ & PRI & MR & $\begin{array}{c}\text { Sandra Pompeya Aceves } \\
\text { Tejeda }\end{array}$ & Jalisco \\
\hline Jurisdiccional & $\begin{array}{l}\text { Sandra Méndez } \\
\text { Hernández }\end{array}$ & PRI & MR & $\begin{array}{c}\text { Mariana Vanessa Ruíz } \\
\text { Ledesma }\end{array}$ & $\begin{array}{l}\text { Estado de } \\
\text { México }\end{array}$ \\
\hline Juventud & $\begin{array}{c}\text { Karla Karina Osuna } \\
\text { Carranco }\end{array}$ & PAN & $\mathrm{RP}$ & $\begin{array}{c}\text { Úrsula Cariño Estrada } \\
\text { Lomelí }\end{array}$ & Coahuila \\
\hline Protección Civil & $\begin{array}{c}\text { María Elena Orantes } \\
\text { López }\end{array}$ & $\begin{array}{l}\text { Movimiento } \\
\text { Ciudadano }\end{array}$ & $\mathrm{RP}$ & $\begin{array}{c}\text { Dalia María Rocha Ladrón } \\
\text { de Guevara }\end{array}$ & Chiapas \\
\hline Radio y Televisión & Lia Limón García & PVEM & $\mathrm{RP}$ & $\begin{array}{l}\text { Verónica Guadalupe Brunt } \\
\text { González }\end{array}$ & $\begin{array}{l}\text { Distrito } \\
\text { Federal }\end{array}$ \\
\hline Seguridad Social & Araceli Damián González & MORENA & MR & $\begin{array}{c}\text { María del Rosario Palacios } \\
\text { Alejo }\end{array}$ & $\begin{array}{l}\text { Distrito } \\
\text { Federal }\end{array}$ \\
\hline $\begin{array}{l}\text { Trabajo y Previsión } \\
\text { Social }\end{array}$ & $\begin{array}{c}\text { Ana Georgina Zapata } \\
\text { Lucero }\end{array}$ & PRI & MR & $\begin{array}{c}\text { Gloria Viviana Juárez } \\
\text { Fierro }\end{array}$ & Chihuahua \\
\hline Turismo & Gretel Culin Jaime & PAN & $\mathrm{RP}$ & $\begin{array}{c}\text { Mine Valeria Mares } \\
\text { Villaseñor }\end{array}$ & Colima \\
\hline Vivienda & $\begin{array}{c}\text { Alma Carolina Viggiano } \\
\text { Austria }\end{array}$ & PRI & MR & $\begin{array}{c}\text { Brenda Lizette Flores } \\
\text { Franco }\end{array}$ & Hidalgo \\
\hline
\end{tabular}

Fuente: Elaboración propia con datos del Listado de Comisiones Ordinarias, LXIII Legislatura de la Cámara de Diputados. Disponible en: <http://sitl.diputados.gob.mx/LXIII_leg/listado_de_comisioneslxiii.php?tct=l>.

De las 56 Comisiones Ordinarias de la LXIII Legislatura de la Cámara de Diputados 17, correspondiente al 30.36\%, están presididas actualmente por mujeres, de las cuales 7 militan en el PRI y una en el PVEM; las restantes las presiden mujeres de las bancadas correspondientes al PAN, PRD, Movimiento Ciudadano Y MORENA.

Por lo que corresponde a la LXII-LXIII del Senado de la República. 
Cuadro 12

COMISIONES ORDINARIAS PRESIDIDAS POR MUJERES

LXII Y LXIII LEGISLATURA DEL SENADO DE LA REPÚBLICA, 2012-2018

\begin{tabular}{|c|c|c|c|c|c|}
\hline Comisión & Nombre Presidenta & Partido & $\begin{array}{l}\text { Tipo de } \\
\text { elección }\end{array}$ & Suplente & Entidad \\
\hline $\begin{array}{l}\text { Comisión de Asuntos } \\
\text { Migratorios }\end{array}$ & $\begin{array}{c}\text { Layda Sansores San } \\
\text { Román }\end{array}$ & PT & $\mathrm{RP}$ & $\begin{array}{c}\text { María del Carmen } \\
\text { Ojesto Martínez } \\
\text { Porcayo }\end{array}$ & Lista Nacional \\
\hline $\begin{array}{l}\text { Comisión de Atención De } \\
\text { Grupos Vulnerables }\end{array}$ & $\begin{array}{l}\text { Lilia Guadalupe Merodio } \\
\text { Reza }\end{array}$ & PRI & MR & Adriana Terrazas Porras & Chihuahua \\
\hline $\begin{array}{l}\text { Comisión Contra la Trata de } \\
\text { Personas }\end{array}$ & $\begin{array}{l}\text { Adriana Dávila Fernández } \\
\text { (Licencia a partir del } 26 \\
\text { de febrero 2016) }\end{array}$ & PAN & $\begin{array}{l}\text { PM (Primera } \\
\text { Minoría) }\end{array}$ & Amelia Torres López & Tlaxcala \\
\hline Comisión de Cultura & $\begin{array}{l}\text { Blanca María del Socorro } \\
\text { Alcalá Ruiz } \\
\text { (Licencia a partir del } 18 \\
\text { de febrero 2016) }\end{array}$ & PRI & MR & $\begin{array}{l}\text { María del Carmen } \\
\text { Izaguirre Francos }\end{array}$ & Puebla \\
\hline $\begin{array}{l}\text { Comisión de los Derechos } \\
\text { de la Niñez y de la } \\
\text { Adolescencia }\end{array}$ & $\begin{array}{c}\text { Martha Elena García } \\
\text { Gómez }\end{array}$ & PAN & $\begin{array}{l}\text { PM (Primera } \\
\text { Minoría) }\end{array}$ & $\begin{array}{c}\text { Ángela Esmeralda Ortiz } \\
\text { Urciaga }\end{array}$ & Nayarit \\
\hline $\begin{array}{l}\text { Comisión de Derechos } \\
\text { Humanos }\end{array}$ & $\begin{array}{l}\text { Angélica De la Peña } \\
\text { Gómez }\end{array}$ & PRD & $\mathrm{RP}$ & $\begin{array}{c}\text { Adriana Noemí Ortíz } \\
\text { Ortega }\end{array}$ & Lista Nacional \\
\hline $\begin{array}{l}\text { Comisión de Desarrollo } \\
\text { Social }\end{array}$ & $\begin{array}{l}\text { Iris Vianey Mendoza } \\
\text { Mendoza }\end{array}$ & PRD & $\mathrm{RP}$ & Olivia Corral Arriaga & Lista Nacional \\
\hline $\begin{array}{l}\text { Comisión de Estudios } \\
\text { Legislativos }\end{array}$ & Graciela Ortiz González & PRI & $\mathrm{RP}$ & $\begin{array}{c}\text { Ana Georgina Zapata } \\
\text { Lucero }\end{array}$ & Lista Nacional \\
\hline $\begin{array}{l}\text { Comisión Para la Familia y } \\
\text { Desarrollo Humano }\end{array}$ & $\begin{array}{l}\text { Lisbeth Hernández } \\
\text { Lecona }\end{array}$ & PRI & $\begin{array}{l}\text { PM (Primera } \\
\text { Minoría) }\end{array}$ & $\begin{array}{c}\text { Cecilia Verónica López } \\
\text { González } \\
\text { (MR) }\end{array}$ & Morelos \\
\hline Comisión de Gobernación & $\begin{array}{l}\text { María Cristina Díaz } \\
\text { Salazar }\end{array}$ & PRI & $\mathrm{RP}$ & $\begin{array}{l}\text { María Esther Terán } \\
\text { Velázquez }\end{array}$ & Lista Nacional \\
\hline $\begin{array}{l}\text { Comisión de Medio } \\
\text { Ambiente y Recursos } \\
\text { Naturales }\end{array}$ & Ninfa Salinas Sada & PVEM & $\mathrm{RP}$ & $\begin{array}{c}\text { Alma Lucía Arzaluz } \\
\text { Alonso }\end{array}$ & Lista Nacional \\
\hline $\begin{array}{l}\text { Comisión para la Igualdad } \\
\text { de Género }\end{array}$ & $\begin{array}{c}\text { Diva Hadamira Gastélum } \\
\text { Bajo }\end{array}$ & PRI & $\mathrm{RP}$ & $\begin{array}{l}\text { Ofelia Socorro Jasso } \\
\text { Nieto }\end{array}$ & Lista Nacional \\
\hline
\end{tabular}




\begin{tabular}{|c|c|c|c|c|c|}
\hline Comisión & Nombre Presidenta & Partido & $\begin{array}{l}\text { Tipo de } \\
\text { elección }\end{array}$ & Suplente & Entidad \\
\hline $\begin{array}{l}\text { Comisión de Protección } \\
\text { Civil }\end{array}$ & $\begin{array}{l}\text { Angélica del Rosario } \\
\text { Araujo Lara }\end{array}$ & PRI & MR & $\begin{array}{c}\text { Alaine Patricia López } \\
\text { Briceño }\end{array}$ & Yucatán \\
\hline $\begin{array}{l}\text { Comisión de Radio, } \\
\text { Televisión y Cinematografía }\end{array}$ & $\begin{array}{l}\text { María Alejandra Barrales } \\
\text { Magdaleno (Licencia } 16 \\
\text { de julio 2015) }\end{array}$ & PRD & MR & $\begin{array}{c}\text { Martha Angélica Tagle } \\
\text { Martínez }\end{array}$ & $\begin{array}{l}\text { Distrito } \\
\text { Federal }\end{array}$ \\
\hline $\begin{array}{l}\text { Comisión de Reforma } \\
\text { Agraria }\end{array}$ & $\begin{array}{l}\text { Luisa María Calderón } \\
\text { Hinojosa }\end{array}$ & PAN & $\mathrm{RP}$ & Lizette Clavel Sánchez & Lista Nacional \\
\hline $\begin{array}{l}\text { Comisión de Relaciones } \\
\text { Exteriores }\end{array}$ & Gabriela Cuevas Barrón & PAN & $\mathrm{RP}$ & $\begin{array}{c}\text { Blanca Belia Márquez } \\
\text { Espinoza }\end{array}$ & Lista Nacional \\
\hline $\begin{array}{l}\text { Comisión de Relaciones } \\
\text { Exteriores África }\end{array}$ & Margarita Flores Sánchez & PRI & MR & $\begin{array}{l}\text { Michelle Arandine } \\
\text { Barrón Vivanco }\end{array}$ & Nayarit \\
\hline $\begin{array}{l}\text { Comisión de Relaciones } \\
\text { Exteriores, América del } \\
\text { Norte }\end{array}$ & Marcela Guerra Castillo & PRI & MR & $\begin{array}{c}\text { Eva Patricia Salazar } \\
\text { Marroquín }\end{array}$ & Nuevo León \\
\hline $\begin{array}{l}\text { Comisión de Relaciones } \\
\text { Exteriores América Latina y } \\
\text { el Caribe }\end{array}$ & $\begin{array}{l}\text { Mariana Gómez del } \\
\text { Campo Gurza }\end{array}$ & PAN & $\mathrm{RP}$ & $\begin{array}{l}\text { María Isabel Quiroga } \\
\text { Fernández }\end{array}$ & Lista Nacional \\
\hline $\begin{array}{l}\text { Comisión de Relaciones } \\
\text { Exteriores Organismos } \\
\text { Internacionales }\end{array}$ & $\begin{array}{l}\text { Laura Angélica Rojas } \\
\text { Hernández }\end{array}$ & PAN & $\mathrm{RP}$ & Adriana Cortés Álvarez & Lista Nacional \\
\hline $\begin{array}{l}\text { Comisión de Relaciones } \\
\text { Exteriores, Organismos No } \\
\text { Gubernamentales }\end{array}$ & $\begin{array}{l}\text { María Lucero Saldaña } \\
\text { Pérez }\end{array}$ & PRI & MR & $\begin{array}{l}\text { Minerva Ronquillo } \\
\text { Onofre }\end{array}$ & Puebla \\
\hline Comisión de Salud & $\begin{array}{c}\text { Maki Esther Ortiz } \\
\text { Domínguez } \\
\text { (Licencia a partir del } 4 \text { de } \\
\text { febrero 2016) }\end{array}$ & PAN & MR & Andrea García García & Tamaulipas \\
\hline Comisión de Vivienda & María Elena Barrera Tapia & PVEM & MR & $\begin{array}{l}\text { Martha Vianey Luque } \\
\text { Inzunza }\end{array}$ & $\begin{array}{l}\text { Estado de } \\
\text { México }\end{array}$ \\
\hline
\end{tabular}

Fuente: Elaboración propia con datos de Listado de Comisiones Ordinarias, LXIII Legislatura del Senado de la República. Disponible en: <http://www.senado.gob.mx/index.php?ver=int\&mn=3\&sm=l > y <http://www.senado.gob.mx/index. php? ver=int\&mn=3\&sm=6>.

De las 64 Comisiones Ordinarias que integran el Senado de la República, actualmente 23 están presididas por mujeres, es decir el 35.94 por ciento de la participación de las mujeres en la Cámara Alta se ubican a la cabeza de las comisiones, sumado a ello sus respectivas suplentes; 10 comisiones encabezadas 
por mujeres son militantes del PRI y 2 del PVEM. Podríamos decir que 12 de 23 comisiones del Senado presididas por mujeres manifestarían una expresión favorable a las iniciativas presentadas por el Ejecutivo Federal en el Senado para discutirlas al interior de cada comisión. Es importante tener presenta que tres Senadoras solicitaron licencia por tiempo indefinido PRD, PAN y PRI, respectivamente.

Llama la atención que de este cuadro 11 Senadoras responden al tipo de elección por Representación Proporcional, 9 de Mayoría Relativa y 3 de Primera Minoría. Estaríamos aludiendo que en su mayoría las Senadoras ingresan a la Cámara Alta por la propia designación a la cual tiene derecho cada partido político. Dato sin duda significativo para futuros análisis.

Con esta actual composición de mujeres legisladoras en ambas Cámaras, podemos decir que se cuenta con logros sustantivos en materia de igualdad de género en el ámbito electoral y de participación parlamentaria. Los mecanismos normativos para elevar de un 40 a un $50 \%$ en un plazo tan corto hablan de un compromiso estatal por atender y favorecer condiciones de igualdad a las mujeres en el terreno del Poder Legislativo a nivel Federal, así como en el orden estatal y municipal. Sin embargo, las mejoras sustantivas en el resto de los rubros económico, laboral, educativo, social e incluso en el seno familiar, aún no logran alcanzar mínimos de equidad. Esperaríamos que las proporciones con las cuales se han beneficiado y favorecido la presencia de mujeres en el Congreso Mexicano redunde en reglamentaciones efectivas y en implementaciones de políticas públicas de largo alcance para revertir los rezagos que persisten en la materia, supondríamos que tanto el Ejecutivo como el Poder Legislativo encabezado por un porcentaje más representativo de mujeres, mantuviera una sinergia para que ambos poderes presenten y discutan iniciativas en pro de ello, no solo con las mujeres afines al Ejecutivo o en alianza con el mismo, sino que en un concierto que permita retomar de las diversas voces de las legisladoras elementos sustantivos de mejora que se vean reflejados a corto plazo para dar cuenta de ello.

\section{Reflexiones finales}

La condición de paridad de género en los procesos de elección de candidatos en los tres órdenes de gobierno en México dejó de ser una aspiración y se ha convertido en una realidad contundente en el actual Sistema Político Mexicano. 
Esta nueva condición que adquieren los procesos políticos electorales donde se promueve y garantiza el 50 por ciento para mujeres y hombres en la incorporación a las candidaturas para ocupar cargos de elección popular, transformó en muy poco tiempo la percepción negativa asociada a los procesos de democratización política en el marco de la Reforma del Estado, un Estado mexicano que paulatinamente vía las modificaciones normativas y constitucionales ha transitado a etapas de mayor y comprometida apertura política. Desde mediados de los años 90 del siglo pasado la preocupación por revertir los nulos esfuerzos en pos de incorporar a un mayor número de mujeres en los cargos de elección pública, empezó a ser mayor, en especial una vez consumado el proceso electoral del año 2000 con el cambio de régimen y la alternancia política. Podemos decir que los procesos de liberalización y democratización dieron sus primeros frutos con el cambio del milenio. Sin duda la democracia en su sentido amplio debe atender y responder a las necesidades de todos, hombres y mujeres, para que sean beneficiarios de los valores democráticos alusivos a la libertad, la justicia y la igualdad. Este último, encaminado a marcar pautas que equilibren derechos y que éstos sean otorgados en las mismas condiciones para todos los ciudadanos.

Es pues con ello que la normativa en materia de género cobró relevancia para favorecer a las mujeres en México y que se promovieron las leyes para prevenir y eliminar la discriminación; para erradicar la violencia y para lograr la igualdad entre hombres y mujeres. Todo ello con miras a dar cumplimiento a los dictados de los organismos internacionales como la ONU y los acuerdos de la CEDAW 1979 y Beijing 1995, como factores en buena medida detonantes y vigilantes de las leyes para proteger y dar contención a las mujeres. Los gobiernos del nuevo milenio, también se encargaron de arropar institucionalmente con planes y programas el cumplimiento de las leyes, de ahí el surgimiento de INMUJERES en 2001 y su encomienda de implementar las acciones de gobierno y políticas públicas para atender y paulatinamente resolver la complejidad ancestral y culturalmente enraizada, asociada a la discriminación y violencia que padecen las mujeres en México.

Los programas de gobierno como PROIGUALDAD en su momento y el actual Programa Nacional para la Igualdad de Oportunidades y no Discriminación contra las Mujeres 2013-2018, son reflejo de la preocupación del Estado mexicano por atender la problemática en un esquema de derechos amplio. Sin duda, el tema de la paridad de género en los Congresos locales y en particular en el Congreso Federal también recupera importancia y se han podido apreciar los cambios 
normativos constitucionales, reglamentarios y en códigos electorales para otorgarla. Así, a partir de 1996 la preocupación por integrar la paridad de género en materia electoral fue incrementándose hasta lograr en 2014 la modificación constitucional para otorgar paridad de género en las elecciones presentes y futuras, lo que da cuenta de consolidación del Estado democrático en México.

Los resultados de las elecciones y los cambios en la conformación del Congreso Mexicano son más representativos en las legislaturas actuales, ya que, si vemos, entre la LVI legislatura, 1994-1997, de la Cámara de Diputados donde se contabilizaron 72 mujeres y en la actual LXIII legislatura, 2015-2018, de la misma, ahora tenemos 212, el incremento es más que significativo. Lo mismo ocurre con el Senado de la República, ya que en la LVI legislatura de 1994 encontramos solo 13 mujeres y en la actual ya contabilizamos 42. A ello se suman los espacios que están asumiendo las legisladoras al interior de las Cámaras, en particular, al ocupar presidencias en las Comisiones internas de la Cámara de Diputados y el Senado, ya hablamos de su incorporación en Comisiones con mayor peso político como la actual Comisión de Gobernación de la Cámara de Diputados presidida por una mujer, o bien, la de Hacienda y Crédito Público, la de Comunicaciones, la de Radio y Televisión y, sin duda, la de Igualdad de Género y otras tantas, esbozadas en este trabajo, ocupadas en su presidencia por mujeres. Sumado a ello, el grupo parlamentario al que pertenecen y la incidencia política que pueden y logran tener al interior de sus comisiones y de sus grupos políticos, así como el impacto que pudieran tener las iniciativas presidenciales al interior del Congreso con una mayor presencia de estas mujeres legisladoras.

Podemos cerrar diciendo que llegar a la paridad por la vía rápida, como se ha expuesto, ha sido un acierto de la Reforma Política en materia electoral y de género para el actual gobierno, se alcanza finalmente condiciones de igualdad en este rubro y se coloca al país a la par de los más avanzados en la región y, sin duda, a nivel internacional. El punto será ahora que este avance sustancial en poco tiempo logrado, también pueda replicarse en la emisión de normas y de políticas públicas generosas puestas en la agenda de gobierno para salvaguardar a las mujeres de situaciones lamentables que aún padecen en el espacio privado y público, en todos los rubros, incluso en materia de violencia política de género. Que no sea pues este importante avance sólo un recurso político ajeno a las realidades y carencias que sufren el grueso de las mujeres en el México actual, recordemos que ocupan más del $50 \%$ de la población en el territorio nacional y que nuestras legisladoras, sensibles a ello, hagan valer su condición de género y, sin duda, su posición de poder en el actual Sistema Político Mexicano. 


\section{Fuentes}

Alarcón Olguín, Víctor, "La equidad de género en el ámbito electoral mexicano", en Ochoa Reza, Enrique (coord.), Equidad de género y derecho electoral en México, México, Tribunal Electoral del Poder Judicial de la Federación, 2009.

Cámara de Diputados, "Álbum de Diputados Federales 2015-2018". Disponible en: <http://sitl.diputados.gob.mx/LxiI_leg/album_foto_tc.pdf>.

Cámara de Diputados, "Integración por género y Grupo Parlamentario". Disponible en: <www.diputados.gob.mx>.

Cámara de Diputados, Ley General de Instituciones y Procedimientos Electorales. Nueva Ley publicada en el Diario Oficial de la Federación el 23 de mayo de 2014. Declaratoria de invalidez de artículos por Sentencia de la SCJN notificada para efectos legales 10-09-2014 y publicada en el DOF 13-08-2015, p. 104. Disponible en: <http:// www.diputados.gob.mx/LeyesBiblio/pdf/LGIPE_130815.pdf>.

Cámara de Diputados, Ley General de Partidos Políticos, Nueva Ley publicada en el Diario Oficial de la Federación el 23 de mayo de 2014. Declaratoria de invalidez de artículos por Sentencia de la SCJN notificada para efectos legales 10-09-2014 y publicada en el DOF 13-08-2015., p. 5. Disponible en: <http://www.diputados.gob. mx/LeyesBiblio/pdf/LGPP_130815.pdf>.

Diario Oficial de la Federación, Decreto por el que se aprueba el Programa Nacional para la Igualdad de Oportunidades y no Discriminación contra las Mujeres 2013-2018, México, 30 de agosto de 2013. Disponible en: <http://www.dof.gob.mx/nota_detalle. php?codigo $=5312417 \& f e c h a=30 / 08 / 2013>$.

Diario Oficial de la Federación, Ley General para la Igualdad entre Mujeres y Hombres, México, 2 de agosto de 2006. Disponible en: <http://www.diputados.gob.mx/LeyesBiblio/pdf/LGIMH_040615.pdf>.

Diario Oficial de la Federación, Programa Nacional para la Igualdad de Oportunidades y no Discriminación contra las Mujeres 2013-2018. PROIGUALDAD 2013-2018, México, 30 de agosto de 2013.

Fredenvall, Lenita, "Cuotas de género en materia electoral como vía rápida a la paridad", En Fredenvall, Lenita et al., Cuotas de género. Visión comparada, México, Tribunal Electoral del Poder Judicial de la Federación, 2013.

Gilas, Karolina Monika, "Hacia una nueva época. Paridad de género en la reforma electoral 2014", en González Madrid, Miguel y Escamilla Cadena, Alberto (coords.), El nuevo Sistema Político Electoral Mexicano en 2015, México, Universidad Autónoma Metropolitana, Iztapalapa, 2015, pp. 190-192.

Gobierno de la República, Plan Nacional de Desarrollo 2013-2018, México, 2013. Disponible en: <http://pnd.gob.mx/wp-content/uploads/2013/05/PND.pdf>.

Gobierno de los Estados Unidos Mexicanos, Plan Nacional de Desarrollo 2001-2006, México, 2001, pp. 83-84, Disponible en: <http://bibliotecadigital.conevyt.org.mx/ colecciones/conevyt/plan_desarrollo.pdf> 
Gobierno de los Estados Unidos Mexicanos, Plan Nacional de Desarrollo 2007-2012, México, 2007, pp. 210-211. Disponible: <http://pnd.calderon.presidencia.gob.mx/ pdf/PND _2007-2012.pdf>

INMUJERES, Observatorio de la participación política de las mujeres en México. México. Disponible en: <http://www.gob.mx/inmujeres/acciones-y-programas/observatoriode-participacion-politica-de-las-mujeres-en-mexico-21620? idiom=es-MX>.

Instituto Nacional de las Mujeres, Programa Nacional para la Igualdad entre Mujeres y Hombres 2008-2012, México, 2008. Disponible en: <http://www.hacienda.gob.mx/ LASHCP/equidad/marco_legal/100919.pdf>.

Meyer-Serra, Carlos Elizondo y Nacif Hernández, Benito, "La lógica del cambio político en México" en Meyer-Serra, Carlos Elizondo y Nacif Hernández, Benito (comps.), Lecturas sobre el cambio político en México, México, CIDE-FCE, 2002.

O'Donnell, Guillermo y Schmitter, Philipe C., Transitions from Authoritarian Rule. Tentative Conclusions

Organización de las Naciones Unidas, Objetivos para el Milenio. Informe de 2013. Disponible en: <http://www.un.org/es/millenniumgoals/pdf/mdg-report-2013-spanish.pdf>.

Organización de las Naciones Unidas, Objetivos para el Milenio. Informe de 2015. Disponible en: <http://www.un.org/es/millenniumgoals/pdf/2015/mdg-report-2015_spanish.pdf>.

Peschard, Jacqueline, "Estudio de caso, El sistema de cuotas en América Latina. Panorama general", en IDEA Internacional, Mujeres en el Parlamento. Más allá de los números, Suecia, 2012.

Presidencia de la República, Sexto Informe de Gobierno, 2012. Anexo Estadístico. II. Estadísticas Nacionales. Igualdad de Oportunidades

Presidencia de la República, Tercer Informe de Gobierno, 2003. Anexo Estadístico.

Secretaría de Gobernación, "Sistema de Información Legislativa". Disponible en: <http:// sil.gobernacion.gob.mx/portal>.

Sosa, Miguel, "México se merece más respeto a sus instituciones, a sus diputadas electas, a sus mujeres y a sus votantes", El Universal, México, 8 de marzo de 2010. Disponible en: <http://archivo.eluniversal.com.mx/notas/664275.html>.

Sosa, Miguel, "ONu Critica caso de diputadas Juanitas", El Universal, México, 8 de marzo de 2010. Disponible en: <http://archivo.eluniversal.com.mx/notas/664275.html>. 


\title{
EL CÍCLOPE PRESIDENTE DE LA DESCOMPOSICIÓN COLECTIVA
}

\author{
Julio Bracho Carpizo
}

$\mathrm{L}$

a reforma política en México que se genera y dirige por Jesús Reyes Heroles, durante el régimen de José López Portillo, se elabora como una respuesta al callejón sin salida que había conducido la crisis política tanto de la represión del movimiento estudiantil de 1968 como a los intentos guerrilleros que procuraban instaurar la lucha armada como cambio de un Estado cada ves más tiránico y controlador. La antecedente apertura política que planteó Luis Echeverría Álvarez fue más de concesiones sociales que de cauces a la participación política institucional. Se formuló una nueva reforma agraria que podía incluso tender a la formación de ejidos colectivos, se permitió cierta efervescencia en el movimiento obrero, de electricistas, trabajadores universitarios, tabacaleros, diferentes empresas privadas como lo fue Spicer; pero también se confrontó el régimen con formaciones guerrilleras que exacerbaron la visión tiránica sobre el régimen e, inclusive, llevaron a la extensión de una guerra sucia para eliminarlas.

La reforma política buscó recuperar el prestigio perdido de un régimen presidencialista que vislumbraba en la participación política electoral, los cauces para volver a legitimar las instituciones políticas, principalmente de lado de la izquierda más radical que podía ser representada, incluso, por el Partido Comunista. Ya que partidos como el Popular Socialista, dirigido por la izquierda oficial encarnada por Lombardo Toledano, o el Partido de Acción Nacional con un perfil democrático conservador, no dejaban de ser vistos como parte instituida de la coreografía del institucional imperio presidencial, donde el Partido Revolucionario Institucional funcionaba más como agencia de colocaciones políticas que como una organización autónoma del poder estatal, y, 
mucho menos, como a la usanza de los regímenes totalitarios, donde el partido reinante podía someter bajo su égida al conjunto del Estado, establecer la eterna tiranía de su Secretario General o de su Führer. Eran las reglas del Estado no las del partido las que prioritariamente se cumplían, y, en este caso, la regla de oro revolucionaria: la no reelección. La que indiscutiblemente tuvo que cumplir cada presidente postrevolucionario. Esto dejaba ver lo que constituye el paso esencial para terminar con las formas monárquicas de encarnación del poder: la institución del límite temporal al ejercicio del poder, su veto a la identificación personal más allá de la institución. Aun cuando, esto, ni siquiera los dos recientes presidentes panistas lo han tenido claro en su estrechez política, y se les ha metido en gana, en contra de toda la tradición republicana, impulsar su reelección encarnada en su mujer: ¿no considera su tradición cristiana a la mujer de un hombre parte de su carne, por no mencionar su costilla? No hay forma más exacerbada de nepotismo que esta, la que debería de estar expresamente penada por la ley.

Pero esta caducidad del ejercicio del poder tiene otras virtudes. Si la presidencia no podía llegar a ser totalmente tiránica porque el mismo relevo del poder le propina un freno, también no lo es porque le daba una dinámica específica al uso y dinámica del poder que llegaba también a caracterizarlo en sus propias motivaciones para decidir, entre otras cosas, su gabinete. Los secretarios de Estado competían necesariamente por la sucesión presidencial, generalmente con el mejor ejercicio de sus funciones como su mejor carta para el cargo. Además, los secretarios, posibles sucesores, llegaban a sus respectivos puestos por una selección presidencial que lograba buenos márgenes de libertad respecto a su antecesor y que, en muchos casos, correspondía a cualidades reconocidas social y profesionalmente, más que a la pertenencia a una burocracia partidaria escalafonaria, a una gerontocracia en el poder o a una mafia sectaria con intereses anquilosados que podrían ser las típicas consecuencias en otros regímenes de orígenes revolucionarios. El estilo personal de gobernar, como lo veía Daniel Cosío Villegas, tenía sus bemoles y sus virtudes, pero esto no deja de ser cierto también para todos los ejercicios y regímenes de poder en la historia. La personalidad tiene un peso en el poder: este la amplía en todos sus rasgos. No deja de ser lo mejor de las instituciones promover las virtudes y delimitar las lacras nefastas de los personajes en el poder. La presidencia de México no fue imperial. A ningún presidente en México se le ha ocurrido conquistar siquiera Belice o Guatemala, y en el ejercicio del poder interno, en los últimos gobiernos gracias al marco institucional, tampoco hemos tenido la 
desgracia de llegar a la mera tiranía, sí es que por ese mote imperial se quiere denotar el ejercicio del poder absoluto.

A partir de la presidencia de Miguel de la Madrid se procedió a abrir las fronteras al comercio internacional para supuestamente intentar pagar la crecida deuda externa, a partir del sometimiento a las reglas impuestas por los acreedores de fondos, cuyos intereses subieron a discreción de los mismos prestamistas ligados a los dictámenes políticos imperiales de la Reserva Federal Estadounidense. En ese derrotero, la política económica estatal mexicana se vio impelida a instrumentar todas y cada una de las medidas que pedía el capital extranjero para instalarse y consolidar su predominio en el territorio nacional. Lograr la autonomía del Banco de México no fue más que una reducción del poder presidencial para intervenir en el ámbito prioritario para el control de la política macroeconómica, para dejarlo en manos de "especialistas" representantes de los intereses bancarios trasnacionales. Justo como si la política y la economía no tuvieran nada que ver.

\section{Dispersar el corporativismo}

Dada a minimizar al Estado, para reducir su poder centralizado en la figura presidencial, para llevar la intervención del Estado en la sociedad a su mínima expresión, parecería esta política más una propia del comunismo planteado en su etapa final de desarrollo o, inclusive, del anarquismo que pugna por disolver todo tipo de poder. Pero esta consigna por reducir el Estado del llamado neoliberalismo, no deja de ser un llamado para disolver cierto intereses políticos y evitar que se expresen como alternativas estatales con posibilidad de instrumentarse a través del poder del Estado, que ahora generalizan, a falta de mote, como populistas. En el fondo, la actual política neoliberal mercantilista sí pugna por el fortalecimiento de un poder estatal para llevarlo hasta sus últimas consecuencias: este es el estado policiaco y represor de todo los intereses populares, todos los que puedan oponerse a la instrumentación del capital para apropiarse de cuantos bienes naturales le sean necesarios para el desarrollo de sus procesos productivos en vías de su valoración, y, por supuesto, para someter, llegado el caso, a los trabajadores que no quieran subordinarse a las reglas, a las condiciones laborales y a los salarios tan bajos como le sea posible al capital imponer, sin dejar de recurrir a formas represivas. Un Estado represor que inclusive pueda reducir las condiciones contractuales ganadas por 
anteriores leyes o pactos negociados en condiciones más favorables ante los patronos. Un Estado que puede imponer mayores trabas a la asociación libre e inteligente de los trabajadores como para vetar su capacidad de demanda, de mejora de sus condiciones laborales. Un Estado en suma retrógrado que permita el sometimiento de las libertades asociativas y contractuales de los trabajadores, que reduzca el gasto social en educación, en salud, en cultura, en ciencia. Quien al reprimir la libre manifestación de intereses en el ámbito asociativo laboral, al cargarse más que evidentemente del lado del empresariado o del lado corporativo del sindicalismo, sin procurar profundizar los libres compromisos de las partes tanto para desarrollar los muy distintos factores de la producción, como para pactar mejores formas de distribución de las ganancias globales, al promover la desecación de las relaciones contracturales apropiadas a través de los sindicatos blancos o por la represión de una democracia al interior de los sindicatos obreros, al promover la dislocación y separación del trabajador colectivo en trabajadores manuales e intelectuales de confianza, el Estado lejos de contribuir al funcionamiento libre de la sociedad, reprime la libre determinación de sus intereses tanto en el presente como, todavía más patético, en la visión de futuro que permite darle un sentido creativo y hasta competitivo al desenvolvimiento social.

¿Qué incentivo a la productividad y a la innovación puede haber en un sistema productivo anquilosado por salarios miserables, empresarios apoltronados y cuadros medios apergollados en la estructura polarizada de las empresas. Pareciera un orgullo presentar la falta de huelgas en el ambiente laboral mexicano, como ya lo pueden declarar los informes del INEGI, pero si trasladáramos las condiciones del trabajador mexicanos a cualquiera de los países modernos se tendría una huelga general inmediata. El marco legal que ha propiciado esto también se refleja en el funcionamiento de las Juntas de Conciliación y Arbitraje, en la Comisión Nacional de Salarios Mínimos, en el peso cada vez más decisivo que toma la subcontratación que hace que los trabajadores ya ni siquiera contraten con quien trabajan, y mucho menos que obtengan utilidades de la empresa integral donde realizan sus labores. También se remite ese uso institucional a la promoción de sindicatos patronales o blancos, al apoyo a los sindicatos corporativos por no permitir la libre elección y formación libre de sindicatos e incorporación de trabajadores a voluntad, a partir de su desempeño, de sus resultados, del carácter democrático por la participación misma de los trabajadores. 


\section{Dispersar el poder}

La tarea de desmantelar el presidencialismo no se ha acompañado por crear instituciones que repliquen el poder que en todos los ámbitos podía antaño acumular el Presidente. El empeño por la reducción del Estado también ha sido aquel que ha desarmado muchas tareas públicas y comunitarias que se formulan para tratarse a través de lo político. El trabajo institucional democrático implicaría crear instancias sociales y políticas donde la tradicional capacidad de actuar del Presidente no solamente se reformularía, donde su acción encontrara otro nicho para desarrollarse, para mejorar el ejercicio de ese poder, sino además, precisamente por eso, poder engrandecerlo, ampliarlo, crear más poder al hacerlo presente y visible y actuante frente y por la sociedad política institucionalizada: más poder ejecutivo, pero del bueno.

Es cierto que sí se dejan de enfrentar los problemas sociales desde las instancias pertinentes, estos no solamente no se resuelven por sí solos, sino que se ampliarán y crearán otros por una especie de metástasis. Pero se procura desmantelar el presidencialismo mexicano al mismo tiempo que reducir las funciones del Estado justo en el terreno de lo social, de lo laboral, de lo ecológico, de la educación, de la salud, entre otros de aquellos ámbitos que tradicionalmente se le adjudicaban, y también, y con más ímpetu, en todo aquello que pueda ser visto como negocio privado que va desde la construcción y gestión de infraestructura como son los grandes proyectos hidráulicos, y que para la tradición de Wittfogel podría ser el origen mismo del Estado, ${ }^{1}$ hasta los proyectos carreteros, los aeropuertos, cárceles, aduanas, comunicaciones, correos, teléfonos, etc.

El ánimo demoledor de una visión política y comunitaria que se desentiende de funciones y problemas que por su amplitud, trascendencia o complejidad sólo se pueden realizar o resolver eficientemente con un esfuerzo profundo y un trabajo de altas miras que los particulares no están dispuestos a realizar por falta de fondos, de persistencia o por capacidades acotadas. Esto es, la política como capacidad estratégica para atender los problemas comunitarios a largo plazo también tiene una lógica direccional que construye visiones, conjunta acciones, procura fondos y rendimientos. ¿Qué tanto de esto se desaliña cuando desde el mismo Estado se procura la disolución de estos atributos en el ejecutivo?

\footnotetext{
${ }^{1}$ Ver una crítica al respecto en S.N. Eisenstadt, El estudio del despotismo oriental como sistema de poder total, en Revista de Administración Pública, núm. 45, enero-marzo 1981,pp. 35-47 en http://www. juridicas.unam.mx/publica/librev/rev/rap/cont/45/pr/pr5.pdf
} 


\section{La producción del campo socavada}

Un ámbito privilegiado desde finales de la Revolución Mexicana en la construcción de la imagen presidencial, y todavía más a partir del presidente Cárdenas, fue la Reforma agraria. El reparto agrario se convirtió en piedra de toque del trabajo ejecutivo presidencial para darle un sentido a los demandantes de tierra como el fin prioritario de la Revolución mexicana.

A la par de la tierra y del riego se formuló un sistema bancario para asistir a los agricultores en la producción, así como se instrumentaron formas de acopio y comercialización por parte del Estado, empresas como la de fertilizantes, como los ingenios azucareros, o se llegó a la nacionalización en su conjunto de las agroindustrias productoras del tabaco y se dispersaron créditos refaccionarios o se formaron centros de asistencia e investigación para apuntalar el agro. Fue una estrategia que si bien tenía una coherencia y rindió frutos, tampoco se llegó hasta sus últimas consecuencias para hacer productivo el minifundio y asistir a todos los propietarios de la tierra, asistirlos con la tecnología, con los medíos productivos y con las capacidades humanas indispensables en toda producción moderna, por pequeños que fueran, cuyo mejor ejemplo fueron los campos tabaqueros y hoy pueden ser los invernaderos difundidos por países con muy poca tierra como Holanda.

Si desde de la presidencia de López Portillo se empezó a restringir el reparto agrario, ya para el régimen de Salinas de Gortari, se procedió no solamente a terminar con la Reforma agraria sino a desmantelar todo el aparato estatal de asistencia productiva rural, a procurar la privatización de la tierra en manos de los ejidos y, conforme a su pretensión de instrumentar una vez más el latifundismo exasperado, permitió a las grandes corporaciones de accionistas, inclusive extranjeros, acaparar extensiones de tierras prácticamente sin limite a través de holdings. A la par de esto, con el Tratado de Libre Comercio, creció un floreciente negocio incluso para las nuevas burocracias fue la importación de granos, por supuesto producidos en condiciones naturales y económicas mucho más ventajosas que las de los campesinos mexicanos, como fue el caso emblemático del maíz. No se necesitaba ser augur para predecir la desbandada campesina así el norte en busca de vender a mejor precio su trabajo, -inmeditamente se empezó a levantar la Cortina de Hierro infranqueable a lo largo de la frontera-como tampoco se necesitaba demasiada perspicacia como para prever que para muchas zonas el último cultivo redituable iba a ser la mariguana o, inclusive, como en estos tiempos, la goma de la amapola. Ese papel rector del 
Estado en el campo no solamente quedaba trunco sino que incluso insumos modernos indispensables como la electricidad para los pozos o el diésel para los tractores empezaron a subir de precio fuera del alcance los agricultores comunes y corrientes. Movimientos con nuevas características agruparon a agricultores de diferentes espectros sociales como lo hizo El Barzón. Pero también, como caso paradigmático del recurrir de la burocracia corrupta a la importación para socabar y dejar de impulsar la producción del agro nacional, se dieron nuevos delitos inverosímiles que socabaron la producción interna ligados a las más altas esferas políticas y, por lo tanto, no perseguidos, como lo fue la enorme importación de leche irlandesa contaminada por la radioactividad de la explosión de Chernóbil, que marcó el final de la URSS y el principio del fin del Estado postrevolucionario mexicano. La distribución de decenas de miles de toneladas de leche en polvo contaminada, de cientos de millones de litros de leche entre la población infantil más necesitada, y que multiplicó el incremento en incidencia de cáncer entre niños. Raúl Salinas de Gortari era director en ese entonces de Liconsa, la distribuidora de leche de CONASUPO. Las represalias por las denuncias, típicas del ejercicio del poder sin límites, cayeron sobre el vicealmirante Manuel Rodríguez Gordillo, quien descubrió lo radioactivo de leche que tomaron sus marinos, y que les producía diarrea, y sobre el jefe del laboratorio del reactor de Laguna Verde, Miguel Ángel Valdovinos, quien hizo el primer dictamen. ${ }^{2}$

El desmantelamiento de las posibilidades económicas del campesinado, el florecimiento de plantaciones cuyo valor se dispara para aprovechamiento del narcotráfico, las mafias ligadas al poder que multiplican la capacidad de amedrantamiento y sumisión de los ciudadanos para extorsionarlos, despojarlos de sus bienes y hasta de la vida, son los signos del campo mexicano globalizado. Esto ligado al negocio de abastecimiento de armas -letales para la salud pública e introducidas incluso con el consentimiento de las autoridades de Estados Unidos- torna todavía más explosivo el campo mexicano. Si ni siquiera por motivo de salud pública se persiguieron a los dispensadores de leche radioactiva, tam-

\footnotetext{
${ }^{2}$ Guillermo Zamora, "CONASUPO Leche radiactiva, negligencia sin castigo", Proceso, 26 de abril, 2014, en http://www.proceso.com.mx/370752/leche-radiactiva-la-negligencia-sin-castigo; https:// achtung00.wordpress.com/2011/01/12/la-leche-radioactiva-de-la-conasupo/ Cecilia Mora-Donatto, Treinta años de Investigaciones parlamentarias en México (1977-2007). Qué investigaron los diputados federales?, Instituto de Investigaciones Jurídicas, UnAM, 2013, especialmente el capítulo 3: "El parte aguas en el ejercicio de la investigación parlamentaria: el caso de la Compañía Nacional de Subsistencias Populares". En http://biblio.juridicas.unam.mx/libros/libro.htm?l=3607.
} 
bién estamos ante la completa permisibilidad para vender drogas de muchísimo mayor daño fisiológico y poder adictivo que la muy perseguida mariguana: los inhalantes, que además estas sí están dirigidas a estratos infantiles y juveniles sin amplio criterio. Ante las cuales al menos no se hacen ni los aspavientos de operativos y persecuciones, ni el desenfrenado gasto en aparatos de seguridad, y al menos por su "legalidad" no han contribuido a fomentar la violencia y a hacer desembocar al Estado mexicano en la condición de "fallido", justo por quienes exigen perseguir lo que ellos consideran drogas y por quienes dirigen la comandancia general de las fuerzas armadas norteamericanas.

\section{Propiedad y control productivo}

La privatización de las empresas estatales, como lo fueron los Bancos, previamente nacionalizados, Teléfonos de México, la Siderurgia Lázaro Cárdenas, los Ferrocarriles Nacionales, la Constructora Nacional de Carros de Ferrocarril, las carreteras, las aerolíneas, etc., supuestamente se hizo bajo la consigna de que el Estado era muy mal administrador. Esto, sentenciado justo por los que llegaban al Estado con la marca profesional de administradores y economistas, no dejaba de ser un mal antecedente para el propio lugar político que ocupaban o, al menos, una abierta confesión de limitaciones. Incluso, la secuencia del cambio total del papel del Estado se proponía instrumentarlo primero en la economía y, luego después, en lo político, primero la privatización y después la democracia.

Cuando si se ve la manera de privatizar no fue repartiendo a la sociedad lo que se consideraba propiedad social como llegaron a ser las privatizaciones en la ex Unión Soviética o incluso en algunas modalidades del proceso británico bajo el thatcherismo, como la campaña Tell Sid. Mucho menos se tomó en cuenta a los trabajadores de las empresas como para constituir comités organizacionales del trabajador colectivo de la producción y pasarles la tarea que los funcionarios del Estado se negaban a seguir cumpliendo con su confesión de ineptitud. Ni siquiera la peor opción, la de la apropiación por los sindicatos corporativistas ligados al sometimiento político estatal y a la corrupción autoritaria, nunca tuvieron la fortaleza e independencia para pretender actuar de nuevos patrones, lo que no dejaba de ser un punto favorable de la reforma que al menos procuraba la dirección autónoma que requiere el capital. El peor ejemplo de esa mixtión de visión sindicalista a favor de exprimirle todo lo posible a la empresa la veríamos seguir en pie en Petróleos Mexicanos con la participación directa del 
corrupto sindicato petrolero en el consejo de administración de la empresa. En donde la palanca de burócratas administradores ineficientes de ocasión en la alta jerarquía y la del sindicato corporativo aglutinador de los trabajadores por privilegios y canonjías, podían exprimir y tener controlados a los ingenieros y técnicos, a quienes procuraran establecer formas de eficiencia y racionalización ética y técnica de la empresa emblemática del Estado. Esa alternativa de darle poder a los técnicos y trabajadores en el proceso productivo para generar una dirección comprometida en el proceso productivo se dio por última vez, durante la primera mitad de los años setenta, en ciertas empresas nacionales como lo fueron la Constructora Nacional de Carros de Ferrocarril y Tabacos Mexicanos, mismas que fueron boicoteadas tanto desde las centrales sindicales oficiales como por la misma burocracia que se veía desplazada de su papel.

La retracción del Estado del papel estratégico que cumplía en la economía no fue una mera medida para aumentar la producción, para deshacerse de las empresas improductivas, representó un cambio primordial en el ejercicio de la intervención del poder estatal en ramas esenciales de la economía y que a su vez formaban parte integral de su relación con sectores prioritarios de la sociedad. El terreno agrícola y su sector campesino, la incorporación del favor obrero a través de su representaciones sindicales, el papel rector en los grandes proyectos de infraestructura, así como la dirección de empresas clave le daban al poder presidencial no sólo un papel económico prioritario, sino el fortalecimiento de su propio papel político. La economía mixta ha tenido muchas virtudes para darle un sentido estratégico a la ceguera del mercado pero sobre todo para darle un especio político a los diferentes factores de la producción, aun cuando una característica del modelo mexicano fue la muy restringida representación y papel de los técnicos y profesionistas en la estrategias de las empresas estatales o, inclusive, en su papel para organizarse con trabajadores de base o al menos como trabajadores de confianza.

De todos modos, quien desde principios de los ochenta tomó el modelo mexicano de economía mixta y lo llevó a su esplendor fue el régimen unipartidista chino como para pasar, de esos penosos años de control político total de la economía y de la Revolución cultural, que siguieron sufriendo Cuba y su insufrible falta de mercados, al menos artesanales o campesinos, y su ilegible Granma, o hasta 1989 con la Unión Soviética, pasar a la economía mixta apoyada por una estrategia política económica industrial auspiciada por el Estado. La diferencia es abismal, mientras que desde finales de los años cuarenta a la fecha el producto per capita chino se ha multiplicado unas 50 veces, los salarios 
mexicanos desde principios de los ochenta se han reducido en su valor adquisitivo varias veces. La diferencia comparativa del crecimiento podría llegar a ser de muchas decenas de veces... Y cuando en tiempo del neoliberalismo se habla de crisis en México siempre se recurre a la justificación ligándola al contexto internacional, pero la comparación con China está en chino, está prohibida y se pasa por alto. Inclusive ni siquiera la apertura económica de Deng Xiaoping llegó a instaurar las libertades y colores políticos mexicanos para su gato cazador de ratones chinos, aun cuando sí llegó a emular la matanza de Tlatelolco en Tiananmén. Mientras en México se regresa al ambiente del bandidaje imperante en el siglo XIX, de guerra sucia contra los movimientos sociales, de castración de la juventud más aguerrida, de demolición del papel social del Estado y se hacen cada vez más inverosímiles las opciones políticas institucionales.

\section{Subsunción Ideológica}

El anquilosamiento del poder en México es ya una cuestión de ideologías y personas. Enquistamiento de un mismo grupo amafiado y embotado por una su ideología "neoliberal", que han dando prueba fehaciente de no solamente resolver los problemas económicos mexicanos sino de su constante agravamiento, de la profundización de la crisis nacional en cada uno de sus aspectos, por no detallar detenidamente el maxisalinato que logra controlar rubros enteros del poder ejecutivo, inclusive por nepotismo, como lo son la Secretaría de Relaciones Exteriores, Hacienda y el control y desmantelamiento de la mayor empresa nacional: Pemex.

Si el fundamento más explícito para definir lo que son las ideologías corresponde a visiones del mundo asentadas en la diversidad de sociedades con amplios distingos de clase y de situaciones políticas que permiten concretarlas, en las sociedades modernas los distintos grupos políticos pueden ostentar sus diferencias centradas en visiones ideológicas distintas e, inclusive, opuestas en asuntos importantes. Se ha llegado a proclamar el fin de las ideologías justo cuando, acaso la más famosa, la de los países de Europa del Este bajo el control soviético que se liberaban de la opresión, descartaban la adjudicada ideología socialista científica formulada por Carlos Marx. Sin embargo, esas visiones también se constituían como certeras explicaciones del funcionamiento económico, pero al menos se nombraban estudios de economía política, donde en el fondo había excepciones, justificaciones y conflictos de la sociedad, como 
para no pensarlas absolutamente verdaderas y objetivas. Mientras la ideología capitalista ya neoliberal podía asentarse no solamente como un saber del mundo sino como la certeza de cómo es el mundo en el seno de la producción, clausurando todo posible cuestionamiento del proceso de explotación, de subordinación del trabajo asalariado al capital. ${ }^{3}$ Proclamar el triunfo del neoliberalismo como la visión objetiva y verdadera es justo el principio del dogmatismo que no acepta ni críticas y mucho menos perder el poder para continuar con el proceso de enriquecimiento por los medios políticos posibles. Por decirlo en pocas palabras, la economía como arte social no deja de tener una entraña política primordial. El neoliberalismo como privilegio ideológico que niega el acceso a lo político y al dominio de los recursos a las clases subordinadas es la forma moderna de encarnación de los privilegios económicos, con el capital financiero como nueva sangre azul. Y a una clase política corrupta y corta de miras comunitarias y nacionales, a un cíclope trastabillante que ya sólo le queda encarnar la tiranía porque ha perdido la venía de un reconocimiento legítimo a través de la libertad de pensamientos, de crítica, de asociación y de elección, sólo le queda seguir los dictados de una ideología imperial que se impone incluso hasta someter a sus propios ciudadanos, ya no digamos a los de las colonias en proceso de subsunción.

\section{Las imposiciones económicas}

Las restricciones de recursos sociales para quienes tienen que trabajar a cambio de salarios muy limitados, los estratos de ingresos más bajos, han servido para constreñir las acciones de la gente común, quienes naturalmente dedican más tiempo a tratar de mantener sus ingresos en detrimento del tiempo libre y el que podía dedicar a relaciones sociales que llevarán a la política o a la libre organización social. Ante la baja de salarios en el sector normal de la economía, se incrementan las maneras informales de obtener recursos. Y ya esto, en términos generales, ha llevado a que la economía informal pueda superar a la formal, en detrimento del Estado. Más de la mitad de los mexicanos obtienen sus recursos más allá de as reglamentaciones económicas del Estado. Esto todavía de forma más patética ocurre con la delincuencia, aparte de poner en jaque todo el sistema de justicia. La delincuencia no solo se ha fortalecido

${ }^{3}$ Para ver el desarrollo histórico de esta ideología ver Fernando Escalante Gonzalbo, Historia mínima de El neoliberalismo, México, El Colegio de México, 2015. 
en sus ámbitos tradicionales, sino que ha tendido a ocupar nichos que antes estaban reservados exclusivamente al Estado, como es el caso del cobro de derecho de piso para obtener un seguro de no agresión, en idéntica manera como se instituyó por amenaza el cobro de impuestos en la tradición real, cuando las exacciones reales no se habían impuesto como normales. Además, en una tendencia donde el pago de las cada vez mayores deudas por parte del Estado se han ido saldando con el progresivo incremento de impuestos a los ciudadanos -causantes menores o mayores. Lo que también ha llevado al incremento del impuesto al consumo directo, como medida para recabar ingresos de las clases informales y de las más menesterosas que ni siquiera están controladas por la contabilidad impositiva estatal.

No se puede dejar de mencionar que la deuda pública tiene ahora un papel más que relevante en la determinación de la capacidad de acción presidencial. Cuando la mayor parte de los recursos del gasto público son para su uso corriente, prácticamente todos los recursos para proyectos nuevos ligados al Estado se obtienen ampliando la deuda pública, de tal manera que en la primera mitad de la corriente administración de Pena Nieto se puede llegar a incrementar al menos en una tercera parte la deuda pública total, lo que constituye no sólo una medida que deja a las siguientes administraciones atadas de las manos, sino que establece ya una pérdida de la libertad política amenazada por los acreedores y bajo la velada amenaza del recurso al ejercicio de la violencia por los Estados imperiales, tal como ha sido recurrente en la historia de este país, y que no cambiará por mucho que la llamemos globalización.

Todas las exigencias políticas pactadas con los organismos internacionales como el Fondo Monetario Internacional o el Banco Mundial, o las maneras de instrumentarse el alza en los intereses a cobrarse por las deudas pactadas, acaban siendo concesiones para favorecer a los prestamistas y sus corporaciones, como lo ha sido la mencionada consigna de vender los bienes públicos, o, inclusive, las reglas económicas, sociales y políticas para incrementar el cobro de impuestos y asegurar el pago oportuno de las deudas públicas contraídas. Aún cuando ha sido el caso de quiebras privadas estratosféricas el Estado tampoco ha recurrido a avalar a los ciudadanos deudores sino a saldar las quiebras empresariales y bancarias con recursos públicos, como fue el escandaloso caso del FOBAPROA, que todavía seguirá cargando a cuestas la sociedad mexicana. Los intereses creados, las deudas contraídas por administraciones anteriores, el compromiso con antelación a un ejercicio de gobierno de los ingresos por impuestos y de las políticas específicas para lograr saldarlas, han llevado a atar 
las manos del ejercicio del poder ejecutivo, aun antes que cualquier persona determinada ocupe el cargo. Pero si esto se puede decir de la presidencia de la república, el caso de la libertad de endeudamiento con el que han operado los gobernadores de los estados ha llevado a ciertas entidades de la república a callejones sin salida, como es el caso en Coahuila con sus hermanos Moreira o Duarte en Veracruz, llegando esto a repetirse inclusive al tercer nivel del gobierno, esto es, en los municipios. ${ }^{4}$ De hecho, gran parte de la descentralización ha consistido en repartir fondos federales hacia los estados y municipios de una manera decisiva e inusitada en la tradición del presidencialismo: de 1995 a 2010 la entrega de este tipo de recursos por la federación se multiplicó por 207 veces, y sobre los que hay escasa rendición de cuentas. ${ }^{5}$

\section{Legitimidad y poder}

En cada uno de estos terrenos, el consenso público hacia el papel de la presidencia se ha ido mermando. Reforma tras reforma, cambio tras cambio, por usar el nombre de sus maniobras legislativas, desde los tiempos de Salinas de Gortari se ha ido expropiando y apergollando a la sociedad y sus libertades. El papel de la presidencia ha pasado de ser el mediador estatal al que los diferentes intereses de la sociedad recurrían para encontrar si no el juicioso punto medio, sí, al menos un límite al ejercicio de los intereses acaudillados por el dinero y el poder, eso que llaman poderes fácticos y que en otro momento más poético podían denominarse caciques de horca y cuchillo.

A sabiendas de un ejercicio del poder cada ves más faccioso, de una cantidad cada ves mayor de injurias, de expropiaciones, de delitos donde se encuentran trazas de los agentes del estado involucrados, de descontentos cada vez más acendrados, de derechos constitucionales interpretados con dolo, de asesina-

\footnotetext{
${ }^{4}$ La deuda pública de Coahuila pasó de 323 millones de pesos en 2005 a 36,675.8 millones de pesos en septiembre de 2011, según datos de la Secretaría de Hacienda y Crédito Público (SHCP) en CNN, 2 de julio de 2015, en http://mexico.cnn.com/adnpolitico/2015/07/02/deuda-millonaria-desvio-y-lavadode-dinero-los-3-strikes-de-moreira. Mientras que la deuda de Javier Duarte en Veracruz alcanza la cifra de 111,000 millones de pesos; en La Jornada, 6 de enero de 2016, en http://www.jornada.unam. $\mathrm{mx} / 2016 / 01 / 06 /$ estados/027nlest.

${ }^{5}$ Pasaron en 15 años de 49 mil millones de pesos a 1 billón 22 mil millones, más de 207 en 15 años y para ver la escasa rendición de cuentas en Arturo González de Aragón, "Transparencia y rendición de cuentas México: ¿Estado corrupto?” Proceso, 2 y 9 de marzo de 2012, http://hemeroteca.proceso.com. $\mathrm{mx} / \mathrm{p} \mathrm{p}=299856 \mathrm{y}$ http://hemeroteca.proceso.com.mx/?p=300561
} 
tos con clara motivación política, y de intereses extranjeros específicamente puestos por encima de los intereses y de las propiedades tradicionales de las comunidades mexicanas, la visión presidencial se ha tornado cada ves más parcial al formular y defender primordialmente los intereses imperiales. Cual cíclope cada vez más autista en el ejercicio dictado del poder, atrás de un armazón que lo protege tanto de la sociedad como de su propia chatez de miras, la presidencia de México ha propiciado la desarticulación y la balcanización de los territorios mexicanos que quedan a merced de corporaciones ilegales o legales, como ya claramente lo son las dictadas nuevas zonas económicas para el enclave de emporios extranjeros -liberados de imposiciones y con territorios cedidos a sus empresas extranjeras-, entre otras en la apreciada zona del istmo de Tehuantepec, cuyo flujo ferrocarrilero transatlántico puso en entredicho la inauguración redituable del Canal de Panamá, -y fue una de las concesiones que se le exigieron a Porfirio Díaz o a Carranza,${ }^{6}$ o la entrega de zonas petroleras o mineras a la explotación y contabilidad de las corporaciones transnacionales, muy por encima, incluso, si lo que se defiende es el derecho a la tradicional propiedad, del derecho de los propietarios de los terrenos superficiales a sus riquezas concomitantes. Pero bajo una supuesta descentralización democrática, lo que ha sucedido es dejarle las manos largas a los poderes regionales amordazando todo principio de control y participación ciudadana para darle sentido comunitario a los recursos, entre ellos los naturales o, al menos, supervisar y cuestionar a los poderes desatados de las diferentes instancias de gobierno estatales o municipales, que con prontitud copian y superan los modos presidenciales para beneficio del mejor postor.

En la tradición norteamericana el federalismo logró fundamentarse hasta 1788 cuando la elección del Presidente se ligó directamente al pueblo. La figura presidencial cobraba su propio peso al asentarse en la votación popular. A su vez, tres ámbitos serían los relevantes por encima de las atribuciones de los estados: el comercio entre estados y al exterior, la diplomacia y la guerra. Si en algo se encuentran semejanzas con la fundamentación del federalismo mexicano del siglo XIX, ise pueden mantener esas características en el caso de la reforma política mexicana, en donde el comercio ha quedado fuera del terreno ejecutivo a partir de los tratados internacionales con peso constitucional, el

${ }^{6}$ Carta de Villa a Zapata en Jesús Vargas V., Columbus 1916, declaración de guerra a EU, La Jornada, 12 de marzo de 2016, pp. 32 y 30. Manuscrito de Felipe Lascuráin sobre la entrevista Porfirio Díaz con el presidente Taft, en donde se discuten las concesiones petroleras a europeos y el papel del ferrocarril transoceánico del Istmo de Tehuantepec. 
control de la diplomacia está cada vez más deslavado y vuelto botín político de gobernadores y expresidentes, y el ejercicio de la guerra ha sido inoperante, en hora buena, hacia el exterior y hacia el ámbito interno se ha vuelto al uso policiaco cada vez más acendrado, justo "porque los civiles no han hecho su trabajo", como bien declara el general del ejército mexicano? ${ }^{7}$

\section{Transparencia y rendición de cuentas}

Arturo González de Aragón, de 2002 a 2009 al frente de la Auditoría Superior de la Federación, y quien no fue reelecto para su cargo dadas las presiones que en ese momento ejerció el presidente Felipe Calderón, en el texto sorprendentemente puntual y valiente, publicado en marzo del 2012, da cuenta de algunos de los aspectos de la corrupción que han podido salir a la luz pública a pesar de que muy generalmente no se han podido perseguir y castigar a los culpables, como es el caso del Fobaproa, de los Amigos de Fox, de la Estela de "Pus", de la muerte de los niños en la guardería $A B C$ en Hermosillo, la falta de contabilidad patrimonial, el uso inadecuado de recursos excedentes provenientes de la bonanza petrolera, la falta de rendición de cuentas del Poder Legislativo, y esto con todo y que la ASF depende de ese poder del Estado, el enorme gasto de comunicación del Poder Ejecutivo, la escasa rendición de cuentas y endeudamiento por parte de Estados y Municipios, la inseguridad por más de 45 mil muertos en 5 años del sexenio de Calderón, la nula justicia y aplicación de la ley, ya que de 1 a 2 por ciento de todos los delitos son castigados, los partidos políticos que manipulan leyes para no rendir cuentas y ser fiscalizados, el contubernio y corrupción entre servidores públicos y crimen organizado en casinos causante de 53 muertes en el Casino Royale en Monterrey, la corrupción y saqueo público en el despacho de gasolineras, la corrupción institucional del Tribunal Electoral del Poder Judicial de la Federación con sueldos de cerca 5.9 millones anuales, y, finalmente, la mala calidad de la educación en México pero la alta capacitación en los Partidos Políticos para cometer delitos electorales. González de Aragón además de señalar esas lacras públicas también propone medidas para terminar con la impunidad como lo es un diseño constitucional adecuado por el que se fortalezca la inde-

${ }^{7}$ Nota de Gustavo Castillo y Arturo Sánchez, "El Ejército está en las calles porque la autoridad civil no hizo su trabajo", La Jornada, 13 de marzo de 2016, p. 4. Y donde el general José Carlos Beltrán declara que le problema de la justicia civil frente a la militar, no es el fuero de la segunda, sino que las deficiencias de la primera obligarían a la segunda a acatar sus fallas. 
pendencia y la capacidad de sanción, haciendo incluso inatacables sus resoluciones, de órganos como el IFE, el IFAI, la misma ASF o la CNDH, y de otras especialidades como competencia, comunicación, administración tributaria, protección al consumidor y usuarios de servicios financieros; hacer públicas sus sesiones y resoluciones, propiciar la participación de académicos y sociedad civil para privilegiar los perfiles profesionales para dirigir las instituciones anteriores; evitar la intromisión de los partidos políticos en las designaciones de los titulares de las instituciones autónomas mencionadas, y reducir a la mitad los recursos para partidos y procesos electorales, quitar la excepción de que gozan los partidos para que sean fiscalizados por la ASF, establecer observatorios ciudadanos para supervisar las instituciones, acabar con todos los monopolios así como "exigir a los partidos políticos y candidatos a la Presidencia de la República proyectos de gobierno con visión de Estado y los compromisos que pretenden cumplir suscritos ante notario público" -lo que ya es pedir demasiado, por supuesto, pero vale la pena referirlo porque demuestra todavía optimismo en la humanidad-, y, finalmente, establecer fórmulas que hagan posible la gobernabilidad y, alcanzar un gran acuerdo nacional de todas las fuerzas políticas y de los poderes fácticos por el interés superior de la nación, "estableciendo consecuencias severas para los responsables de los incumplimientos."

También denunciará el autismo y la soberbia en los gobernantes que les impide cambiar de rumbo y los vuelve incapaces de representar a la sociedad. Este análisis y arenga de González de Aragón, que en ese entonces también se presentó ante el legislativo, ha tenido influencia en la actuación y en la demagogia de campaña del ejercicio de gobierno del peñato, pero por supuesto no se ha cumplido en su fondo. ${ }^{8}$ Sin embargo, justo para la transparencia y la rendición de cuentas olvida el eslabón más importante y frágil, el del uso y abuso de los medios de comunicación, que se han vuelto indispensables en el control político de campañas y del ejercicio de poder, del conocimiento público y, acaso, la más eficiente forma de presión para forjar o detener la actuación del poder. También en este terreno el control del poder del capital sobre el ejercicio profesional de los comunicadores es patente, y no se piensa regular en términos legislativos para defender la libertad tanto de expresión como de profesión, de la misma manera en que un dueño de hospitales no tiene derecho a formular diagnósticos médicos, o un ingeniero tal es responsable técnico de una obra y no el dueño.

${ }^{8}$ Ibíd. A partir de julio de 2013, González Aragón supervisa la aplicación de recursos del programa nacional de prevención del delito que tiene como presupuesto solo $\$ 2,500$ millones en el año: La Jornada, 26 de julio de 2013, en http://www.jornada.unam.mx/2013/07/26/politica/012nlpol 
Tanto por el desplome de su legitimidad por el continuo descrédito de las elecciones, así como por la restricción de las facultades del poder ejecutivo y la incapacidad financiera o política real para actuar y ganarse el reconocimiento público, el poder presidencial ha perdido con un ejercicio oprobioso el respeto público. A esto ha contribuido la dejadez con que se ha permitido deslucir las presentaciones públicas de su investidura, particularmente ante el Congreso. Ya desde el último informe presidencial de De la Madrid en el que se enfrenta al descrédito y a la desplegada posibilidad de fraude electoral, ante el surgimiento de de un voto popular volcado hacia la figura de Cuauhtémoc Cárdenas, se destapa la cruenta entrada desde entonces de la inconmensurablemente nefasta violencia política para suprimir piezas claves en el tablero político y electoral, como lo fueron los asesinatos de Buendía, Ovando y Gil. Al mismo tiempo que se invita a la esperanzada ciudadanía a expresar su voluntad, se destapan los demonios de la caja de Pandora, por los que las plagas que asolan hasta hoy a México no se han vueltos a encerrar por el regreso del fuero de la justicia y una limpia expresión de la voluntad del pueblo. Esto ha llevado, entre otras imágenes, hasta descomponer la ritualidad del informe presidencial, el único momento establecido de rendimiento de cuentas ante la nación. Ha sido no solamente un retroceso en la imagen pública de la convivencia institucional, sino la ruptura del respeto a la representación soberana de la máxima figura personal en investidura de la Nación, que no hace diferencias entre el representante del gobierno y el del Estado. Más todavía cuando regresa el rey que cree que nadie vio su esquizofrénica desnudez, su entrega al desenfreno de suprimir las piezas por rebelarse de su propio tablero. Ya bajo la maldición de Colosio, de Ruiz Massieu, de Ovando y Gil y muchos tantos otros hombres políticos suprimidos, sin la claridad de la justicia no hay democracia posible en el reino de Pedro Páramo... El cíclope seguirá llamando a sus víctimas para engullirlas en su pestilente paso a la modernidad...

\section{El oráculo}

Ya desde "La crisis en México" de Daniel Cosío Villegas, publicado en 1947, se ponen en entredicho las tres principales metas de la Revolución Mexicana expuestas como la reforma agraria, la organización obrera y la libertad política. ${ }^{9}$ El poco éxito económico de la primera, el predominio de las organizaciones

${ }^{9}$ Daniel Cosío Villegas "La crisis de México" en Cuadernos Americanos, XXXII, marzo-abril, pp. 29-51, accesible en http://www.editor.pbsiar.com/upload/PDF/crisis_en_mexico.pdf. 
obreras con el apoyo estatal frente al empresariado como fracaso productivo de la segunda meta y la inalcanzable libertad política por el servilismo del congreso a la voluntad presidencial, por la falta de crítica y por la incapacidad de formulación de una opinión pública, por el predominio de la corrupción para incorporar y someter a la clase política, están en el origen de una nueva clase opresora que sin autoridad moral ni política destruye cualquier ideal de igualdad y justicia social revolucionarias, fundiéndose en un mismo espasmo los descendientes de la corrupta Revolución y la derecha conservadora carente de generosidad y comprensión. Mientras que en México no ha ocurrido la prueba indefectible que podría comprobar un carácter genuinamente democrático: el triunfo electoral de un partido o grupo ajeno y aun opuesto al gobierno, y más ahora que la duda no solamente cae sobre personas sino sobre ideologías, cuando "las diferencias entre la Revolución Mexicana y los partidos conservadores pueden ser tan insubstanciales, qué estos pueden ascender al poder ya no como opositores, sino como hijos legítimos". Leo este ensayo sugerido por el texto de José Agustín Ortiz Pinchetti "Don Daniel Profeta certero e ignorado", ${ }^{10}$ justo en los momentos finales de la escritura del presente texto, para entregarse en 24 horas, y a pesar de mi texto que trata esas cuestiones medulares, no deja de asombrarme cómo, setenta años después, podemos repetir la misma senda sin tomar ni siquiera en cuenta la profundidad de nuestros grandes críticos e intérpretes, hasta llegar a la peor de las tragedias: la pérdida de la libertad e independencia frente a Estados Unidos que, justo como advertía Don Daniel Cosío Villegas, hoy es llamado a resolver nuestros problemas en aras de una prosperidad desconocida, por añadidura, México dejará de ser México en lo que venga de fuera, se hundirá para no rehacerse con una personalidad propia.

\section{Fuentes}

Castillo, Gustavo y Arturo Sánchez, "El Ejército está en las calles porque la autoridad civil no hizo su trabajo", La Jornada, 13 de marzo de 2016.

Cosío Villegas, Daniel, "La crisis de México" en Cuadernos Americanos, XXXII, marzoabril, pp. 29-51, accesible en http://www.editor.pbsiar.com/upload/PDF/crisis_en_ mexico.pdf.

${ }^{10}$ La Jornada, 13 de marzo de 2016, p. 10. 
Eisenstadt, S.N., "El estudio del despotismo oriental como sistema de poder total", en Revista de Administración Pública, núm. 45, enero-marzo 1981,pp. 35-47 en http:// www.juridicas.unam.mx/publica/librev/rev/rap/cont/45/pr/pr5.pdf

Escalante Gonzalbo, Fernando, Historia minima de El neoliberalismo, México, El Colegio de México, 2015.

González de Aragón, Arturo, "Transparencia y rendición de cuentas México: ¿Estado corrupto?", Proceso, 2 y 9 de marzo de 2012, http://hemeroteca.proceso.com. $\mathrm{mx} / \mathrm{p} \mathrm{p}=299856$ y http://hemeroteca.proceso.com.mx/?p=300561

La Jornada, 13 de marzo de 2016.

Vargas V., Jesús, "Columbus 1916, declaración de guerra a EU", La Jornada, 12 de marzo de 2016.

Zamora, Guillermo, CONASUPO Leche radiactiva, negligencia sin castigo, Proceso, 26 de abril, 2014, en http://www.proceso.com.mx/370752/leche-radiactiva-la-negligenciasin-castigo; https://achtung00.wordpress.com/2011/01/12/la-leche-radioactiva-dela-conasupo/ Mora-Donatto, Cecilia, Treinta años de Investigaciones parlamentarias en México (1977-2007). Qué investigaron los diputados federales?, Instituto de Investigaciones Jurídicas, UNAM, 2013.

La Jornada, 26 de julio de 2013, en http://www.jornada.unam.mx/2013/07/26/ politica/012nlpol

CNN, 2 de julio de 2015, en http://mexico.cnn.com/adnpolitico/2015/07/02/deudamillonaria-desvio-y-lavado-de-dinero-los-3-strikes-de-moreira.

La Jornada, 6 de enero de 2016, en http://www.jornada.unam.mx/2016/01/06/ estados/027nlest. 
EL "PACTO POR MÉXICO": REFORMAS DEL ESTADO

César Alejandro Hernández Mendoza

U

T no de los puntos esenciales del neoliberalismo es la Reforma del Estado, en la medida que histórica y teóricamente el Estado Benefactor ha sido el adversario a vencer por los llamados neoliberales. En México esto ha sido muy claro, en particular desde el segundo lustro de la década de los años ochenta. El régimen priista tuvo que enfrentar luchas, incluso al interior del propio partido, por aceptar o no una serie de reformas que modificaban claramente el papel del Estado en la economía, la organización del proceso político, del proceso social; en fin, su "adelgazamiento". La derecha, a través de grupos empresariales, de medios de comunicación y del Partido Acción Nacional (PAN) presionaron duramente para impulsar tales cambios. En esa lucha interna, la postulación de Carlos Salinas de Gortari como el candidato del Partido Revolucionario Institucional (PRI) significó una derrota para el nacionalismo revolucionario y el eventual reformismo neoliberal de Salinas y Zedillo; provocó, también, la salida de un sector del partido, el cual se aglutinó con las izquierdas para conformar la izquierda hegemónica que sería el Partido de la Revolución Democrática. El PRI se encontró en medio de la izquierda y la derecha, ambas demandaban más reformas para "transitar a la democracia".

En el discurso político y el discurso teórico, la transición política mexicana tuvo como principal objetivo la alternancia en el Ejecutivo, la pluralidad en ambas Cámaras del Congreso de la Unión, acompañados de procesos paralelos en las entidades federativas. El tránsito a la democracia implicaría, entonces, el fin del Presidencialismo, división de poderes y un federalismo real, el fin de décadas del régimen priista. Han pasado cuatro décadas desde la elección del candidato "único", López Portillo, que tuvo como respuesta la Reforma 
Política de 1977 y las reformas políticas subsecuentes llegaron, paulatinamente, el primer Congreso sin mayoría calificada, los primeros senadores y el primer gobernador de oposición, el primer Congreso sin mayoría simple y el Presidente de oposición, y todo se replicó en las entidades federativas. Pero, ¿se acabó el Presidencialismo, hay división de poderes, un mayor federalismo, fin del régimen priista? ¿Transitamos a la democracia? Desde la perspectiva de la democracia como repartición del poder, parece que sí, desde la perspectiva de las promesas de la democracia, tal vez no. Veamos.

\section{Respuesta a la Crisis del Sistema Político: Reformas del Estado.}

La forma más recurrente de interpretación de los males de la política mexicana fue a través de la categoría del sistema político, en tanto servía para atribuir tales males al régimen construido por la Revolución Mexicana a través del partido -mal definido-, de "Estado, definido como autoritario casi al nivel de las dictaduras de América del Sur.

La Reforma de 1977 trajo a los plurinominales; la de 1983, aun cien más; en 1988 perdió el PRI la ciudad capital, llegaron los primeros senadores opositores, la elección presidencial provocó la mayor pérdida de legitimidad; nuevas reformas trajeron "concertacesiones" para dar a Ruffo -en 1989- y Barrio -en 1992-, las primeras gubernaturas opositoras; en 1994, una elección construida sobre la base de la desconfianza pero con la organización del IFE trajo como un Presidente, a un candidato emergente por el asesinato del original, que poco hizo para que el PRI perdiera la mayoría simple y poder ganar cualquier decisión en la Cámara de Diputados frente al llamado G-4 (PAN, PRD, PT y PVEM) y menos aún para que ganara el candidato del PRI la Presidencia, con lo que llegó la soñada derrota del PRI para los Pinos, en 2000. Des entonces volvió a ganar el PAN en 2006 y el mapa político es claramente distinto a como era en 1976.

Paralelamente se fue dando la llamada Reforma del Estado, primero como respuesta a la quiebra del país con las reformas descentralizadoras y de ajuste con De la Madrid, y claramente con Salinas y Zedillo para liberalizar y privatizar, empresas y sectores públicos; en suma, el llamado Neoliberalismo. Con ello se buscaba hacer frente a la crisis económica y avanzar el desmantelamiento del partido de Estado. 


\section{Pacto por México: ¿resultado de la transición democrática?}

En agosto de 2011, las dirigencias de los partidos de la Revolución Democrática, del Trabajo (PT) y Movimiento Ciudadano (MC) se comprometieron a ir juntos en la elección de julio de 2012, respondiendo a la convocatoria hecha por Andrés Manuel López Obrador; en noviembre registraron el Movimiento Progresista mediante un convenio de coalición que incluía candidatos al Congreso y a gubernaturas con base en una Plataforma Electoral que tenía como objetivo principal "un proyecto alternativo de nación que busca cambiar la política neoliberal". El Movimiento Progresista demandó la invalidez de la elección en cuestión, la cual fue avalada por el Tribunal Electoral el 31 de agosto siguiente, para la instalación del Congreso. Inmediatamente-septiembre 4-, pese a que había un compromiso legislativo explícito en la Plataforma frente al electorado, el PRD convocó a un conformar el "Frente Parlamentario Progresista" para impulsar una agenda legislativa. En nombre del PRD, su líder en el Senado, Miguel Barbosa, aclaró "estar abiertos al diálogo con todas las fuerzas políticas, incluido el PRI"; revelando una postura de "acuerdo" con el PRI y el PAN. Aunque coincidía aun con el PT y MC en respaldar las acciones que tomará López Obrador frente al gobierno de Peña Nieto y en acompañarlo a la concentración popular en el Zócalo días después. Paralelamente, ese mismo mes, siendo ya "presidente electo", Peña Nieto firmó con la OCDE un acuerdo de cooperación que enfocaría su gobierno, reunido con José Ángel Gurría, Secretario General de la OCDE. En noviembre siguiente, Gurría recibió en la entrada de la sede de la OCDE en París a Peña Nieto, durante su gira por Europa antes de tomar posesión. Ahí el "presidente electo", Peña Nieto, dio una "conferencia magistral" y fue calificado por Gurría como el "líder de una nueva generación de mexicanos".

El $1^{\circ}$ de diciembre de 2012, mismo día de la que Peña Nieto "tomó posesión", PRI, PAN y PRD firmaron el "Pacto por México", formalizando una agenda neoliberal y la salida explícita del PRD del llamado del Proyecto Alternativo de Nación. El texto suscrito advierte: "se requiere de un Pacto Nacional que comprometa al gobierno y a las principales fuerzas políticas dispuestas a impulsar un conjunto de iniciativas y reformas".

En la segunda semana de enero se encontraron Gurría y Peña Nieto por tercera vez, y durante el evento Gurría entregó en propia mano al Presidente Peña Nieto, el manual Getting it Right. Agenda estratégica para las reformas en México, con fecha de edición desde diciembre de 2012. El texto toma en cuenta los 13 "Decisiones Presidenciales" que delineó Peña Nieto en su discurso 
de toma de posesión, y los 95 compromisos del "Pacto por México" pero se observan puntos definidos desde la campaña presidencial, mucho antes de su primer encuentro público y la impresión del estudio del OCDE, que fue realizado en sintonía con el programa de gobierno de Peña Nieto. En particular, el mencionado libro propone modificaciones legales-constitucionales (denominadas "recomendaciones") en las reformas "estructurales": laboral, educativa, de telecomunicaciones, hacendaria y, por supuesto, energética.

A la mitad de su gobierno, septiembre de 2015, Peña Nieto declaró que las "reformas estructurales" del Pacto habían sido ya aprobadas y evaluó el proceso, dijo: "el Pacto por México fue un acuerdo que construyó la agenda sobre los temas que era importante abordar: impulsar reformas y hacer cambios estructurales". Y enumeró como las "reformas estructurales" son: la Laboral; la Educativa, de Telecomunicaciones, la Hacendaria, la Financiera, de Transparencia, la Energética, la Electoral, del Distrito Federal y de Anticorrupción. Hubo otras reformas diseñadas para profundizar en el modelo neoliberal. El "Pacto" logró prácticamente el control del Congreso, consolidando una mayoría asociada que no tendría ninguno de sus partidos políticos firmantes por sí mismo. Al firmar el "Pacto", PRI, PAN y PRD aprobaron todos los "compromisos" ahí enunciados.

\section{Las Reformas del Pacto por México}

Las principales implicaciones de cada una de las reformas del "Pacto" fueron:

Reforma Laboral. Reforma patronal contra los trabajadores y el pacto social. Permitirá flexibilizar los contratos de trabajo con contratos a corto plazo para tareas determinadas, contratos por horas, despido casi gratuito, el trabajador no tendrán derecho más que a un año de salarios caídos (a petición de Gurría y Casterns por las "necesidad de que haya facilidad para el despido"). Va a acabar con el mercado interno, con la seguridad social.

Reforma Educativa. Esta llamada "recomendación" de la OCDE, no es una Reforma Educativa sino laboral, no entra al fondo. Crea una Junta de Gobierno con autonomía constitucional, innecesaria, una cúpula por encima de la SEP. Su autonomía no existirá porque será una estructura que se van a repartir entre los partidos del Pacto. 
Reforma en Materia de Telecomunicaciones. Su objetivo central de atacar a los monopolios, es un dictado de la OCDE. Abre para la inversión extranjera al 100 por ciento en las telecomunicaciones y al 49 por ciento a la televisión y radiodifusión, contra la soberanía mexicana, ya que las telecomunicaciones son un área estratégica de seguridad nacional. No es un problema técnico, es político; respecto a monopolios, sabemos cuáles son dominantes, no existe un equilibrio porque dejan de lado la posibilidad real de competencia a la radiodifusión democrática: la indígena, la comunitaria, la pública; el derecho de réplica favorece a los grades medios de comunicación.

Reforma Fiscal-Hacendaria. Las leyes del ISR, del IVA y del IEPS mantienen intactos los privilegios de los grandes grupos económicos, que se apropian del 60 por ciento del PIB, cuando debieran aportar, también un 60 por ciento de la recaudación total, pero sólo pagan impuestos equivalentes al 7 por ciento. El ISR: trato especial a corporativos; crece el cobro a personas físicas y mantiene el gravamen a las ganancias en bolsa, como los fondos de retiro; profundiza la desigualdad entre personas físicas y morales. IVA: profundiza la desigualdad social y distorsionan las condiciones para las empresas de la frontera norte, como la homologación del IVA. El IEPS: "impuestos ecológicos" a importación de combustibles fósiles, legalizan la entrada de las transnacionales en la importación de combustibles y la entrada de gasolineras extranjeras, de la mano de la reforma energética. Generará un hoyo fiscal, por la entrega del petróleo tendrá que cubrirse con deuda, mutilando el gasto público e impuestos futuros para no romper paradigmas neoliberales del "déficit cero".

Reforma Financiera. Profundiza la extranjerización del sector financiero, protegiendo intereses de bancos extranjeros; anula el poder de regularlos; la paridad del peso y su sobrevaluación garantiza sus ganancias; protección a la banca extranjera, especuladora. El Banco Central despoja al gobierno del manejo del dinero, obligado a la "disciplina fiscal" en inversión social y sectores estratégicos, introduce las corporaciones en todas las áreas de la economía, salud, educación, en los servicios públicos, obligando a la población a pagar por lo que debería ser responsabilidad pública. La Banca de Desarrollo se rediseña con base en criterios de mercado y rentabilidad, sin impulsar la producción y el empleo; menos industrias, menos agricultura, menos economía formal, menos empresas públicas. Los créditos solo a empresas que "ofrecen garantías crediticias"; no a las que tendrían que arriesgar sus reducidos activos. El acreedor 
podrá cobrar de forma expedita, a través de embargos. Apoyo ágil y expedito a las instituciones bancarias con problemas, procura maximizar la recuperación de valores de los activos para que no caigan en insolvencia, que la banca no pierda. Da poderes plenipotenciarios al socio fundador, facultado a tomar las decisiones que corresponderían a las asambleas de accionistas. Régimen para que gobiernos extranjeros puedan participar en el capital social de sociedades operadoras de sociedades de inversión; sociedades distribuidoras de acciones de sociedades de inversión; y sociedades valuadoras de acciones de sociedades de inversión.

Reforma en materia de Transparencia. El órgano garante federal tiene competencia sobre los órganos de transparencia de los estados y del D.F.; sus decisiones puedan ser motivo de controversia constitucional ante la Suprema Corte de Justicia y la facultad del Consejero Jurídico de Presidencia a impugnar las decisiones del órgano garante. El mecanismo de designación de los comisionados del organismo reitera el reparto de cuotas entre los partidos. El Ejecutivo puede vetarlo u objetarlo. Futuro Consejo Consultivo por cuotas partidistas. Deja fuera como sujetos obligados de trasparencia a los poderes mediáticos, que se benefician de concesiones con enormes recursos públicos e influencia social y política.

Reforma Política-Electoral. Decisión centralista de establecer un aparato nacional para quitarle a los gobernadores, la autoridad y el manejo de las elecciones. Contradicción entre el "órgano nacional" y los futuros órganos estatales, cuyos Consejeros dependerán de las cuotas partidistas. Suben un punto porcentual más para que las minorías puedan acceder al Congreso, en favor de la hegemonía de los partidos del Pacto. No ataca 2 temas fundamentales para la democracia: 1) El exceso de dinero, la compra de posiciones y la compra de Presidencias de la República; y, 2) los medios de comunicación. Ridícula la "causal de nulidad". No ataca el conflicto de intereses.

Reforma Anticorrupción. Los organismos son controlados por el Presidente de la República o elegidos por sus aliados en el Congreso. Crea un Sistema Nacional Anticorrupción (que integra al IFAI, la ASF, y la futura Fiscalía Anticorrupción, sin coordinación, no es un sistema). Es Centralista: el órgano anticorrupción nacional, podrá atraer cualquier caso local, ignorando que el sistema de la corrupción viene desde las más altas esferas del gobierno federal; el Presi- 
dente de la República está presente en un Consejo Consultivo a través de un representante; no aclara que el Presidente no va a intervenir, ni la designación, remoción u objeción al nombramiento del Fiscal General. El titular del órgano anticorrupción será designado por los Partidos. Ignora la corrupción como conflicto de interés o el cabildeo. No estudia las causas de la corrupción, ni los nuevos delitos; lo deja a 10 leyes secundarias que vendrán cuando Peña termine su gestión.

Reforma Política del Distrito Federal. Es para cerrar el paso a la izquierda al gobierno de la Capital de la República, caja de resonancia nacional, con el mayor desarrollo económico. "Constituyente" amañado: 60 diputados, por la lista de los partidos; luego 14 van a ser Senadores a propuesta de la Junta de Coordinación Política, 14 por la Cámara de Diputados; Peña Nieto designará a 6 constituyentes, el Jefe de Gobierno también a 6. La Reforma es una gran claudicación, es una gran entrega que han logrado sin constitución, sin monerías, sin reformas, ahí está el gobierno desde hace años sin esta reforma, del 60 por ciento que tiene van a pasar a cerca de 20 .

Reforma Energética. El "Pacto", precisamente, es el resultado de las demandas de esas empresas como "recomendaciones" de agencias internacionales. Sus ejes básicos fueron: cambiar la naturaleza del régimen de propiedad de la nación sobrelos recursos energéticos; transformar la naturaleza jurídico-administrativa de las instituciones públicas encargadas de la energía, de organismos públicos descen tralizados a empresas productivas del Estado; y, nueva relación tributaria de la industria con la hacienda pública. Esto a partir de tres ejes: 1) replantear el régimen de propiedad; 2) trasmutar de lo público en privado, y 3) aplicar principios de gobierno corporativo a las empresas públicas. La modificación de los artículos 25, 27 y 28 constitucionales tienen como premisas generales: 1) "crear" la figura de "empresas productivas del Estado"; 2) redefinir la "propiedad de la Nación"; y, 3) redefinir las "áreas estratégicas en materia energética", eliminando la rectoría del Estado y la exclusividad del mismo, para imponer la posibilidad de "asociarse" con el sector privado. Los 21 artículos transitorios de la reforma constitucional perfilaron cambios profundizados en las 9 leyes creadas y modificaciones a 12 leyes vigentes. Ahí destacan: replantear el estatus laboral de los trabajadores de PEMEX y CFE; nuevas modalidades de contratación y formas de pago de las contraprestaciones derivadas de cada contrato; nueva modalidad de propiedad de los recursos de la Nación, por medio de los contratos: el 
booking o registro contable; criterios que PEMEX deberá cumplir, con los requisitos para ser merecer asignaciones para la exploración de los campos; la utilidad primordial del sector energético, dado su carácter estratégico, para exploración y extracción del petróleo y demás hidrocarburos, así como del servicio público de transmisión y distribución de energía eléctrica; nuevos mecanismos para dar máxima transparencia de los contratos, así como un sistema de auditorías externas de la operación de los contratos; facultades para la Secretaría de Energía para conducir la política energética; a la Comisión Nacional de Hidrocarburos y la Comisión Reguladora de Energía, las cuales tendrán una nueva naturaleza como órganos reguladores en materia de energía, con personalidad jurídica y patrimonio propio; fideicomiso, Fondo Mexicano del Petróleo para la Estabilización y el Desarrollo, cuyo fiduciario será el Banco de México; crean dos organismos descentralizados: Centro Nacional de Control del Gas Natural, para la operación del sistema nacional de ductos de transporte y almacenamiento, y el Centro Nacional de Control de Energía. Además de una Agencia Nacional de Seguridad Industrial y de Protección al Medio Ambiente del Sector Hidrocarburos; la incorporación de la "ocupación temporal"; reestructuran los principios fiscales y presupuestarios se pueden advertir fundamentalmente en las dos leyes de reciente creación, y que desnudan las verdaderas intenciones gubernamentales con respecto a la administración de la renta petrolera.

\section{Pacto Por México: Consenso Neoliberal y fin de la Oposición}

En los hechos, el "Pacto por México" implicó el apoyo total del PRD a una agenda neoliberal, por la confrontación con López Obrador, o por la convicción en los compromisos del Pacto. La hegemonía de la "teoría del consenso" en torno al proyecto neoliberal, que manipula el concepto Oposición para descalificar los planteamientos contrarios a sus intereses. ${ }^{1}$

Norberto Bobbio definió oposición como: "la unión de personas o grupos que persiguen fines contrapuestos a aquellos que detentan el poder económico o político"2. Desde el punto de vista institucional, la Oposición se fue constru-

${ }^{1}$ El Diccionario de la Real Academia define oposición en 11 acepciones, ninguna vinculada con "acuerdo", "trato" o "pacto; al contrario, destaca: "partidos que en un país se oponen a la política del Gobierno; en los cuerpos legislativos, minoría que habitualmente impugna las actuaciones del Gobierno; y cada uno de los cuerpos deliberantes, o de los sectores de la opinión publica adversos al poder."

${ }^{2}$ Bobbio y otros, Diccionario de Política, México, Siglo XXI Editores. 
yendo a través de la representación, la cual se funda en que el Congreso esté representado el pueblo y sus múltiples grupos sociales; ahí la división de poderes determina la que el Congreso ejerce la función de control de los asuntos públicos en manos del partido gobernante, aun cuando por la representación de los partidos, el partido gobernante desde el Ejecutivo tiene su representación, este partido no define una función de control del ejecutivo. Stefano Bartolini destacó el papel de los partidos como representantes de sectores sociales, proyectos políticos, económicos, e ideológicos: "los partidos políticos tienen un natural carácter conflictivo en la medida que son base para la existencia de identidades colectivas, grupos y movimientos potencialmente en conflicto, por lo que una función importante es agregar lo intereses y demandas que surgen de la sociedad en forma de políticas y programas generales". 3

Ernesto Laclau planteó desde inicios de los años ochenta este dilema para la izquierda frente al neoliberalismo. ${ }^{4}$ A lo que hemos asistido en las últimas décadas con el triunfo del neoliberalismo ha sido a la pérdida de identidad de la izquierda y excusándose en la "modernización", partidos de izquierda o socialdemócratas han cambiado su práctica política, autodenominándose de "centroizquierda"; sosteniendo que la diferencia entre izquierda y derecha se ha transformado en obsoleta. Promoviendo una política de "centro radical". Conforme a la teoría de consenso, la función obligada de los partidos, cualquiera que sea su ideología, es frente aceptar y negociar los temas para llegar a acuerdos "mayoritarios".

Para estos y otros autores, es evidente que la oposición es la base de la democracia. En este sentido, una minoría legislativa opositora autentica frente a una mayoría, tiene limitaciones, pero a partir de los instrumentos propios de oposición tiene una ruta estratégica que desmitifique el supuesto de que la decisión de la mayoría parlamentaria es incuestionable. Si la mayoría parlamentaria no es legítima o disfraza sus límites legales, los ciudadanos pueden acudir a derechos constitucionales hasta la desobediencia civil para reclamar justicia de la mayoría legislativa.

Desde la perspectiva teórica y práctica más contemporánea, el problema de la oposición a las políticas neoliberales ha cobrado importancia en diversos países en Europa (Inglaterra con Corwin, España con "Podemos", en Grecia con Syriza) y no digamos con el "eje sudamericano". Hay señalamientos a los

\footnotetext{
${ }^{3}$ Pasquino y otros. Manual de Ciencia Política, Alianza Universidad Textos.

${ }^{4}$ Ernesto Laclau y Chantal Mouffe, Hegemonía y Estrategia Socialista, 1985, México, FCE.
} 
partidos de izquierdas tradicionales por considerar que han sido cómplices de las élites neoliberales, los partidos "socialdemócratas". Este pareciera el caso del PRD, no sólo en sus discursos sino con la firma del Pacto. Una izquierda "moderna", que "negocia", que llega a "consensos", que intenta justificar a una izquierda centrista, en realidad, es de derecha. Mostrarse de acuerdo en que toda forma de consenso sólo resulta de lograr una articulación hegemónica entre las partes. En cambio, como partido oposición, debiera desarrollar proyectos democráticos radicales a través de la transformación profunda de las relaciones de poder existentes, a través de un consenso que sea resultado de las demandas sociales, populares, como extensión de las luchas democráticas por la igualdad y libertad en el que se incluyan ampliamente las relaciones sociales.

Más allá de la retórica y el debate político o teórico de la crisis de las izquierdas y su papel en los procesos políticos, las Plataformas Electorales, las cuales parten de principios ideológicos y políticos, deben traducirse en programas de gobierno o legislativos. Son, además, la base sobre la que los candidatos hacen campaña para ganar votos de ciudadanos que confían en esos principios y, al darles el voto, la representación se convierte en mandato legislativo. Esta cuestión es una obligación legal, el Código Federal de Procedimientos Electorales, vigente en 2012, señala en su artículo 27 los partidos tenían que "presentar una plataforma electoral sustentada en su declaración de principios y programa de acción y obligación para sus candidatos sostener y difundir esa plataforma durante la campaña; igual es un obligación para las colaciones electorales y cada uno de los candidatos de la coalición -artículos 96 y $222-$ y el mismo COFIPE, en su artículo 228, establecía que las actividades de campaña debían propiciar la exposición, desarrollo y discusión ante el electorado de los programas y acciones fijados por los partidos políticos en sus documentos básicos y la Plataforma registrada.

Para el caso del PRD, su Plataforma fue la del "Movimiento Progresista", que destacan como tesis centrales:

- "La política económica neoliberal arroja un saldo negativo para la mayoría de los mexicanos, (...) es un deterioro del tejido social".

- "Derrotar a la oligarquía en el terreno político y por la vía pacífica para establecer en México una verdadera democracia".

\footnotetext{
${ }^{5}$ Plataforma de Campaña de la Coalición Movimiento Progresista.
} 
En este planteamiento se centró la campaña electoral de todos los candidatos de Movimiento Progresista. Por ello, el mandato de la oposición obliga a todos los candidatos ganadores de una curul sostener ese mandato adquirido en campaña y no llegar a acuerdos que sean contrarios a los compromisos de la campaña, como lo fue el "Pacto" con la derecha y el gobierno neoliberal.

En el caso del "Pacto por México", las iniciativas tienen definitiva influencia con las instituciones vinculadas con el neoliberalismo. Es una nueva etapa de profundización de la apertura a la privatización y capitales extranjeros, particularmente de sectores estratégicos nacionales, minimizando el Estado en favor de la oligarquía integracionista, que el PRD solía acusar como atentado contra la soberanía nacional y el pueblo mexicano. Estos compromisos fueron repetidos en la campaña de Peña Neto, están en el estudio referido de la OCDE y en la implementación al momento, de dichas reformas. El PRD tenía un compromiso con sus electores que era la plataforma electoral para esa campaña. Aun con eso, es muy claro que desde los primeros días posteriores había ya un "diálogo" con el PAN y PRI que culminó con la firma del "Pacto por México".

¿Qué podemos decir frente a la hegemonía discursiva del acuerdo o la "cruda" realidad de la racionalidad política? Desde la Reforma Política de 1977 la derecha y la izquierda han tenido grandes beneficios, casi todas las promesas de cada iniciativa se cumplieron: se pluralizaron ambas Cámaras del Congreso de la Unión, y paulatinamente perdiendo el PRI la "mayoría calificada" y la mayoría simple; llegó la alternancia en el Ejecutivo, dos sexenios, hasta que regresó el PRI; y lo mismo sucedió antes en casi todas las entidades federativas. Pero este tránsito a la democracia ¿se tradujo en el fin del Presidencialismo, en mayor división de poderes y un federalismo real?

La hegemonía presidencial nunca se fue, ni con un Presidente "débil" como Fox; al contrario, desde la década de los años ochenta no veíamos actos tan presidencialistas como los actuales en Palacio Nacional, cada vez que convoca la Oficina de la Presidencia. La división de poderes, desapareció con el "Pacto por México", con reformas impensables hace un lustro, aprobadas en minutos en las legislaturas locales. El federalismo regresa a una etapa centralizadora como lo revela el Mando Único Policiaco que es, para especialistas, el fin del espíritu del municipalismo. A nivel de gubernaturas y congresos locales, ni que hablar. Al final, el "Pacto por México" radicalizó la hegemonía neoliberal y su resultado: el fin del Estado nacional revolucionario. Parece que el Estado mexicano cambio claramente pero el denostado Sistema Político Mexicano no parece haber cambiado. 


\section{Fuentes}

Bobbio y otros, Diccionario de Política, México, Siglo XXI Editores.

Laclau, Ernesto y Chantal Mouffe, Hegemonía y Estrategia Socialista, 1985, México, FCE. Pasquino y otros. Manual de Ciencia Política, Alianza Universidad Textos.

Plataforma de Campaña de la Coalición Movimiento Progresista. 


\section{CONSIDERACIONES SOBRE EL CONCEPTO GRUPO DE INTERÉS-PRESIÓN}

Fernando Ayala Blanco

\section{Inventio. Aproximación al concepto de 'grupo de interés-presión'}

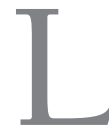

a retórica clásica plantea que la inventio es la búsqueda de argumentos o contra-argumentos sobre algún tema en particular. El orador u escritor, en posesión del tema de su discurso, desarrolla argumentos con el objetivo de persuadir, convencer y conmover de un conjunto de tópicos, los cuales se van llenando de contenidos (ideas, conceptos o estereotipos). En mi opinión, es conveniente presentar una aproximación al concepto de grupo de interés-presión para entender la problemática que se desató en torno al edificio "H" de la Facultad de Ciencias Políticas y Sociales, en Ciudad Universitaria.

Veamos, si se considera este concepto como categoría de análisis en la Ciencias Sociales, es pertinente dimensionarlo a la luz de la 'teoría de grupos'. No cabe duda que en la historia de los seres humanos se ha presentado una interacción entre comunidad política e intereses de grupo. Vale la pena señalar que el poder se ejerce en cinco grandes esferas que tienen vasos comunicantes entre sí: la política, la económica, la militar, la religiosa y la cultural. Los grupos de interés-presión se desenvuelven justamente en estas esferas de poder, ya sea para sacar adelante sus intereses u obliterar los de sus adversarios. No es casualidad que Wrigth Mills escribiera, en su libro La élite del poder, que cuando nos referimos a la minoría del poder estamos hablando de

los círculos políticos, económicos y militares que, como un conjunto intrincado de camarillas que se trasladan e imbrican, toma parte en las decisiones que, por lo menos, tienen consecuencias nacionales. En la medida en que se deciden los 
acontecimientos nacionales, la élite del poder está constituida por quienes los deciden. [...] En esta época particular una conjunción de circunstancias históricas ha dado lugar al nacimiento de una minoría de poder; que individuos de los círculos que componen esa minoría, separada y colectivamente, toman ahora las decisiones claves y que dado el aumento y la centralización del poder, las decisiones que toman o que dejan de tomar tienen consecuencias para mayor número de gentes que nunca en la historia de la humanidad. ${ }^{1}$

Con lo dicho hasta aquí, cabe preguntarse, ¿qué se entiende por grupo de interés-presión? Este concepto hace referencia a un grupo en el que sus integrantes comparten intereses, deseos y actitudes, que los impele a influir en las acciones de las políticas públicas para tratar de consolidar y legitimar sus intereses. Los líderes y representantes de un grupo de interés-presión asumen un rol importante en el proceso de mediación, negociación, persuasión, disuasión o presión, entre sus representados y los otros -que pueden ser funcionarios públicos de alto nivel, legisladores o todos aquellos que toman las decisiones importantes en las políticas públicas.

Lo cierto es que cuando un grupo de interés no consigue lo que desea o pretende a través de los canales legales o formales de la negociación, la liberación o la construcción de consensos, presiona mediante mecanismos informales que pueden rayar en la ilegalidad y la violencia.

El objetivo principal de este tipo de grupos es el de presionar en defensa de sus intereses; y éstos pueden ser tanto materiales (económicos, contratos, concesiones) como subjetivos (ideales, valores, creencias, principios). Los grupos de presión desarrollan sus actividades, principalmente, en cuatro [ámbitos] de influencia: el gobierno, la opinión pública, los partidos políticos y los demás grupos. Éstos intentarán influir en la toma de decisiones y en la agenda gubernamental para lograr sus aspiraciones e intereses. ${ }^{2}$

Es importante señalar que un grupo de interés-presión -a diferencia de un partido político- no busca conquistar el poder político y mantenerlo el mayor tiempo posible; en realidad pretende influir en él, para consolidar sus intereses

\footnotetext{
${ }^{1}$ Wrigth Mills, La élite del poder, México, Fondo de Cultura Económica, 1957, pp. 25-34.

2 Fernando Ayala Blanco y Salvador Mora Velázquez, "Introducción", en Grupos de poder. La toma de decisiones en un modelo democrático, coordinado por Fernando Ayala y Salvador Mora, México, UNAM, 2012, p. 14.
} 
de grupo. De ahí la importancia de la negociación, la deliberación, la persuasión, el consenso, el cabildeo y el manejo del disenso. Es decir, de la retórica en el buen sentido del término, para promover la cooperación y la concordia y cerrarle el paso a la ingobernabilidad y la sinrazón en una comunidad política.

El politólogo francés Maurice Duverger, por ejemplo, señala que los grupos de interés-presión no ejercen directamente el poder, sino que actúan sobre él; en pocas palabras, tratan de influir en los detentadores de poder, en aquellos que toman las grandes decisiones para la sociedad. Es claro que los grupos de interés-presión tienen representantes en las asambleas legislativas y en los gobiernos, pero "el vínculo entre [éstos] y el grupo del que dependen permanece discreto o en secreto." 3

Los grupos de interés-presión representan los intereses de los distintos sectores que integran el gran mosaico social; es natural que el aumento de la especialización provoque la multiplicación de los grupos. Hoy vemos que dirigentes, políticos, obreros, campesinos, empresarios, intelectuales, estudiantes, entre otros, se integran en agrupaciones u organizaciones para que sus intereses sean tomados en cuenta. Los latifundios, los gremios, las compañías comerciales, las facciones y otros grupos similares, fueron los primeros antecedentes de los grupos de interés-presión. Vale la pena reiterar que los grupos de este tipo son asociaciones voluntarias de individuos que se agrupan para defender o posicionar sus intereses.

Al igual que los partidos políticos, éstos surgieron en el siglo XIX, principalmente en Gran Bretaña y Estados Unidos. Cobraron vida gracias a los avatares de la modernidad, en particular a tres factores que afectaron el desarrollo de las comunidades políticas, a saber: a) los procesos de industrialización; b) el reconocimiento del derecho de la libre asociación; y c) la regulación a través de mecanismos parlamentarios de las más diversas actividades económicas. ${ }^{4}$

Los primeros estudios que abordaron de forma sistemática la acción e impacto de los grupos organizados fueron The Process of Government: A Study of Social Pressures, del norteamericano Arthur Fisher Bentley, publicado en 1908; y The Governmental Process: Political interests and Public Opinion, del también norteamericano David Truman, publicado en 1951. Aun cuando hay cuarenta y tres años de distancia entre una obra y otra, ambas fueron investigaciones pioneras en el estudio de los grupos de interés-presión. Además, creo conveniente

\footnotetext{
${ }^{3}$ Maurice Duverger, Sociología política, Barcelona, Ariel, 1968, p. 376.

${ }^{4}$ Miguel Jerez "Los grupos de presión", en Rafael del Aguila (ed.), Manual de Ciencia Política, Madrid, Editorial Trotta, 2000, p. 291.
} 
señalar que -durante todo el siglo Xx- se han cruzado los estudios sobre la teoría de grupos con los estudios sobre la teoría de élites. Si se quiere ahondar en esta línea de investigación, pueden consultarse los trabajos realizados en el Proyecto PAPIME "El estudio de los grupos de poder en México", DGAPA-UNAM, publicados en tres volúmenes: Grupos de poder. La toma de decisiones en un modelo democrático (2010); Grupos de poder en México. Alcances y perspectivas (2011); y Tendencias de los grupos de poder en México (2012).

Arthur F. Bentley plantea que el objetivo principal en el estudio de toda forma de vida social es el análisis de los grupos y asegura que una reflexión de esta naturaleza va más allá que una simple clasificación. El politólogo norteamericano sostiene que la actividad política implica conflicto entre grupos que contienden en libertad a favor y defensa de un interés. Y remata afirmando que la tarea de la Ciencia Política consiste en diferenciar los intereses que precisan las acciones de los individuos y que les articulan en una infinidad de relaciones y por lo tanto de grupos. ${ }^{5}$ Los planteamientos de Bentley sostienen que

el proceso de gobierno se reduce a un fenómeno de ajuste entre grupos, por encima de las instituciones. En otras palabras, el ejercicio del poder político es el resultado de la competencia entre distintos grupos; competencia que provoca un "ajuste" entre éstos. La categoría de grupo se encuentra definida de acuerdo a sus objetivos en un proceso político, de tal suerte que se establecen vasos comunicantes entre el grupo, su actividad y sus intereses. Por consiguiente, los miembros de un grupo siempre tendrán intereses comunes, que se traducirán en ciertas acciones, actividades y políticas específicas. ${ }^{6}$

David Truman, siguiendo los pasos hollados por Bentley, señala que un grupo de interés-presión es cualquier agrupación que, partiendo de una o más posturas compartidas, empuja hacia adelante ciertas reivindicaciones frente a otros grupos u organizaciones de la sociedad. ${ }^{7}$ Ahora bien, tanto Bentley como Truman le dan la facultad a todos los grupos de tener el mismo rango y las mismas capacidades, sin diferenciar los tipos de acción y sin tomar en cuenta los recursos de que disponen. Siguiendo este orden de ideas, caemos en cuen-

${ }^{5}$ Arthur F. Bentley, The Process of Government: A Study of Social Pressures, Blomington, Principia Press, 1908.

${ }^{6}$ Fernando Ayala y Salvador Mora, op. cit., p.11.

${ }^{7}$ David Truman, The Governmental Process: Political interests and Public Opinion, Nueva York, Knopf, 1951, p. 33. 
ta de que los politólogos norteamericanos consideran al Estado, los partidos políticos y el ordenamiento de un sistema político, como otros grupos más. En mi opinión, esta perspectiva es muy vaga e insuficiente, pues no considera las modalidades de interacción entre los grupos existentes en una sociedad y sus diferencias con los partidos políticos y las instituciones gubernamentales.

En el inicio de la década de los sesenta del siglo Xx, el sociólogo francés Jean Meynaud realizó un profundo estudio de los grupos de interés-presión que se publicó bajo el título Los grupos de presión. Esta obra profundizó y amplió las aportaciones de Bentley y Truman. El investigador José de Jesús Gómez Valle señala que

los trabajos que Meynaud dedicó a los grupos (principalmente en Francia pero también en otras latitudes), sobresalen por su óptima mezcla de los argumentos teóricos-metodológicos con un profundo análisis descriptivo. Además, señalan las dificultades con las que se enfrenta quien pretende realizar cualquier análisis sólido. [...] La obra de Meynaud describe también, aunque no siempre con precisión, la fuerza y la eficacia de las presiones practicadas en un contexto establecido. ${ }^{8}$

Es importante mencionar que Jean Meynaud establece una diferencia entre grupo de interés y grupo de presión, pero indicando la estrecha relación entre ambos y la posibilidad de tránsito de uno a otro. La primera categoría se refiere al "conjunto de individuos que basándose en una comunidad de actitudes, expresan reivindicaciones, alegan pretensiones o toman posiciones que afectan, de manera directa o indirecta, a otros actores de la vida social." Ahora bien, un grupo de interés se convierte en grupo de presión en el momento en que los líderes de la organización "utilizan la acción sobre el aparato gubernamental para hacer triunfar sus aspiraciones y reivindicaciones." 10

Lo cierto es que en los grupos de interés-presión destacan cinco características: el número de sus integrantes; la capacidad financiera; la capacidad de organización; la identificación de sus miembros con los intereses que defienden; y la capacidad de presionar e intimidar al gobierno y a otros actores sociales para conseguir sus objetivos. Y sus formas de acción son las siguientes:

\footnotetext{
${ }^{8}$ José de Jesús Gómez Valle, El cabildeo de los grupos de presión a la Cámara de Diputados en México durante la LVIII Legislatura (2000-2003), Guadalajara, Instituto Electoral del Estado de Jalisco, 2006, p.30.

${ }^{9}$ Jean Meynaud, Los grupos de presión, Buenos Aires, Editorial Eudeba, 1962, p. 12.

${ }^{10}$ Ibid. p. 25.
} 
la persuasión y disuasión a través de los medios masivos de comunicación y de contactos personales influyentes; la corrupción mediante el soborno y el cohecho a funcionarios públicos, medios de comunicación e integrantes de partidos políticos; y la intimidación que puede gravitar de la resistencia pasiva a la acción violenta. ${ }^{11}$

De ahí, pues, que un grupo organizado pueda presionar por medio de la amenaza, el poder del dinero y el sabotaje de las políticas públicas. Sin embargo, esto no significa que se quiera perjudicar estructuralmente las acciones de gobierno, en realidad se busca condicionar su actuación, ya sea para influir en la toma de decisiones o negociar a su favor. En esta perspectiva caben la huelga de algún sindicato o las movilizaciones de protesta que eventualmente pueden implicar situaciones de violencia. Las tácticas y métodos de los grupos de interés-presión pueden ir de la esfera constitucional a la inconstitucional, por lo tanto transitan de lo legal a lo ilegal o de lo formal a lo informal de un sistema político. La legitimidad es muy importante, pues pueden suscitarse acciones ilegales e informales pero legítimas para un sector amplio de la sociedad civil. Cierto, lo más adecuado para un grupo de interés-presión es realizar acciones apegadas a un estado de derecho y legítimas ante la opinión pública, y dejar la presión extrema como última opción.

Creo conveniente reiterar el valor que tiene para un grupo de interés-presión la negociación, la construcción de consenso, el manejo del disenso y el cabildeo. Sobre todo si su impacto e influencia pretende que sea en la arena parlamentaria. En este caso, hay cinco formas de influir o presionar, ya sea en la Cámara alta, la Cámara baja o en algún partido político:

a) Tratando de conseguir una representación directa en las cámaras mediante el apoyo a candidatos miembros del grupo que, una vez elegidos, defienden los intereses del mismo.

b) Financiando campañas electorales a candidatos no miembros del grupo a un cargo parlamentario.

c) Encargando la defensa regular de sus intereses a determinados parlamentarios, por lo regular a aquellos que se vieron beneficiados por el financiamiento de campañas.

d) A través de la audiencia (hearing) fórmula típica en Estados Unidos, donde las comisiones correspondientes confrontan datos con los representantes de los grupos.

${ }^{11}$ Idem. 
e) Mediante el cabildeo (lobbying), es decir, en la estimulación y transmisión de comunicación, de alguien distinto a un ciudadano que actuará en su propio nombre, hacia alguien. Aquí la propaganda masiva es tan importante como el contacto individual con los parlamentarios. ${ }^{12}$

La organización de una comunidad política implica la creación de puestos y cargos con poderes de mando; a su vez, los puestos y cargos son sometidos a los poderes de mando. Aquí cobra relevancia el concepto de élite, pues desvela la capacidad de manipulación y control de amplios sectores sociales que tiene ésta. En todos los grupos humanos es posible encontrar una minoría que mande y otra que dirija. Dicho con otras palabras, el poder no lo ejerce una sola persona ni tampoco toda la ciudadanía en su conjunto, en realidad lo ejerce una minoría, una élite o una clase oligárquica. En todo grupo de interés-presión siempre destacará una élite o minoría selecta.

Sin duda alguna, los seres humanos siempre hemos intentado seleccionar a los mejores para que nos guíen con virtud. Pero también es cierto que somos seres duales, afectados por la luz y la oscuridad o, como diría Ficino, somos ángeles y demonios al mismo tiempo. Los que toman las grandes decisiones que afectan a la sociedad muchas veces se equivocan, por lo tanto, las personas que conforman un grupo de élite no son necesariamente las más capaces ni las más preparadas ni las mejores. De aquí se desprende el criterio de la meritocracia. En efecto, si una persona ejerce el poder en los altos círculos quiere decir que sumó méritos y consolidó una posición de privilegio. Esto puede generar una falsa imagen de capacidad y alta calificación.

El sociólogo y filósofo italiano Wilfredo Pareto planteó, en los inicios del siglo XX, la tesis de que los hombres son desiguales en todos los campos de su actividad. Asimismo, rechazó abiertamente el concepto marxista de las clases sociales y, en cambio, presentó la categoría de élite como un elemento sustancial para entender las relaciones sociales. En opinión de Pareto, es necesario la 'circulación de las élites', pues de lo contrario sería imposible mantener el equilibrio social y político. En este punto, señala la pertinencia de distinguir entre élite y sociedad civil:

[Se debe formar] una clase con aquellos que tienen los índices más elevados en el ramo de su actividad, a la que [daríamos] el nombre de clase selecta (élite).

${ }^{12}$ Miguel Jerez, op. cit., pp. 308-312. 
Para el estudio que realizamos, el del equilibrio social, es útil aún dividir en dos esta clase, es decir, que separaremos a aquellos que, directa o indirectamente, tienen participación notable en el gobierno, quienes constituirán la clase selecta de gobierno; el resto será la clase selecta que no es de gobierno. ${ }^{13}$

Plantea que la élite es una minoría dirigente y que la base de una sociedad depende justamente de la circulación de sus élites. De modo que cuando una élite es incompetente, incapaz e ineficaz, será reemplazada por otra que sea competente, capaz y eficaz. Por supuesto que una élite no puede ser ni totalmente abierta ni totalmente cerrada. Hay contingencia, azar y movilidad en ellas, y están sometidas a la constante presión de la sociedad civil. Es evidente, dice Pareto, que deben renovarse mediante la participación de la ciudadanía, pero dicha participación tiene que ser acotada.

No está por demás denotar que para Pareto la democracia es, en el mejor de los casos, un mal necesario:

Un régimen de esta naturaleza siempre se enfrentará al hecho de la existencia de una élite gobernante que buscará ante todo realizar sus propios intereses, en detrimento de los intereses de la mayoría. Por tanto, la élite tratará de convencer a la comunidad entera de aceptar sus propios intereses como si fueran los de la sociedad civil en su conjunto. [...] Se podría decir que las élites no son permanentes, ya que el desgaste del ejercicio del poder político hace que circulen. No sólo disminuyen en cantidad, sino también en calidad, dando paso a la incorporación de nuevos elementos provenientes de otros estratos de agregación social, y echando andar la llamada circulación de las élites. Para Pareto la oligarquía, en cualquier régimen, es un fenómeno inevitable. Defiende la idea de que en un mundo tan complejo como el nuestro debemos abocarnos a la búsqueda de una élite funcional para la sociedad. ${ }^{14}$

Gaetano Mosca, otro importante politólogo italiano y contemporáneo de Pareto, sostiene que en toda sociedad siempre encontraremos el fenómeno de la dominación de unos sobre otros: una minoría organizada, a la que él llama 'clase política', domina con regularidad a la mayoría desorganizada. Así, pues, la dominación se sustenta no tanto en la fuerza, sino en el acuerdo tácito que

\footnotetext{
${ }^{13}$ Wilfredo Pareto, Forma y equilibrios sociales, Madrid, Alianza Editorial, 1980, p. 64.

${ }^{14}$ Fernando Ayala Blanco, "Élites, grupos de interés y cabildeo", en Cabildeo y conflicto de intereses, México, Senado de la República-Instituto Belisario Domínguez, 2012, p. 192.
} 
surge entre gobernantes y gobernados: ambas partes reconocen el fundamento del poder ejercido y obedecido en un universo común de valores y sentimientos que él llama 'fórmula política'.

En su célebre artículo "La clase política", escrito en 1896, dice que en toda sociedad existen dos clases de personas: la de los gobernantes y la de los gobernados. Y señala que

la primera, que es siempre la menos numerosa, desempeña todas las funciones políticas, monopoliza el poder y disfruta de las ventajas que van unidas a él. En tanto, la segunda, más numerosa, es dirigida y regulada por la primera de una manera más o menos legal, o bien de un modo más o menos arbitrario y violento, y a ella le suministra, cuando menos aparentemente, los medios materiales de subsistencia y los indispensables para la vitalidad del organismo político. ${ }^{15}$

En los sistemas políticos modernos encontramos la existencia de una clase dirigente, una clase política, una minoría selecta, que son personas influyentes en la dirección de la cosa pública, y a la que la sociedad civil le confiere de buen grado la dirección de las políticas públicas y el ejercicio del poder político. Constantemente nos topamos y enfrentamos con el mando y dominio de una minoría relativamente homogénea, solidaria y organizada. Sin embargo, nos es tan simple, pues a veces somos gobernados y a veces gobernantes; en ocasiones somos sometidos y padecemos los estragos del ejercicio del poder, y en ocasiones lo detentamos y ejercemos. No cabe duda que el Estado y las estructuras de mando son inherentes a todo sistema político; la verticalidad del poder es ineludible. Y en la cima de ésta, se localizan los grupos de élite que dominan los hilos del poder.

En suma, el debate contemporáneo en torno a los grupos de interés-presión oscila entre la indignación de gran parte de la sociedad civil como resultado de la formación de rapaces élites de grupos y la ponderación en la preparación, el conocimiento, la experiencia, la prudencia y la mesura, de nuestros líderes sociales que encabezan dichas élites. El horizonte que queremos vislumbrar como comunidad política es el de un buen gobierno, que sea capaz de resolver los conflictos sociales.

${ }^{15}$ Gaetano Mosca, La clase política, México, Fondo de Cultura Económica, 1984, p. 106. 


\section{Dispositio. Disposición de los elementos argumentativos de acuerdo a un discurso}

Antes de presentar los argumentos del grupo de intelectuales y artistas que pretende demoler el edificio " $\mathrm{H}$ " de la Facultad de Ciencias Políticas y Sociales o, en su defecto, demoler los cuatro últimos pisos; y también presentar los contra-argumentos de la comunidad de la Facultad para salvar el edifico; es pertinente explicar en qué consiste el dispositio en la retórica clásica. Ésta se divide en cuatro elementos:

a) Exodium. El orador o portador de un discurso trata de ganarse al auditorio y anuncia el plan de su argumentación.

b) Narratio. Se anuncian los hechos.

c) Confermatio. Se plantean los argumentos de los oradores o partes involucradas y se tratan de refutar o contra-argumentar.

\section{A. Exodium}

A finales de enero de 2016, un grupo de artistas e intelectuales comenzó una iniciativa denominada "Salvemos al Espacio Escultórico", que se publicó en change.org. El documento está dirigido al Rector de la UNAM, Dr. Enrique Graue Wiechers, al Secretario de Cultura del Gobierno Federal, Lic. Rafael Tovar y de Teresa, al Director del Patrimonio Mundial del inAH, Dr. Francisco López Morales, a la Directora y Representante de la Oficina del UNESCO en México, a la comunidad artística y cultural, y a todos los ciudadanos; la misiva fue firmada inicialmente por 100 artistas e intelectuales y con el paso de los días ha recaudado alrededor de doce mil firmas. La petición es demoler parte del edifico " $\mathrm{H}$ " de la Facultad de Ciencias Políticas y Sociales de la UNAM, pues -según la misiva- atenta contra el sitio inaugurado en 1979, en el que participaron artistas de la talla de Federico Silva, Manuel Felguérez, Helen Escobedo, Hersúa, Sebastián, Mathias Goeritz y Roberto Acuña. El argumento central es que dicho edificio destruye la armonía del lugar. Con base en lo anterior, el grupo de artistas e intelectuales exige destruir los cuatro niveles superiores del nuevo edificio "H", construido en los terrenos de la Facultad de Ciencias Políticas y Sociales. 
En respuesta, el Dr. Julio Amador Bech, académico de la Facultad de Ciencias Políticas y Sociales, defendió la existencia del edifico " $H$ ". Los argumentos de Julio Amador representan el sentir de la comunidad de políticas y hacen eco en la opinión pública. En una carta abierta a la comunidad de la Facultad de Ciencias Políticas y Sociales y a la sociedad civil en general, explica que "su construcción responde a la misión principal de la Universidad Nacional Autónoma de México, que es la docencia, la investigación, la producción de nuevos conocimientos, científicos y humanísticos, y la difusión de los mismos." Y lanza una serie de cuestionamientos que al día de hoy no han sido respondidos: "¿Por qué no hicieron público su punto de vista antes o durante la construcción del edifico H? ¿Por qué han esperado hasta ahora?” Además, señala lo difícil que es obtener recursos para la educación pública en momentos de crisis económica.

En términos generales, estos son los argumentos iniciales de ambas partes. Pero, ¿cuáles son los hechos y profundización de la problemática en torno al nuevo edificio?

\section{B. Narratio}

Enseguida reproduciré la esencia de las cartas, tanto del grupo de artistas e intelectuales, publicada en change.org, como la de Julio Amador, publicada en ark.la-fondark. De esta manera se podrán entender mejor los hechos, la problemática y la controversia, que ha desatado la construcción del Edificio " $\mathrm{H}$ " de la Facultad de Ciencias Políticas y Sociales.

\section{B.1 Salvemos el Espacio Escultórico}

El Espacio Escultórico, inaugurado en la Ciudad Universitaria de la UNAM en 1979 [...] es sin duda, una de las obras más importantes de Land Art en el mundo y, junto con las Torres de Satélite, la escultura monumental más importante del país. Es un lugar en la Ciudad de México, donde sin ver edificios e inscrito en un círculo de 120 metros de diámetro marcado por los 64 prismas que lo delimitan, se revela el paisaje y la topografía originales del sur de la ciudad. Su forma circular alude a la pirámide de Cuicuilco, primera en Mesoamérica, integrando así, la arquitectura prehispánica con el arte moderno y contemporáneo.

Al interior del área de la Reserva Ecológica del Pedregal de San Ángel y de la Zona de Amortiguamiento de la Zona Núcleo declarada por la UNESCO como 
Patrimonio de la Humanidad, es una obra que debe ser valorada y protegida como un bien cultural de la UNAM, del país y del mundo entero. Lamentablemente eso no ha sucedido. Debido al escaso mantenimiento, por no decir deterioro y al hecho de permanecer cerrado los fines de semana, [...] se ha sumado ahora la construcción del edifico "H" de la Facultad de Ciencias Políticas y Sociales, que albergará aulas, cubículos de investigación y oficinas y que se diseñó sin prever su desastroso efecto en el paisaje del Espacio Escultórico. Es sabida la necesidad que tienen las Facultades para ampliar su oferta académica y por ende su infraestructura, a ello sería absurdo oponerse. Lo que resulta un aberrante descuido fue el emplazar un edificio vertical en el eje oriente del Espacio Escultórico - uno de los puntos más atractivos del mismo, ya que desde ahí se observan los volcanes-, sobre todo considerando que existen terrenos en el campus y soluciones arquitectónicas que no hubieran resultado en la destrucción del paisaje.

[...] En este caso resulta aun más grave que la propia Universidad Nacional a través de sus instancias responsables relativas al Patrimonio y a Obras, así como de la Facultad de Ciencias Políticas y Sociales, [...] hayan incurrido en este grave daño a su propio patrimonio, que es de los mexicanos y del mundo. ${ }^{16}$

La misiva fue firmada por un grupo de artistas e intelectuales, sumando cien firmas en su lanzamiento. Con el paso de los días se han agregado más firmantes.

Veamos ahora la carta que está circulando en redes sociales e internet, elaborada por el Dr. Julio Amador Bech y que hace eco con el sentir de la comunidad de la Facultad de Ciencias Políticas y Sociales, y con muchas otras personas dentro y fuera de la UNAM.

B.2 De la casa \#85: Documento en defensa de la Facultad de Ciencias Políticas y Sociales de la UNAM/JAB

Un grupo de personas que buscan proteger la estética del Espacio Escultórico, pretenden demoler el recién construido Edificio " $\mathrm{H}$ " el cual, gracias a un gran esfuerzo de gestión de recursos, de diseño y construcción acaba de ser concluido en la Facultad de Ciencias Políticas y Sociales de la UNAM. Estas nuevas instalaciones académicas, destinadas a ser aulas, cubículos para profesores y oficinas del Posgrado, alivian los graves problemas de falta de espacios educativos que

\footnotetext{
${ }^{16}$ Se puede consultar la carta completa en change.org Salvemos el Espacio Escultórico.
} 
ha padecido nuestra Facultad, debido a su crecimiento en los años recientes, en función del éxito que sus actividades académicas han tenido.

[...] La construcción del Edificio "H" responde a la misión principal de la Universidad Nacional Autónoma de México que es la de la docencia, la investigación, la producción de nuevos conocimientos, científicos y humanísticos, y la difusión de los mismos. Quienes pretenden la demolición del edificio ignoran por completo este hecho irrefutable. La misión de la UNAM no es la de constituirse en un espacio para la producción de Land Art. Me pregunto si esas personas saben lo difícil que es obtener recursos para la educación pública en estos tiempos. Me pregunto si les importa que los jóvenes mexicanos que asisten a la UNAM se formen adecuadamente, en instalaciones idóneas para tales fines. ${ }^{17}$

\section{Confermatio}

En este espacio se presenta el argumento central de cada una de las posiciones antagónicas. Para tal efecto, continuaré reproduciendo las partes sustanciales de cada uno de los discursos argumentativos (citaré fragmentos de las distintas misivas).

\section{C.1 Salvemos el Espacio Escultórico}

El grupo de artistas e intelectuales que está presionando a las autoridades de la UNAM para demoler los cuatro niveles superiores del edifico " $\mathrm{H}$ ", argumenta lo siguiente:

No queremos ni podemos permitirnos que se siga atentando contra nuestro patrimonio cultural, artístico, urbano y natural. Por lo mismo exigimos que se restaure de manera integral el Espacio Escultórico. [...] Exigimos desde luego la demolición de los cuatro niveles superiores del nuevo edificio, una solución que aunque pueda parecer radical es la única manera de restaurar la integridad de la obra artística, en la que el paisaje, como ya se dijo, es parte integral. Si tenemos que poner en una balanza un edificio mediocre y relativamente pequeño, contra la escultura pública más importante de nuestro país, resulta

\footnotetext{
${ }^{17}$ Se puede consultar la carta completa en arkeopatias.wordpress.com; ark-la fondark.
} 
una obligación de la UNAM salvar su propio patrimonio y el compromiso que tiene hacia la nación y el mundo por conservarlo y darlo a conocer, ya que es de todos. ${ }^{18}$

C.2 De la casa \#85: Documento en defensa de la Facultad de Ciencias Políticas y Sociales de la UNAM/JAB

Por su parte, Julio Amador Bech, haciendo eco con la comunidad de políticas, contra-argumenta diciendo que el grupo "Salvemos el Espacio Escultórico"

en vez de pensar razonablemente, anteponen sus criterios de fundamentalismo estético. [...] ¿Por qué no hicieron público su punto de vista antes del proceso de construcción del Edificio "H" o durante el mismo? ¿Por qué han esperado hasta ahora? Su actitud es totalmente arbitraria, pues también la Torre de Rectoría y el Centro Cultural Universitario, particularmente la Biblioteca Nacional, que se encuentra a 300 metros, afecta la visual del Espacio Escultórico. ¿Debemos también demoler esos edificios para mejorar la estética del Espacio Escultórico? Me pregunto si esas distinguidas personas del medio artístico mexicano no obedecen, sin saberlo, a intereses ajenos a la Universidad que intentan causar un grave problema a nuestra máxima casa de estudios y enfrentar a las autoridades universitarias a un dilema sumamente difícil de resolver.

[...] La posición de esas personas vulnera los derechos que tenemos los miembros de la Facultad de Ciencias Políticas y Sociales de la UNAM de construir las instalaciones idóneas que permitan el desempeño de nuestras labores académicas. Además, esas personas mienten pues es falso que el Edificio "H" esté construido sobre el Área protegida de la UNAM.

[...] No queremos ser parte del problema, sino parte de la solución, por lo cual proponemos un acuerdo negociado: realizar una intervención artística sobre la fachada del Edificio "H" que lo integre al paisaje. ${ }^{19}$

\section{Epilogus}

El epilogus es un recurso de la retórica clásica que sirve para recapitular las distintas etapas de la argumentación y, de esta manera, tratar de conmover

\footnotetext{
${ }^{18}$ Change.org, op. cit.

${ }^{19}$ wordpress.com, op. cit.
} 
y persuadir al auditorio (en este caso a la opinión pública, a las autoridades universitarias y a la ciudadanía en su conjunto).

En mi opinión, el grupo "Salvemos el Espacio Escultórico", integrado principalmente por artistas e intelectuales mexicanos, tiene las características principales de un grupo de interés-presión.

En primer lugar, el grupo está presionando -mediante la movilización y el apoyo de los medios de comunicación- a las autoridades de la Universidad Nacional Autónoma de México. Pretenden anteponer sus intereses a los de la máxima casa de estudios (docencia, investigación y vida académica).

En segundo lugar, están desarrollando actividades de influencia en el gobierno de la Ciudad de México, la opinión pública y otros grupos de la sociedad civil. A través de la presión mediática, intentan impactar en la toma de decisiones y en la agenda de gobierno de la UNAM.

En tercer lugar, el grupo cumple con las características suficientes para considerarlo un grupo de interés-presión: tiene un número amplio de integrantes, organizados bajo la égida de artistas e intelectuales de renombre, por ejemplo, Teodoro González de León o Pedro Reyes; tiene capacidad financiera y de movilización; y presiona a través de los medios masivos de comunicación y de contactos personales influyentes, para imponer sus intereses sobre los de la comunidad, no sólo de políticas, sino de la UNAM en su conjunto. El interés principal de este grupo es demoler parte del edificio " $H$ " de la Facultad de Ciencias Políticas y Sociales, bajo un argumento de "fundamentalismo estético".

Cabe preguntarse si realmente los orquestadores de este grupo de interéspresión obedecen a un criterio estético y patrimonial de Land-Art u obedece a un interés financiero. Quizá ese sea el motivo para presionar a las instancias de gobierno de la UNAM. ¿Por qué se están inconformando hasta ahora y no cuando empezó la construcción? Es mucha coincidencia que lo hagan justo en el inicio del 2016, en el momento en que se han anunciado recortes presupuestales en el gobierno federal, que también afectan a la UNAM. De los primeros recortes que se mencionaron fue la compra de obra plástica.

Sin duda, el Espacio Escultórico es una magna obra de arte, Patrimonio de la Humanidad, que debemos conservar y resguardar. Pero un juicio de gusto estético no debe anteponerse al espíritu académico y humanista de nuestra máxima casa de estudios.

Debido al crecimiento y expansión de la Facultad de Ciencias Políticas y Sociales, en 1984 fue reubicada en el Circuito Mario de la Cueva de Ciudad Universitaria. En ese momento, la Facultad contaba con casi seis mil alumnos, 
repartidos en sus cuatro licenciaturas: Ciencias Políticas y Administración Pública, Ciencias de la Comunicación, Sociología y Relaciones Internacionales. Hoy en día, cuenta con más de diez mil estudiantes repartidos en el sistema presencial, abierto y posgrado.

Lo cierto es que el crecimiento de la Facultad de Ciencias Políticas y Sociales fue parcialmente resuelto con la construcción del Edificio "D": cuenta con treinta aulas (de las cuales cinco son de cómputo) y un auditorio para 147 personas. Sin embargo, los alumnos, profesores y personal administrativo de la Facultad, seguimos requiriendo de una estructura adecuada que responda al crecimiento constante de su matrícula y a las tareas de investigación, extensión, vinculación y difusión.

El Edificio "H" ayudará a solventar las exigencias de la nueva licenciatura en Antropología, aprobada por el H. Consejo Universitario el $1^{\circ}$ de julio de 2015 y que iniciará sus actividades en el segundo semestre de 2016; las especializaciones que cuentan con seis programas; los dos posgrados en los que participa la Facultad (Estudios Políticos y Sociales y Estudios Latinoamericanos); la ampliación de la oferta educativa de lenguas extranjeras; la infraestructura para apoyar el crecimiento de las actividades de Educación Continua y Vinculación; la infraestructura para los académicos de tiempo completo (áreas de investigación y trabajo colegiado para los proyectos PAPIIT, PAPIME y CONACYT).

Por todas estas razones, la Facultad de Ciencias Políticas y Sociales solicitó a la Dirección General de Obras y Conservación de la UNAM, diseñara y presupuestara un edificio que se construiría con recursos propios de la Facultad. Conseguir los recursos financieros implicó un enorme esfuerzo de Extensión y Vinculación.

Lo cierto es que la Facultad de Ciencias Políticas y Sociales quiere llegar a una solución consensada y negociada que beneficie y convenza a todos. Por eso no me parece descabellado realizar una intervención artística sobre la fachada del Edificio "H", de tal suerte que lo integre al paisaje.

\section{Fuentes}

Ayala Blanco, Fernando y Mora Velázquez, Salvador (coordinadores), Grupos de poder. La toma de decisiones en un modelo democrático, México, unam, 2010. Ayala Blanco, Fernando y Mora Velázquez, Salvador (coordinadores), Grupos de poder en México. Alcances y perspectivas, México, UnAM, 2011. 
Ayala Blanco, Fernando y Mora Velázquez, Salvador (coordinadores), Tendencias de los grupos de poder en México, México, UNAM, 2012.

Ayala Blanco, Fernando, "Élites, grupos de interés y cabildeo", en Cabildeo y conflicto de intereses, México, Senado de la República-Instituto Belisario Domínguez, 2012.

Bentley, Arthur F., The Process of Government: A Study of Social Pressures, Blomington, Principia Press, 1908.

Duverger, Maurice, Sociología política, Barcelona, Ariel, 1968.

Del Águila, Rafael (ed.), Manual de Ciencia Política, Madrid, Editorial Trotta, 2000.

Gómez Valle, José de Jesús, El cabildeo de los grupos de presión a la Cámara de Diputados en México durante la LVIII Legislatura (2000-2003), Guadalajara, Instituto Electoral del Estado de Jalisco, 2006.

Meynaud, Jean, Los grupos de presión, Buenos Aires, Editorial Eudeba, 1962.

Mills, Wrigth, La élite del poder, México, Fondo de Cultura Económica, 1957.

Mosca, Gaetano, La clase política, México, Fondo de Cultura Económica, 1984.

Pareto, Wilfredo, Forma y equilibrios sociales, Madrid, Alianza Editorial, 1980.

Truman, David, The Governmental Process: Political interests and Public Opinion, Nueva York, Knopf, 1951. 


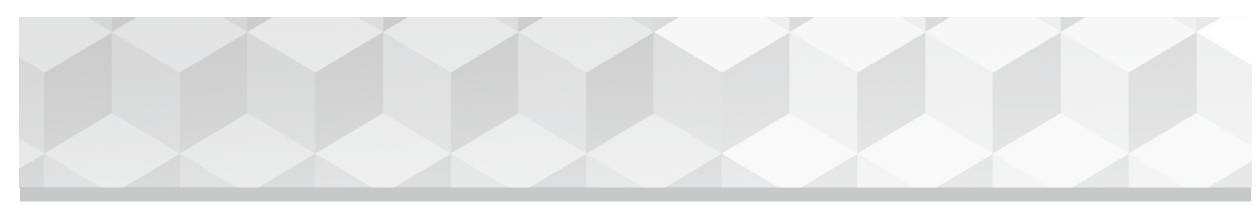

La primera edición electrónica de Presidencialismo y Reforma del Estado: cambios y persistencias en el sistema político Mexicano, fue realizada por la Facultad de Ciencias Políticas y Sociales de la UNAM, se finalizó el 23 de febrero de 2017. La producción de esta obra en PDF interactivo estuvo a cargo de ALDINE, Lázaro Cárdenas núm. 402, entrada 4, depto. 508, Nonoalco Tlatelolco, CP 06900, Ciudad de México.

En su composición se usó el tipo

ITC Berkeley Oldstyle Std de 11/13,2 puntos. Revisión de originales y cuidado de edición: María Eugenia Campos Cázares del Departamento de Publicaciones. Portadilla y maquetación: Marco Antonio Pérez Landaverde. 
